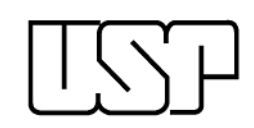

UNIVERSIDADE DE SÃO PAULO

ESCOLA DE COMUNICAÇÃO E ARTES

\title{
RELATOS E REFLEXÕES SOBRE PROCESSOS DE SUBJETIVAÇÃO E PREPARAÇÃO PARA IMPROVISAÇÃO MUSICAL LIVRE
}

PEDRO AZEVEDO SOLLERO 



\title{
RELATOS E REFLEXÕES SOBRE PROCESSOS DE SUBJETIVAÇÃO E PREPARAÇÃO PARA IMPROVISAÇÃO MUSICAL LIVRE
}

\author{
PEDRO AZEVEDO SOLLERO
}

Dissertação apresentada ao Programa de Pós-Graduação em Música da Escola de Comunicação e Artes da Universidade de São Paulo como requisito parcial para a obtenção do título de Mestre em Música. Área de Concentração: Processos de criação musical. Linha de Pesquisa: Sonologia.

Orientador: Rogério Luiz Moraes Costa. 
Autorizo a reprodução e divulgação total ou parcial deste trabalho, por qualquer meio convencional ou eletrônico, para fins de estudo e pesquisa, desde que citada a fonte.

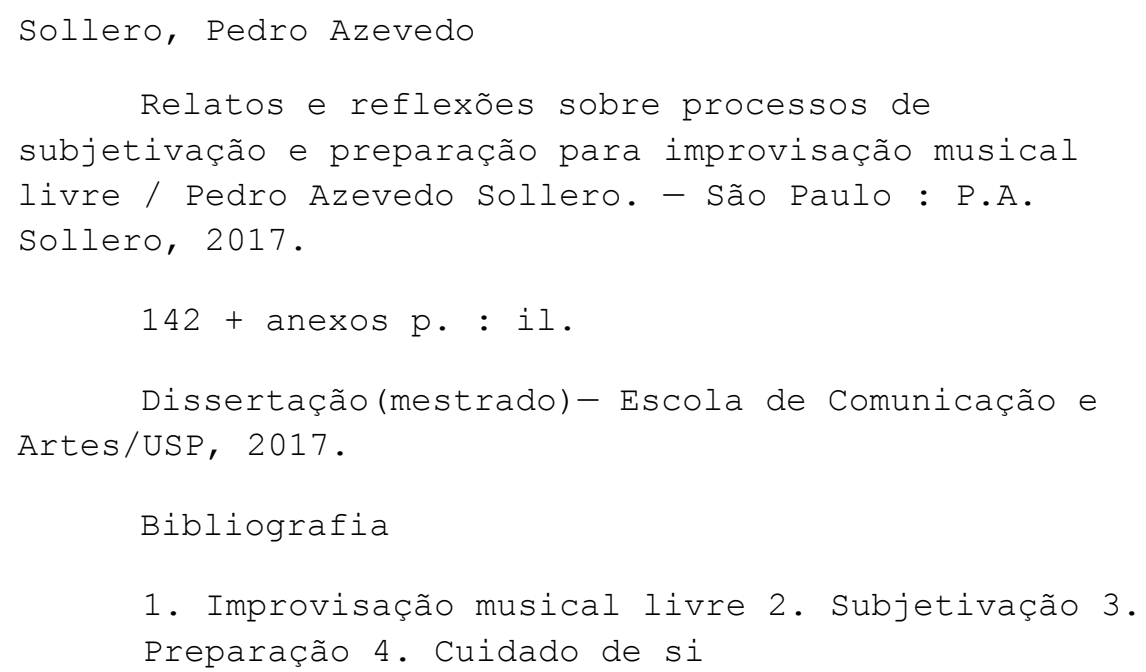


Nome: Pedro Azevedo Sollero

Título: Relatos e reflexões sobre processos de subjetivação e preparação para improvisação musical livre.

Aprovado em:

Presidente da banca:

Prof. Dr.

Instituição:

Julgamento:

Assinatura:

Banca examinadora

Prof. Dr.

Instituição:

Julgamento:

Assinatura:

Prof. Dr.

Instituição:

Julgamento:

Assinatura: 

para os meus amores, Luísa e Aline. 



\section{AGRADECIMENTOS}

Aos meus pais, Celina e Paulo, pelo amor, pelos ensinamentos e pelo apoio que sempre me deram. À minha irmã Teresa e meu irmão André pelo carinho e pelo que também me ensinam até hoje. À minha filha Luísa e minha companheira Aline, que de diversas formas, estão presentes em todas as páginas deste trabalho seja como pensamento, leitura, conversa, sugestão, ou som de ukulele ao fundo. À todas as minhas tias, meus tios, primas e primos, pelo carinho, pelo apoio e pela alegria de sempre. Aos amigos e amigas que de perto, ou de longe, foram e são parte fundamental deste processo. Ao Miguel Antar que ajudou em diversas etapas da pesquisa. À todas as pessoas da Orquestra Errante, é um privilégio tocar e aprender com vocês. Aos amigos e parceiros de caminhada Pedro e Ricardo do grupo Penélopes Nem Sempre Charmosas pela música tão bonita que fazemos. Às pessoas do Coletivo Carmim, este desafio constante é muito engrandecedor e necessário. Ao orientador desta pesquisa, Professor Rogério Costa, pela paciência, atenção e pelas críticas que tanto ajudaram a moldar este trabalho. Às mulheres que se dispuseram a ler esta pesquisa e contribuir para que o assunto dos feminismos fosse tratado adequadamente: Aline Nunes, Flávia Hiroki, Natália Brescansini, Ines Terra, Mariana Carvalho, Lílian Campesato e Tania Neiva. Às bancas de qualificação (Lílian Campesato e Renato Ferracini) e de defesa (Manuel Falleiros e Renato Ferracini), pela leitura atenta e as contribuições fundamentais para a pesquisa. Aos e às colegas do NuSom pelo ambiente de e reflexão que fomentam. Ao corpo docente, funcionários e funcionárias do Programa de Pós-Graduação em Música da ECA-USP pelo cuidado e pelas oportunidades de crescimento e desenvolvimento. 

RESUMO

SOLLERO, Pedro. Relatos e reflexões sobre processos de subjetivação e preparação para improvisação musical livre. 2017. Dissertação (Mestrado em Música). Escola de Comunicação e Artes, Universidade de São Paulo, São Paulo, 2017.

Esta pesquisa reflete sobre processos de preparação para a prática da improvisação musical livre em relação ao conceito de cuidado de si como apresentado por Michel Foucault em sua Hermenêutica do Sujeito. Serão referência também outros estudos sobre subjetividade como de Gilles Deleuze, Felix Guattari e Suely Rolnik. Para colher os relatos sobre os quais se basearam a reflexão, foram realizadas entrevistas com Pauline Oliveros, Susan Alcorn, Chefa Alonso e Rogério Costa. Também foi realizado um experimento com musicistas da Orquestra Errante, e uma revisão bibliográfica dos trabalhos das pessoas entrevistadas e outros autores que falam sobre improvisação livre. Os diferentes caminhos tomados pela pesquisa trouxeram também assuntos como os feminismos e as ciências cognitivas. Estes dois assuntos também perpassam esta pesquisa, embora o primeiro com destaque bem maior. O objetivo deste texto é tratar do desenvolvimento de habilidades 

frequentemente deixadas de lado na formação musical tradicional, porém não menos importantes do que a capacidade de mover os dedos com destreza ou dominar sistemas musicais. Estas habilidades dizem respeito a questões éticas além de estéticas, e possuem paralelos na vida cotidiana. Os resultados indicam caminhos para a reflexão e construção de processos de subjetivação centrados na relação com o outro além do desenvolvimento de si. O texto aqui é dividido em três seções além de prefácio, introdução e conclusões gerais. Na primeira seção são tratados os cruzamentos entre a filosofia estudada por Foucault e publicações no campo da improvisação que falam sobre o ambiente desta prática e processos de preparação. Na segunda seção, dedico-me às entrevistas e ao experimento com a orquestra para desenvolver uma reflexão que relaciona minha própria prática com os relatos colhidos na pesquisa. A terceira seção é dedicada a cruzamentos entre feminismos, cuidado de si e improvisação livre, que se mostraram de grande relevância para o trabalho. As seções podem ser lidas em qualquer ordem ou isoladamente.

Palavras-chave: Improvisação Musical Livre. Subjetividade. Preparação. Cuidado de si. 



\section{ABSTRACT}

SOLLERO, Pedro. Relatos e reflexões sobre processos de subjetivação e preparação para improvisação musical livre. 2017. Dissertação (Mestrado em Música). Escola de Comunicação e Artes, Universidade de São Paulo, São Paulo, 2017.

This research reflects upon processes of preparation for free musical improvisation in relation to the concept of care of the self, as presented by Michel Foucault in the Hermeneutics of the Subject. Other studies in the field of subjectivity such as the works of Gilles Deleuze, Felix Guattari and Suely Rolnik, have also contributed substantially to the present dissertation. In order to collect the different accounts upon which were based the reflections herein, I conducted interviews with improvising musicians Pauline Oliveros, Susan Alcorn, Chefa Alonso and Rogério Costa. I also conducted an experiment with musicians from the improvisation orchestra Orquestra Errante, as well as a bibliographic review of the improvisors interviewed and of other authors in the field of musical improvisation. The way certain events presented themselves, brought about topics such as feminisms and cognitive sciences. Both have received attention, though the latter far less so than the former. The goal of this text is to tend to part of one's musical development which 

is often left aside in traditional musical education, but is no less important than the ability to move fingers skilfully or master musical systems. These abilities are related to ethics as well as aesthetics and thus resonate in daily life. The results suggest paths for reflection and the development of processes of subjectification centred upon the relationship with the other, as much as upon the development of oneself. The main text is divided into three sections besides preface, introduction and final thoughts. In the first section, I deal with intersections between the philosophy studied by Foucault and publications in the field of improvisation which describe the environment of this practice and its processes of preparation. In the second section, I concentrate on the interviews as well as the experiment with the orchestra and attempt to build a reflection about my own practice in relation to those of other musicians who contributed to this research. The third section is dedicated to intersections between feminisms, care of the self and free improvisation, inasmuch as these relations presented themselves greatly relevant to this work. The different sections can be read in any order or individually.

Key-words: Free Musical Improvisation. Subjectivity. Preparation. Care of the self. 



\section{SUMÁRIO}

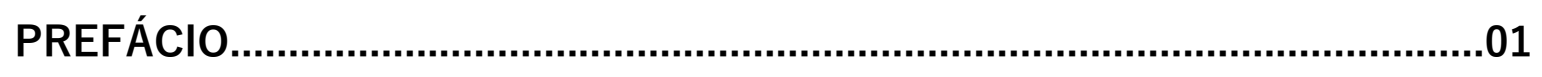

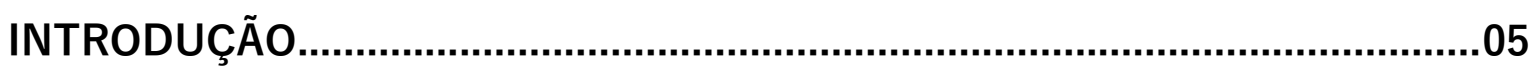

SEÇÃO I - IMPROVISAÇÃO LIVRE E CUIDADO DE SI..................................23

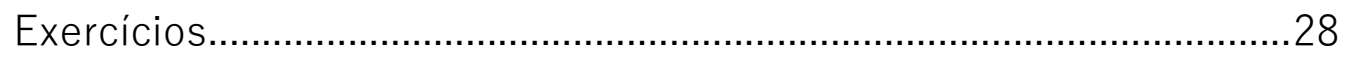

Coragem e domínio de si....................................................................

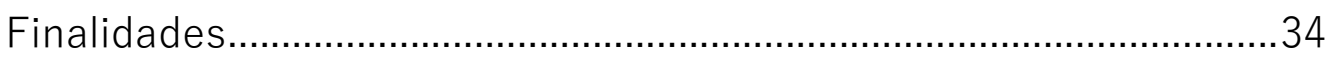

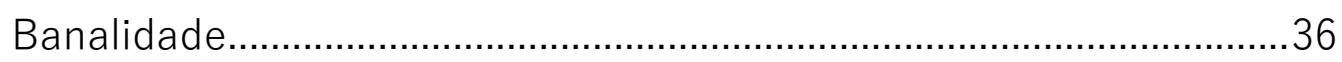

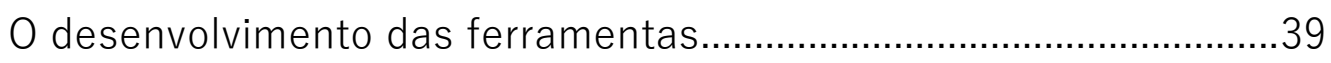

A preparação para o desconhecido...................................................... 45

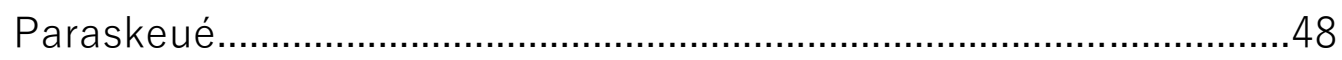

Técnica instrumental, cuidado e conhecimento de si..........................51

Provas, parrhesía e práticas..................................................................56

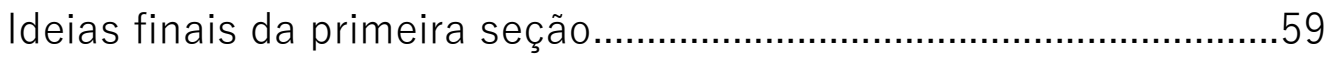



SEÇÃO II - RELATOS E PROCESSOS.......................................................63

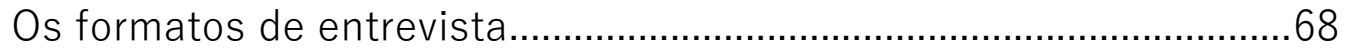

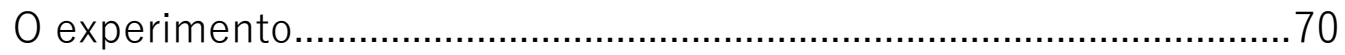

Três intervenções em quatro minutos..................................................73

Só quem tocou pode falar?..................................................................78

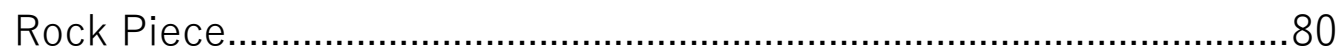

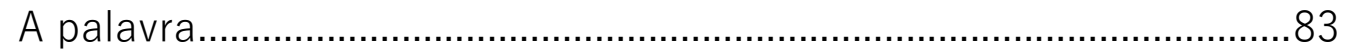

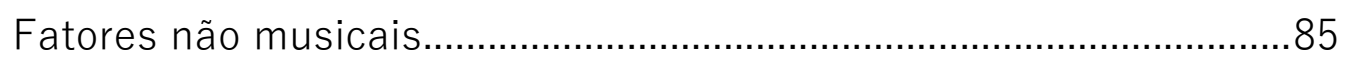

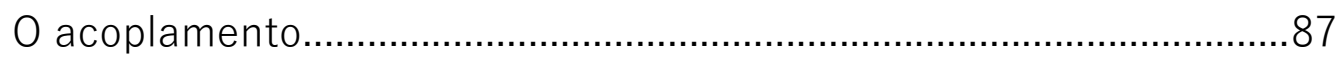

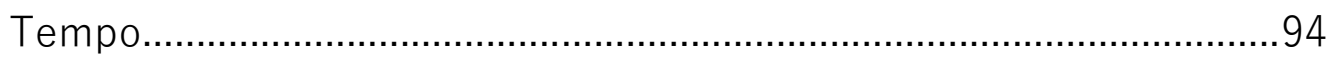

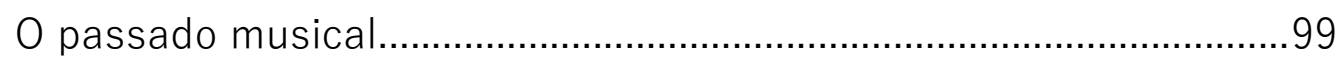

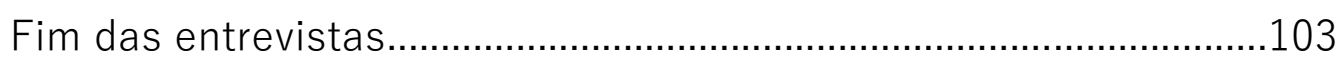

SEÇÃO III - CUIDADOS DE SI, FEMINISMOS E IMPROVISAÇÃO LIVRE...107

As virtudes associadas à música.......................................................114

Pauline Oliveros........................................................................115

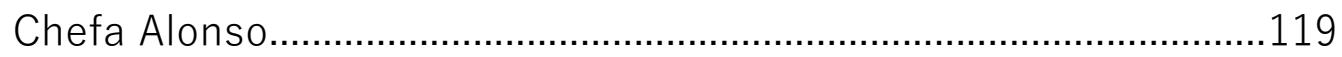

Cuidados de si e feminismos............................................................123

Modelos e referências.........................................................................129

Conclusões da terceira seção..............................................................131

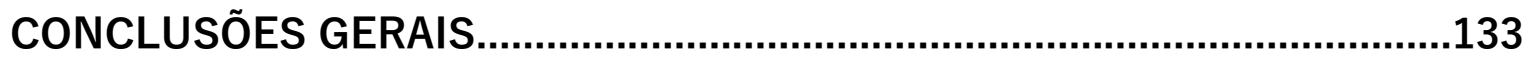

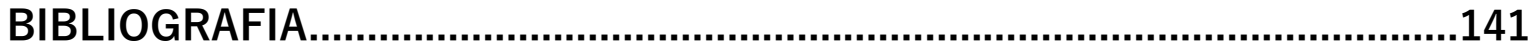

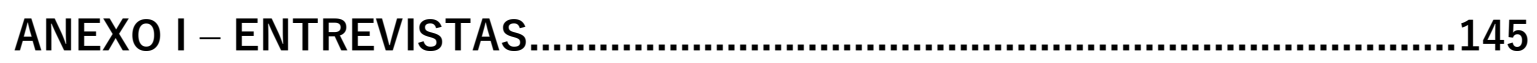





\section{LISTA DE FIGURAS}

Figura 1 - Drawing Hands (1948) de M. C. Escher. 



\section{PREFÁCIO}

Os cruzamentos que encontramos entre algumas das linhas que formam ambientes de improvisação livre e do cuidado de si clássico, como descrito por Michel Foucault, constituem o principal interesse desta pesquisa. Não parece haver nestes cruzamentos, um ponto ideal de partida. As práticas improvisatórias que busco relacionar ao cuidado de si, ora se cruzam com este, ora cruzam-se entre si. Ao mesmo tempo, as ideias de Foucault cruzam-se repetidamente com diferentes partes do material coletado gerando uma multiplicidade de conexões singulares.

Questões, ideias, termos e conceitos que acompanham cada um destes cruzamentos, por vezes requerem certa atenção. Assim, voltam a aparecer no texto, e receber nova luz, conforme parecem relevantes. Houve um esforço por evitar uma abordagem enciclopédica segundo à qual os conceitos seriam apresentados e explicados sequencialmente. Não são os conceitos a parte mais importante deste trabalho e sim a maneira como estes formam possibilidades de ação quando em relação com a prática da improvisação livre. Ao investigar estas ligações, dados foram coletados a partir de leituras, entrevistas, ensaios, reflexões/escrita. Não pretendo hierarquizar aqui estas 
etapas, tampouco acho que se sucedem de qualquer forma lógica. Tanto as referências filosóficas deste trabalho quanto a livre improvisação, são bastante resistentes a unidades centralizadoras e significantes.

Optei então por olhar para certos aspectos destes universos, mas sei que este recorte inevitavelmente excluirá múltiplas compreensões e intenções que habitam os mesmos ambientes improvisatórios. Múltiplas versões de cuidados de si são registradas na história, antes e depois das práticas de subjetivação observadas por Foucault. Estes universos se cruzam em agenciamentos impermanentes, sem ponto único de entrada e em constante transformação.

Os eixos principais que se desenharam nesta pesquisa, e que por isso foram tratados em seções distintas do texto, foram: cruzamentos do cuidado de si com a preparação para improvisação livre; cruzamentos entre feminismos e improvisação livre; relatos a partir de entrevistas e um experimento com musicistas de improvisação de variados ofícios e nacionalidades. Contudo, é quase impossível, e talvez pouco apropriado, impedir que estas seções se cruzem. Tentei escrever cada seção de maneira que cada uma delas fosse o mais independente possível. Com isso, repito ideias, ainda que em geral com diferentes focos. Há certamente um razoável grau de redundância mas acredito que haja também alguma complementaridade entre as partes. Acredito que esta soma pode oferecer a quem porventura decidir ler o texto inteiro, um panorama de relações entre os universos desta pesquisa.

Além da tentativa de um texto mais rizomático, mais adequado ao que estudo, menos linear, há outras dificuldades relativas às ferramentas linguísticas que usarei para falar das pessoas envolvidas nesta pesquisa. A primeira destas dificuldades diz respeito à questão de gênero. A língua portuguesa nos apresenta dificuldades consideráveis para tratar de certas situações. Por motivos que explico na seção que envolve feminismos, minha pesquisa contou com um número significativamente maior de relatos de improvisadoras do que de improvisadores. No entanto, sempre que desejo falar sobre todo o grupo de pessoas entrevistadas, deparo-me com a forma machista do plural e sou impelido a encontrar saídas para cada caso. Este traço da nossa língua passa muitas vezes desapercebido. Talvez por mulheres serem tão frequentemente excluídas de tantos círculos, nos acostumamos à exclusão linguística sem dificuldade. Para nos referirmos a mil homens e uma mulher, usamos artigos, pronomes, substantivos, 
adjetivos... todos do gênero masculino. A maioria masculina deste exemplo possivelmente justificaria o tratamento masculino genérico, porém o cenário inverso, como sabemos, parece ser menos aceitável. Sendo assim, fica claro que a escolha linguística não está relacionada à proporção e sim ao gênero. A questão de gênero dentro da língua portuguesa não é um campo no qual pretendo me aprofundar nesta pesquisa. Há certamente um rico corpo de conhecimento neste sentido, mas o que proponho neste momento é oferecer um relato de como esta questão afetou a minha escrita e quais estratégias busquei para abordá-la da melhor forma que fui capaz em função de uma intenção de não sujeição ou hierarquização. Acuso, portanto, o desconforto de falar sobre uma maioria feminina, como é o caso desta pesquisa, com ferramentas feitas para falar de homens. Algumas tentativas foram feitas no sentido de amenizar o efeito deste vício social que habita a nossa estrutura linguística. A palavra improvisadores, por exemplo, foi muitas vezes substituída por musicistas de improvisação, ou improvisadoras e improvisadores (procurando variar a ordem). Substituições deste tipo foram feitas em diversos lugares do texto, porém há trechos em que por distração, vestígios conformistas, desejo de variação nos termos, ou falta de criatividade para achar uma saída, recorri, contrariado quando percebi, a este uso do plural. Acredito que para olhos atentos a este tipo de questão isso fique evidente. Não é do interesse do pesquisador que a forma da pesquisa reproduza valores negados em seu conteúdo. Ainda que a meta não tenha sido atingida todas as vezes, espero que possa aproveitar este material para além das imperfeições no tratamento de uma questão que é nova em uma escrita em constante desenvolvimento.

Outra questão relevante mora nas escolhas feitas no decorrer do texto entre primeira pessoa do singular ou plural. A implicação do pesquisador em um trabalho como este é inevitável. Haverá momentos no texto em que serão descritas minhas experiências, reflexões ou ações individuais. Nestes casos será usada a primeira pessoa do singular. Há também ideias que habitam as bibliografias e reflexões compartilhadas no processo de orientação acadêmica que contaminaram fortemente toda a pesquisa na maneira em que está foi executada e descrita. Neste caso, usarei o plural. Fora o prefácio e a introdução, o corpo principal do trabalho se divide em três seções que podem ser lidas em qualquer ordem ou isoladamente. Todas elas dizem respeito ao tema principal deste trabalho, ou seja, processos de preparação para a improvisação livre, por diferentes ângulos. A ordem das seções neste documento foi sorteada para reunir todas em um só 
documento. Contudo para possibilitar a leitura das partes separadas, cada seção possui um ou dois parágrafos introdutórios e uma breve conclusão. Assim, as conclusões do trabalho também estão distribuídas entre as três seções. A seguir, na introdução, explicarei melhor do que se trata a pesquisa, quais foram suas motivações e a quem ela talvez possa servir. 


\section{INTRODUÇÃO}

Esta pesquisa partiu de uma questão bastante prática. Uma busca por ferramentas que ajudassem na realização do meu trabalho. Sou músico e minha principal atuação se dá em um território que há algumas décadas vem sendo chamado de improvisação livre. Este movimento musical, grosso modo, é uma prática que surge na segunda metade do século XX, no qual toda a música é criada na hora pelas pessoas que a tocam. Reflexões históricas, filosóficas e pedagógicas a respeito deste movimento podem ser encontradas no livro de Derek Bailey Improvisation - its nature and practice in music, no livro Improvisación Libre - composición en movimiento de Chefa Alonso, e mais recentemente em Música Errante de Rogério Costa.

Estes autores e autora apontam que, diferente de outras músicas que também têm na improvisação parte fundamental de sua prática, a improvisação livre, em geral, procura não se submeter a gêneros ou estilos específicos, ainda que elementos de idiomas ocasionalmente surjam transformados como paródia, colagem, citação... Chefa Alonso, pesquisadora e musicista de improvisação livre, foi uma das entrevistadas deste trabalho e falaremos mais sobre suas ideias nas páginas que seguem. Rogério Costa, 
orientador desta pesquisa, também ofereceu seu relato que — junto com as ressonâncias do processo de orientação acadêmica e minha participação como músico na Orquestra Errante $^{1}$, na qual Costa atua como músico e coordenador - ajudará a compor esta reflexão.

É comum também à improvisação livre uma escuta mais atenta ao som, do que à ideia de nota e as maneiras como este conceito foi trabalhado na história da música, como em motivos, figuras, melodias, acordes, etc. Todas estas e infinitas outras maneiras de pensar e organizar os sons podem existir nesta forma de fazer música, contudo são apenas mais uma possibilidade e não o chão sobre o qual deve se fundar a criação musical. Cada musicista deverá decidir como relacionar-se com estas possibilidades baseado em sua bagagem e sua percepção do momento. No entanto a nãoobrigatoriedade dos idiomas que compõe boa parte da formação de musicistas profissionais, permite que certos contextos de improvisação livre sejam abertos também a pessoas com outras ocupações e formações profissionais, e que a voz destas pessoas se insira com a mesma legitimidade de musicistas com décadas de experiência e treinamento. Nestes grupos, frequentemente, não só NÃO se parte de qualquer convenção musical abstrata - como notas, acordes, arpegios, melodias, padrões rítmicos, gramáticas e vocabulários musicais, etc. - mas existe reiteradamente a ideia de que fragmentos e referências idiomáticas, para que possam se integrar nesse fluxo improvisatório, devem ser moldados em relação ao fluxo inédito que se constrói no momento de cada improvisação. Para isso é necessário ser capaz de agir na contingência, cada participante em relação ao outro ou outra, sem sujeição de um discurso pelo outro.

Esta forma musical surgiu na Europa na década de 1960 e traz com frequência, forte influência de pensamentos musicais do século XX e XXI que abrem mão das convenções que eu citei e focam em outros modos de escuta e interação sonora menos específicos e com membranas mais porosas, capazes de dar conta desta máquina imanente com regras e funcionamentos sempre novos. Timbre, sonoridade, textura e gesto ganham lugar notável nestes processos de criação coletiva. As ideias de escuta propostas por Pierre Schaeffer, John Cage, Dennis Smalley são habituais nestes círculos de

\footnotetext{
${ }^{1}$ A Orquestra Errante é um grupo de prática e pesquisa em improvisação livre, sediado no departamento de música da ECA-USP, do qual faço parte. O grupo é coordenado pelo orientador desta pesquisa, Professor Rogério Costa. Para mais informações sobre a história e a prática deste grupo podem ser encontradas no livro lançado em 2016 por Costa, chamado Música Errante. Neste livro, o autor também discorre sobre diversos aspectos relativos ao ambiente da improvisação livre.
} 
improvisação. Ainda que todos estes nomes estejam inegavelmente ligados à tradição musical eurocêntrica — ou eurológica como escreve Lewis ${ }^{2}$ — a inclusão de pessoas sem formação musical, o caráter descentralizado da improvisação livre (IL), e a abertura para outras formas de fazer e pensar música trazem grande diversidade a esta prática musical. Os pré-requisitos dos idiomas musicais, que impossibilitariam a participação de muitas pessoas, são substituídos, não por sistemas fechados, mas por ferramentas que devem ajudar no processo de criação coletiva. Embora possa servir de estímulo para quem quiser, não é necessário decorar tabelas de tipologias de objetos sonoros, ou ler as reflexões de Cage sobre o silêncio, ou saber a diferença entre espaço espectral e espaço perspectivo. No entanto, estas reflexões, quando tomadas como ferramentas disparadoras de processos criativos, podem mostrar-se como contribuições preciosas no sentido de facilitar a interação entre musicistas das mais variadas formações.

A questão da escuta, evidentemente indispensável neste tipo de processo, é o centro do trabalho da improvisadora e compositora Pauline Oliveros que também contribuiu com seus relatos para esta pesquisa. Criadora do termo Deep Listening, a musicista é parte importante da história da música improvisada e referência fundamental em estudos sobre modos de escuta, assunto que, como mostram COX e $\mathrm{WARNER}^{3}$, recebeu atenção inédita no último século e certamente possui posição central na improvisação livre. A autora também busca, com ajuda das ciências cognitivas, compreender os diferentes processos mentais que determinam velocidades de reação dentro de uma improvisação.

Susan Alcorn, artista associada ao Deep Listening Institute, é compositora e improvisadora e também concedeu uma generosa entrevista para este trabalho. Seu instrumento é pedal steel guitar, embora estenda consideravelmente suas possibilidades técnicas e sonoras. Trabalhou com Pauline Oliveros além de inúmeros nomes da improvisação livre como Fred Frith, Magie Nicols e Evan Parker, entre outros. Alcorn possui também trabalhos como instrumentista de música escrita. Sua ampla formação musical acolhe de Olivier Messiaen a Muddy Waters e seu relato oferece importantes contribuições em relação à preparação técnica e musical para a improvisação além de reflexões sobre a ética deste ofício.

\footnotetext{
${ }^{2}$ LEWIS, 2002.

${ }^{3}$ COX e WARNER, 2004.
} 
Rogério Costa, que participa desta pesquisa por diversos ângulos, é orientador desta investigação, coordenador e musicista na Orquestra Errante, da qual faço parte, e também foi entrevistado. Seu trabalho faz referência a uma escuta centrada sobre o som, como a escuta reduzida de Schaeffer, porém com influências de autores como Denis Smalley e Alain Savouret. Além deste foco mais próximo ao paradigma de som do que de nota, Costa propõe, em artigo de 2010, estratégias pedagógicas baseadas nas ideias do compositor Brian Ferneyhough sobre figura, gesto e textura. Em seu livro Música Errante, o autor inclusive faz referência ao uso de idiomas como o blues para uma primeira abordagem em oficinas de improvisação, quando parece adequado. Suas ideias envolvem uma compreensão da improvisação livre segundo a filosofia de Gilles Deleuze e Felix Guattari, que são referências teóricas para esta pesquisa, bem como para a recente publicação de Marcel Cobussen intitulada The Field of Musical Improvisation ${ }^{4}$. Cobussen, como Costa, vê na improvisação um fluxo de agenciamentos temporários de múltiplas linhas de força em eterno movimento de estratificação e desestratificação.

A visão deleuziana de Costa junto com as ideias de Cobussen que compreendem a improvisação como um sistema complexo, dinâmico e não-linear, serão base para boa parte do pensamento que se desenvolverá neste texto. A obra citada de Marcel Cobussen também será referência na maneira de olhar para os processos improvisatórios em questão, ao compreendê-los segundo a ideia de singularidade. $\mathrm{O}$ autor usa este termo para descrever a inadequação das generalizações no estudo das relações e múltiplos agenciamentos complexos que se dão na improvisação.

Para Cobussen, cada improvisação deve ser tratada dentro de sua complexidade e singularidade. Em uma aproximação das ideias de Deleuze, o autor afirma “implícito na filosofia de Deleuze está um aviso contra o reducionismo, contra generalizações, contra modelos teóricos que buscam simplificar e desembaraçar a realidade".

A ideia de singularidade também é formulada por Felix Guattari e Suely Rolnik em Cartografias do desejo com um enfoque um pouco diferente. Guattari e Rolnik compreendem que "trata-se dos movimentos de protesto do inconsciente contra a subjetividade capitalística, através da afirmação de outras maneiras de ser, outras

\footnotetext{
${ }^{4}$ COBUSSEN, 2017.
} 
sensibilidades, outra percepção" (GUATTARI e ROLNIK, 1996:45). Ambas as compreensões deste termo possuem ressonâncias no presente trabalho. Esta noção será aprofundada no decorrer desta dissertação.

Costa também reflete, em sua produção acadêmica, sobre estudos que relacionam a música improvisada e as ciências cognitivas, campo no qual sua principal referência é o trabalho de Jeff Pressing. Neste sentido, Costa busca descrever ferramentas e recursos disponíveis para musicistas de improvisação a partir de modelos teóricos desenvolvidos por Pressing e outros autores. Pauline Oliveros também se remete a fontes das neurociências e ciências cognitivas para investigar tempos de resposta na improvisação. Seu interesse é pelo período entre a ideia musical e sua conversão em ondas sonoras. Na segunda seção do texto falarei mais sobre estas relações que envolvem a escolha de materiais e procedimentos, e as habilidades que permitem que estes elementos sejam colocados em jogo.

Quanto à seleção dos materiais e meios de emissão sonora, todas as pessoas com quem conversei nesta pesquisa fazem amplo uso de técnicas estendidas em buscas por novas sonoridades. Explorar sons externos à palheta tradicional de possibilidades técnicas e sonoras dos instrumentos é prática comum na música da segunda metade do século XX e, como mostram Padovani e Ferraz em artigo de $2011^{5}$. Os autores mostram que o que chamamos de técnicas estendidas na realidade fazem parte de um processo bem mais antigo que envolve a própria evolução dos instrumentos musicais no qual a técnica estendida de hoje se torna a técnica tradicional de amanhã. No mencionado artigo, os autores também propõem uma acepção mais ampla do termo para incluir o uso de computadores que há alguns anos, afirmam, integram de maneira crescente as práticas musicais.

Estas extensões muitas vezes cumprem um objetivo de deslocar a escuta para outros aspectos da música para além das notas e suas relações. Na improvisação livre é comum que instrumentistas se interessem por novas maneiras de fazer vibrar o instrumento, assim gerando novos sons, frequentemente descobertos por acaso em um processo exploratório que envolve uma relação de retroalimentação entre instrumentista e instrumento - como é o caso de Chefa Alonso e Susan Alcorn - ou

\footnotetext{
${ }^{5}$ PADOVANI e FERRA, 2012.
} 
por meios de misturas entre explorações físicas e processamentos digitais - como em Pauline Oliveros e Rogério Costa.

Entre discursos recorrentes a respeito da improvisação livre também encontramos questões que certamente extrapolam o campo musical, como as relativas à interação humana e à relação do sujeito consigo mesmo. Todos os relatos colhidos nesta pesquisa parecem evidenciar, cada um à sua maneira, a importância destes discursos. Questões musicais se entrelaçam com democracia, anarquismos, subjetivação, etc.

Uma questão aparentemente não musical que se mostrou relevante no decorrer da pesquisa foi a relação, ou relações, das práticas de subjetivação que acredito possuírem ressonâncias na improvisação livre, com as mulheres e os feminismos. Apontarei, na seção cuidados de si, feminismos e improvisação livre, cruzamentos entre discursos de pesquisadoras feministas foucaultianas, principalmente a historiadora Margareth Rago e a filósofa Margaret McLaren, e discursos encontrados na literatura sobre IL.

É importante ressaltar que este não é propriamente um trabalho sobre gênero, e por isso não pode oferecer o aprofundamento que algumas das questões levantadas demandam. Ademais, é inevitável que minha escrita seja contaminada pelo fato de que sou homem. Neste processo de contaminação, fatos importantes podem escapar à atenção. Portanto, para amenizar este processo pedi ajuda a algumas mulheres artistas, feministas e pesquisadoras que gentilmente leram o tex to e ajudaram-me a trazelo ao formato atual.

Os feminismos cruzam-se com a improvisação livre em inúmeros pontos: a não sujeição de uma voz por outra na criação do discurso coletivo, os processos de subjetivação e cuidados de si, a relação dinâmica destes processos na sociedade e em práticas não diretamente ligadas às lutas feministas ou à improvisação. Cada uma destas questões pode ser tratada de variadas formas. Neste trabalho concentrei-me em algumas relações com a improvisação livre sob a óptica do cuidado de si.

Falar sobre feminismos surgiu como necessidade de adaptação da pesquisa às realidades encontradas, como explicarei mais à frente. Felizmente há um número crescente de trabalhos acadêmicos que tratam de questões de gênero dentro e fora da música, no Brasil e no mundo. Ainda que para objetivos distantes, parece haver um 
caminhar que ganha força. Não tenho interesse em fazer qualquer tipo de generalização ou ensinar alguém sobre feminismos. Tenho muito mais a aprender daqui do meu lugar coberto de privilégios e, neste sentido, busquei apenas me informar e refletir sobre como estas questões estão relacionadas ao meu trabalho e a todo o resto da minha vida.

Relações de poder são um fator decisivo em uma execução musical. Além das relações intersubjetivas estabelecidas entre humanos, Cobussen vale-se das ideias do etnomusicólogo Bruno Nettl para falar em atuantes não humanos sobre processos de improvisação musical que acredito que podem ajudar a pensar sobre outras relações dentro da música. O poder da partitura ou a obrigatoriedade do idioma, além de oferecerem chão firme e segurança de uma boa execução, inibem algumas outras possibilidades. Uma vez removidos estes fatores podemos olhar para outros atuantes dos processos em questão.

A ausência de qualquer convenção de material ou sonoridade que conduza o processo criativo em livre improvisação faz com que seja necessário, nesta forma de fazer música, o acordo $^{6}$ sonoro "quase" imediato entre as múltiplas vozes. $O$ ajuste deste "quase" pode ser pensado como parte do jogo da improvisação, alargado ou encurtado, oferecendo configurações inéditas, gerando variedade, interesse, movimento, etc. A diminuição do tempo destes ajustes, para que a coordenação das partes do todo seja mais ágil, também é algo que pode ser treinado por meio de exercícios.

Além desta abordagem mais centrada sobre a mecânica que um grupo deve desenvolver enquanto corpo improvisador, habilidades interpessoais são diretamente relacionadas ao processo de criação e trabalhadas musicalmente. Estes exercícios, que podemos encontrar nas entrevistas e na produção bibliográfica das pessoas entrevistadas, preparam o sujeito para a improvisação musical livre e para a vida em coletivo. Parâmetros musicais são frequentemente trabalhados pelo grupo, a partir de exercícios que envolvem um desenvolvimento tanto ético quanto estético. A maneira como ideias musicais são colocadas em prática em tempo real — e a partir da negociação imanente dos diferentes discursos musicais - demanda que musicistas de certos

\footnotetext{
${ }^{6} \mathrm{O}$ que chamo aqui de acordo é algo bastante difícil de definir. Refere-se a uma sensação subjetiva de um momento em que as diferentes buscas de cada instrumentista chegam a algo com um sentido de um todo em relação ao grupo. Uma sensação de encontro, de encaixe. Um momento intenso de grande concentração e escuta. Esta situação musical, na maneira como vejo, não precisa necessariamente centrar-se sobre uma ideia musical. Uma multiplicidade polifônica também pode ser vista, ouvida, sentida como um acordo.
} 
ambientes de IL se comportem em relação ao grupo segundo pressupostos éticos que se mostram nos discursos de diversos autores e autoras dentro deste campo. Rogério Costa em seu livro Música Errante reflete sobre a dimensão assumida pelo silêncio em processos de improvisação que visam extrapolar limites e constantes. Em seguida, o autor aponta:

Outras linhas de força extramusicais importantes para o sucesso dessa proposta são as qualidades necessárias para o convívio - que requer uma dose de disciplina individual - entre os músicos: humildade, generosidade, curiosidade, sensibilidade e paciência. Trata-se de uma ética coletiva. Assim se constrói "não uma linguagem conscientemente articulada, mas, passo a passo - cada passo por uma pessoa diferente - uma coisa simbiótica. $\mathrm{O}$ todo excede a soma das partes individuais. (COSTA, 2016:11)

Em uma entrevista sobre o ensino da improvisação contemporânea, o guitarrista Fred Frith relata:

No geral, as qualidades que fazem um bom improvisador não são diferentes das que eu aprecio nos meus amigos: saber escutar, atenção às pessoas à sua volta, "estar lá" quando for necessário, mas também saber quando dar um passo para trás, saber quando ser solidário e quando ser assertivo, quando sua opinião é válida e quando se deve somente ir com o fluxo, quando insistir! Paciência. Tolerância. Abertura. (CHAN, 2007:2) ${ }^{7}$

Chefa Alonso, em seu livro Improvisación Libre: la composición en movimiento, afirma: "a improvisação põe em jogo de forma poética, modos de relacionarse com o mundo e com os demais" (Alonso; 2008:5) ${ }^{8}$

Esta recorrência não é por acaso. A presente investigação se interessa pelas potências da improvisação livre como prática de subjetivação com fins éticos bastante claros, que não podem ser dissociados do seu resultado estético sonoro. Buscase frequentemente formas de existência distintas do que Guattari chama de subjetividade serializada do capitalismo mundial integrado (CMI).

Parece relevante pensarmos sobre novos modos de existir em um mundo em crise no qual a interação humana flerta com rumos bastante perigosos e reproduz endemicamente valores contrários aos que encontramos na improvisação livre. Neste sentido, acredito que estejamos de acordo com Guattari e Rolnik:

O que caracteriza os novos movimentos sociais não é somente uma resistência contra esse processo geral de serialização da subjetividade, mas também a tentativa de produzir modos de subjetividade originais e singulares, processos de singularização

\footnotetext{
${ }^{7}$ Tradução minha.

${ }^{8}$ Idem.
} 
subjetiva. (GUATTARI e ROLNIK, 1996:45)

A improvisação livre, portanto, apresenta-se como um terreno bastante fértil para estas reflexões, além de um espaço em que ideias de interação ganham movimento e são experimentadas sonoramente nos corpos que criam juntos. São, portanto, necessárias para a IL, as mesmas ferramentas para resolução de problemas da vida cotidiana. Os constantes e múltiplos cruzamentos entre a vida dentro e fora da IL nos instigam a pensar sobre suas relações com o cuidado de si. A IL é uma forma de cuidado de si e ensaio para a vida? Ou o cuidado de si, como organização de diversos aspectos da vida do ou da musicista, compõe a preparação para a IL? Esta disposição dualista pode ser perigosa se esquecermos que ambas são verdade. Em relação à questão de se o sujeito faz, ou é feito pela improvisação - no sentido que o fluxo improvisatório em devir, por meio da escuta de cada musicista, determina os atos das pessoas que o criam, além de deixar vestígios que acompanham cada musicista em sua vida longe do grupo - o professor Renato Ferracini, na ocasião do meu exame de qualificação na Universidade de São Paulo, ofereceu uma imagem que, acredito, ilustra bem este tipo de processo: as mãos de Escher que surgem enquanto desenham uma à outra.

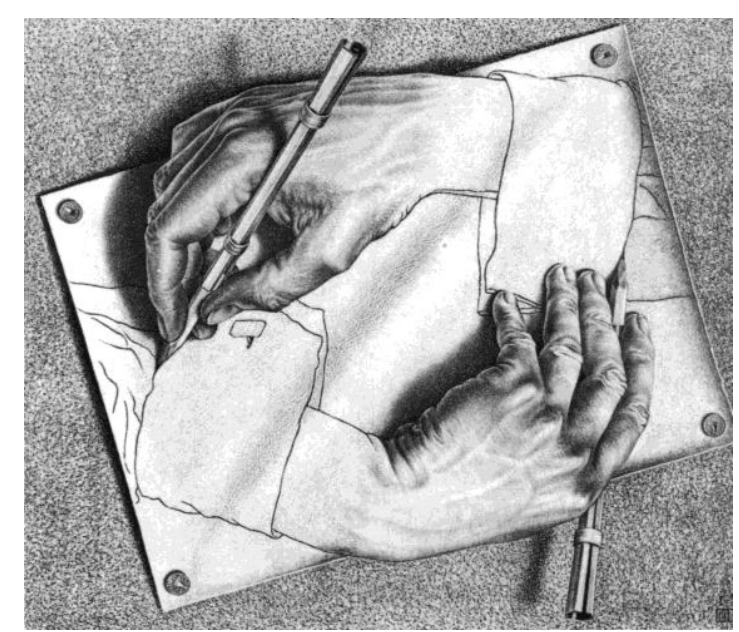

Figura 1 - Drawing Hands (1948) de M. C. Escher. Fonte: Escher (1948)

É com os olhos e os ouvidos voltados para esta relação de retroalimentação que acredito que o cuidado de si, com seu caráter ético e social, seu cuidado do outro, é ferramenta fundamental para a integração da IL dentro do contexto do qual ela faz parte, e para que se possa observar as ressonâncias, nesse contexto, das habilidades intersubjetivas que ela põe em jogo. Acredito que a IL se consolida como ambiente heterotópico — ou seja, que propõe alternativas de existência - a partir do 
momento em que o sujeito que improvisa se coloca em relação com seu entorno e aplicase em desenvolver-se nas habilidades requeridas para este jogo. Insere-se assim em uma heterotopia maior $^{9}$ e alimenta-se dela ao mesmo tempo em que lhe serve de alimento.

Em um mundo que se pretende bélico e exato, parece relevante que pesquisas acadêmicas e práticas como a improvisação livre se voltem para a busca de novas formas de olhar para si que contrariem estas pretensões. É necessário, no entanto, estarmos atentos. Esta luta se dá em um ambiente bastante delicado, dentro de cada musicista e sua multiplicidade de linhas de força. Olhar para si nunca é fácil e as tentações das subjetividades serializadas são consideráveis. É central no presente trabalho, escapar o máximo que conseguir, de pensamentos maniqueístas que poderiam colocar o musicista de improvisação em lugar diferenciado capaz de compreender e resolver as questões do mundo. Observar este ou aquele comportamento que consideramos inadequado no outro é fácil, porém simplifica artificialmente a questão das relações sociais. Um músico competente, com ótimas intenções e aparentes convergências éticas com o grupo, pode passar por cima dos outros com seu instrumento sem qualquer pudor ou tentativa de escuta de detalhes que desaparecem sob sua potência sonora. Um músico ao lado pode perceber e se incomodar, e logo em seguida agir da mesma forma que seu colega sem sequer notar. Ambos podem fazer o contrário no ensaio ou na música seguinte.

Neste sentido, considerar a IL dentro de um contexto de práticas de liberdade capazes de transformação social, deve considerar a complexidade do sujeito que ocupa este campo de tensões. A revolução molecular que Felix Guattari descreve na citação a seguir, dá-se no campo da construção de subjetividades onde a IL se aponta como mais uma ferramenta.

Para Guattari:

A problemática do questionamento do sistema capitalístico não é mais do domínio exclusivo das lutas políticas e sociais em grande escala, ou da afirmação da classe operária. Ela diz respeito também àquilo que tentei agrupar sob o nome de revolução molecular, cujos inimigos ou antagonistas não podem ser classificados em rubricas claramente delimitadas. Há uma relação de complementaridade e de segmentaridade, que faz com que as vezes sejamos, simultaneamente, aliados e inimigos de alguém. (GUATTARI e ROLNIK, 1996:48)

\footnotetext{
${ }^{9}$ Refiro-me aqui à criação de subjetividades alternativas à hegemônica proposta pelo CMI, como descrevem Guattari e Rolnik em Cartografias do desejo. O autor e a autora fazem uso do termo revolução molecular para designar isto que defino como uma heterotopia na qual se insere a IL.
} 
A improvisação tem se mostrado uma tendência importante nos séculos XX e XXI, encerrando na música - localizada por George Lewis ${ }^{10}$ como de tradição eurológica - um hiato improvisacional de quase 150 anos. Apesar da curta duração em relação aos milhares de anos de música ubiquamente improvisada descritos por Derek Bailey em seu livro Improvisation: its nature and practice in music, este pequeno hiato acusado por Lewis, parece gerar por vezes a impressão equivocada de que a improvisação não é parte fundamental de praticamente toda produção musical da história. Marcel Cobussen, no livro já citado, oferece uma gama de musicistas, sociólogos e musicólogos que defendem que, em diferentes graus e de variadas formas, a improvisação está presente, de fato, em qualquer criação musical.

Tive em minha formação, aulas de harmonia, rítmica, solfejo, técnica, leitura, improvisação idiomática... como é comum na formação de tantos e tantas musicistas. Tirei solos, decorei padrões mecânicos e de relação, flertei com sistemas, juntei uma espécie de bagagem de sons, ideias, processos, experiências. Durante a graduação em Música Popular na Universidade Estadual de Campinas, comecei a me interessar por outras formas de pensar sobre determinações e seus limites e opostos dentro de músicas improvisadas que já faziam parte da minha prática.

Buscava outras formas de improvisar dentro de contextos próximos ao jazz, que não o famoso "tema-solos-tema". Conheci o trabalho de Cage e outras formas de música aberta. Em seguida, os seminários de Improvisação Generativa, com Alexandros Markeas, realizados na Unicamp em parceria com o Conservatório de Paris, foram determinantes na expansão do que compreendia como improvisação. Junto com essa expansão de possibilidades sonoras mostrava-se de maneira crescente a inadequação de algumas das ferramentas e recursos que havia acumulado até então.

Algumas práticas, como certos exercícios de técnicas, padrões mecânicos e relações harmônico-melódicas, mais dificultavam do que ajudavam em certos contextos de improvisação. Sentia que tudo o que preparava saia pela janela ao primeiro som do grupo. A tentativa de forçar o material ou procedimento estudado para dentro de uma improvisação coletiva era quase sempre desastrosa. Outros sons pediam

\footnotetext{
${ }^{10}$ Em artigo intitulado Improvised Music After 1950: Afrological and Eurological Perspectives, Lewis relaciona o fim deste hiato na tradição eurológica à presença de manifestações de tradição afrológica e improvisatória como o Jazz.
} 
passagem e nos dias bons o material preparado era completamente esquecido. A escuta levava para outros caminhos. O que restava da preparação se não os vícios ${ }^{11}$ ? Perguntava. A imprevisibilidade da improvisação livre faz com que materiais e procedimentos pouco flexíveis tenham dificuldade para encontrar espaço. Entre o dilema de ignorar a escuta ou de esquecer o que foi preparado, há a possibilidade de compreender que a preparação para improvisação também forma mais do que informa.

Assim, a não utilização na performance, dos materiais e processos desenvolvidos durante a preparação não é frustrante. É apenas uma adaptação natural e rápida ao contexto inédito que se cria. Esta sensação de preparar e não usar, também é relatada por Chefa Alonso e Susan Alcorn que compreendem a preparação de maneira aberta, porosa, capaz de relacionar-se com o instante único da improvisação e todos os fatores humanos e não-humanos que o configuram. Portanto não se trata de não se preparar, mas de saber que o que vai acontecer na improvisação provavelmente será algo singular, não necessariamente relacionado ao que fez parte da preparação.

Parecia necessário repensar as práticas que compunham a minha preparação no sentido de torná-las mais adaptáveis e relevantes. Remover aquilo que gerava caminhos mentais viciados e confundia a escuta. Achar meios de exercitar outros tipos de sons e relações sonoras. É importante mencionar que estes objetivos não são do tipo que um dia são alcançados e tudo se resolve. São processos dinâmicos. O sujeito nunca está pronto.

Alguns anos depois, no início desta pesquisa de mestrado, pretendia refletir sobre certos aspectos da preparação individual para a improvisação musical livre. O que musicistas faziam fora do ensaio que os ajudava a improvisar? Caminhos que pudessem ser tomados sozinhos. Rotinas, ideias, práticas... como preparar-se para o desconhecido?

Esta pergunta, cuja resposta frequentemente envolve o domínio de certos idiomas musicais, pode ser compreendida de maneira mais ampla se levarmos em consideração outros fatores que influenciam a nossa capacidade de agir no momento

\footnotetext{
${ }^{11}$ Uso esta palavra em um sentido mais amplo do que a compreensão comum deste termo em ambientes de ensino musical. Não me refiro a hábitos e procedimentos técnicos assimilados de maneira diferente daquela tida como correta de se produzir determinados sons. Falo aqui de outras recorrências como usar sempre os mesmos materiais, procedimentos, formas de interação, etc.
} 
presente. Fatores como as habilidades descritas por Chefa Alonso em seu livro Enseñanza y Aprendizaje de la Improvisación livre, isto é, "escuta, concentração, interação, confiança, decisão, energia, memória, risco, intenção..." (ALONSO, 2014:20) ${ }^{12}$ Ao abordá-las, esbarramos em questões sobre outras atividades improvisadas, que são bastante antigas na história do pensamento.

Estas habilidades das quais falam Alonso, Costa e Frith, como sabemos, são ferramentas da vida cotidiana onde as coisas não acontecem de acordo com partituras claras e sim de acordo com uma multiplicidade de fatores e pequenas decisões tomadas a todo instante se relacionando e interinfluenciando em sistemas complexos. Para tratar este amplo problema, veremos aqui constantemente ideias do universo da música e da filosofia. O livro já mencionado de Marcel Cobussen será referência fundamental no sentido que aborda por diferentes ângulos a questão da complexidade na improvisação livre além da singularidade que o autor propõe para olharmos para processos improvisatórios.

Em um dos primeiros abalos ao meu plano inicial de pesquisa, dei-me conta de que a ênfase que dava ao caráter individual da preparação para improvisar, deixava de lado parte crucial dos processos envolvidos. Referências, tanto na literatura musical quanto nas outras áreas do conhecimento, apontam para a relação com o outro como parte central dos processos de desenvolvimento e preparação para o ato improvisado. A improvisação se dá, de fato, no espaço entre as pessoas.

Saber, e praticar, criar com o outro é tão difícil quanto fundamental e pode nos remeter a diversas outras situações sociais. Todos os relatos desta pesquisa são de musicistas que possuem trabalhos solo e com grupos de tamanhos variados, e ressaltam a relevância da prática em grupo para o desenvolvimento da improvisação livre, além de comentarem a relação destes processos com outros externos à música. Este caráter coletivo das práticas de preparação e a relação destas com práticas não diretamente musicais também é central nas referências filosóficas deste trabalho.

A principal referência neste sentido de compreender a preparação dentro de um conjunto de práticas que existe em relação a toda vida do sujeito e não somente ao ato de improvisar música — ou exercer qualquer que seja o ofício em questão

\footnotetext{
12 Tradução minha.
} 
— foi o trabalho de Michel Foucault em seu curso de 1982 no Collège de France, mais tarde organizado em livro intitulado Hermenêutica do Sujeito. Neste curso, Foucault apresenta o conceito de cuidado de si como compreendido e praticado em certo período da filosofia clássica. O autor descreve processos e práticas da ascese filosófica e da preparação para diversas atividades que, como a improvisação livre, dependem da interação eficiente do sujeito com o momento presente. Estes exercícios que o filósofo descreve preparavam o sujeito para a medicina, a retórica, o trabalho agrícola, as lutas, a música, etc.

Ainda que de formas talvez menos sofisticadas, são milenares as práticas de cuidar dos ferimentos, convencer pela linguagem verbal, cultivar a própria comida, defender-se ou atacar, fazer alguma forma de música. Todas estas atividades, em maior e menor grau, para que sejam realizadas, dependem da interação do sujeito que a realiza com o momento presente e suas imprevisibilidades. É no devir que morre o paciente, perde-se o argumento, murcha a planta, leva-se ou dá-se o soco, faz-se silêncio ou som.

Capacidades que permitem acolher o instante sem hesitar, para os filósofos que Michel Foucault estuda nesta obra, podem ser determinantes no desenrolar destas atividades. Mas que capacidades são estas exatamente? Como elas podem ser desenvolvidas? E como se relacionam com a improvisação livre? No início da primeira seção falarei sobre o cuidado de si helenístico-romano descrito por Foucault em sua genealogia deste conceito, e buscarei explicar brevemente algumas ideias apresentadas por Foucault para refletir a partir da relação destas com questões apontadas como determinantes em processos de preparação para improvisação livre nas entrevistas, experimentos e na literatura sobre esta forma de fazer música.

Não pretendo apresentar uma taxonomia da hermenêutica de Foucault que, mutatis mutandi, possa dar conta da improvisação livre. O trabalho do filósofo francês, colocado junto à improvisação, acredito, apresenta claras ressonâncias das quais tentarei falar, e outras questões que talvez digam respeito ao contexto singular no qual se insere sua produção. Não é necessário que todas as ideias que compunham o contexto histórico e filosófico estudado por Foucault possuam equivalência na livre improvisação. Isto seria um exercício pouco útil que revelaria mais da lente do que do objeto, uma vez que este estaria constantemente tentando adaptar os processos de preparação para a 
improvisação livre a uma espécie de gabarito. Pretendo aqui não separar pesquisador, lente, objeto e sim tentar olhar para o corpo relacional que se configura no meio do caminho entre os três e tantas outras linhas de força.

Do budismo aos feminismos, do cristianismo ao yuppie e suas atualizações, podemos ver que a existência de conjuntos de práticas que compõem e fundamentam processos de subjetivação, isto é, processos de transformação de si sobre si mesmo, não é restrita ao período descrito pelo filósofo francês ou a éticas específicas. Foucault opta por descrever pensamentos sobre diversos aspectos destes processos, na maneira como os gregos e romanos os entendiam. Esta escolha justifica-se pela rica e detalhada documentação de processos, conceitos e reflexões que, como mostra o autor, exercem influência determinante nas maneiras como vemos o mundo e a vida ainda hoje. Em um esforço para aumentar o leque desta reflexão, também olharemos para relações do pensamento de Foucault com outros autores que tratam de práticas de ascese e subjetivação. Cassiano Sydow Quilici, referência que emprestamos do teatro e da performance art, traz o conceito de cultivo de si, como descrito pelo filósofo japonês Yasuo Yuasa. Recorreremos ao trabalho de Quilici em diversos pontos desta dissertação para nos ajudar a compreender os processos de preparação em IL.

Entre os apontamentos de Foucault que parecem de grande relevância para a música que estudamos, há um processo sobre o qual falarei brevemente agora e aprofundarei na primeira seção deste trabalho. Refiro-me a certos caminhos determinantes que foram tomados na história do pensamento, como a separação do imperativo conheça-te a ti mesmo, de seu fundamento original, isto é, o cuidado de si. Esta cisão teve profundas consequências nas maneiras como olhamos para nós mesmos.

Aí se encontram fatores determinantes na escolha do filósofo francês por estes processos de subjetivação. Compreender a ruptura entre estes dois conceitos ajuda a compor partes importantes do quebra-cabeça no qual se encaixam as questões desta pesquisa de mestrado e oferece nova luz sobre discursos da improvisação livre dos quais falaremos adiante.

O cuidado de si descrito por Foucault possuía, além da busca pela virtude, um caráter inalienavelmente social. O cidadão deveria cuidar de si, mostra Foucault em Sócrates, não para si somente, mas para a polis. Havia uma inextrincável componente ética no cuidado de si. Um cuidado do outro. A separação observada por 
Foucault age deixando de lado justamente o que, segundo os gregos, levaria a este conhecimento de si: o cuidado. Ao comentar a relação entre o cuidado de si e cuidado do outro, Foucault diz:

\begin{abstract}
Chamemos esse movimento, também muito convencionalmente, em qualquer que seja o sentido, de movimento do éros (amor). Além dessa, outra grande forma pela qual o sujeito pode e deve transformar-se para ter acesso à verdade é um trabalho. Trabalho de si para consigo, elaboração de si para consigo, transformação progressiva de si para consigo em que se é o próprio responsável por um longo labor que é o da ascese (áskesis). Éros e áskesis são, creio, as duas grandes formas com que, na espiritualidade ocidental, concebemos as modalidades segundo as quais o sujeito deve ser transformado para, finalmente, tornar-se em sujeito capaz de verdade. (FOUCAULT. 2014:16.)
\end{abstract}

Feita a cisão, o sujeito dono de si e conhecedor de suas potências fica, então, isento de melhorar-se como um sujeito em coletivo. Basta possuir bons predicados, e saber vendê-los. O sujeito, segundo este pensamento, fica livre da ascese e do amor. Foucault mostra que nem sempre foi assim e aponta certas conveniências desta cisão. $O$ filósofo brasileiro Oswaldo Giacóia Junior ao falar sobre a relação entre estes conceitos que foram separados, isto é, o cuidado de si e o conheça-te a ti mesmo, afirma claramente a função dos exercícios de subjetivação:

\begin{abstract}
O sujeito em sua condição natural, tal como dado a si mesmo, não é capaz de verdade. Para tanto ele depende de um conjunto de operações de transformações, de modificações que o habilitam. Esta é a função dos exercícios. Não se pode ter acesso à verdade sem a modificação da forma de ser. É justamente por causa disso que as práticas espirituais diferem das práticas científicas para as quais basta apenas o direcionamento correto do olhar, a reforma do entendimento, a clareza e a distinção da evidência sem que nesse processo o sujeito tenha que se modificar posto que não é ele que deve ser transformado. ${ }^{13}$
\end{abstract}

Práticas espirituais, neste contexto filosófico, referem-se ao preço que se escolhe pagar pela aquisição da virtude. As maneiras pelas quais o sujeito deverá buscar a transformação de si. Como então transformar-se, colocar-se no devir de cada ato e agir como se deve? Além do trabalho intenso, Foucault indica que esta demanda não poderia ser atendida sem a consideração pelo outro e pela coletividade. Era para este fim que se adotava os exercícios e práticas que levariam ao conhecimento de si. Ainda que as compreensões helenísticas e estoicas do coletivo fossem excludentes e coercitivas para a maior parte dos cidadãos e cidadãs. Não há intenção em Foucault, tampouco no presente trabalho, em idealizar a forma como estes filósofos viviam.

\footnotetext{
${ }^{13}$ GIACÓIA in: X Colóquio Internacional Michel Foucault: “É inútil revoltar-se?” Foucault e as insurreições. http://cameraweb.ccuec.unicamp.br/watch video.php?v=H2ROXO1N6RB7. (Minutagem: 89:50) Link acessado em 30/05/17
} 
O que pretendo, por ora, é apontar algumas recorrências entre os pensamentos descritos por Foucault e outros filósofos, e ideias encontradas em discursos sobre a improvisação musical livre. Talvez seja importante dizer que estes discursos não carregam o fardo ou bandeira de voz oficial desta maneira de fazer música. Práticas congenitamente não normativas como esta resistem com ânimo a discursos monológicos. Há, todavia, uma série de musicistas, autoras e autores que se interessam pela relação entre a prática da improvisação musical e outras formas de intersubjetividade como a vida em coletivo. É neste contexto que se insere a presente investigação. A relevância da escuta e das formas de interação é recorrente nos discursos dos improvisadores aqui estudados, porém o transbordar destes valores e atitudes entre os universos da vida em coletivo e da improvisação livre nem sempre é visto da mesma maneira.

Os relatos específicos das entrevistas e experimentos são mais detalhadamente apresentados e discutidos na segunda seção. Nesta parte do texto relatarei também um experimento realizado com a Orquestra Errante, no qual propus dois exercícios específicos de improvisação baseados no trabalho de Chefa Alonso e Pauline Oliveros. Os exercícios buscam trabalhar questões de escuta, silêncio, decisão e interação. Após as realizações, os integrantes responderam algumas perguntas sobre a experiência. Refletirei nesta seção do texto sobre esta experiência e os relatos dos e das integrantes da orquestra. Também falarei nesta parte sobre minha experiência como instrumentista dentro deste grupo.

A partir dos diferentes referenciais teóricos escolhidos e acolhidos no decorrer da pesquisa, do material das entrevistas e do experimento com a orquestra, tentei elaborar algumas reflexões sobre cuidados de si na improvisação livre. Um dado relevante para esta investigação é que as quatro pessoas que compartilharam suas experiências possuem décadas de estudo e treinamento formal de música. Contudo, o ambiente da improvisação livre é ocupado por pessoas dos ofícios mais variados. A não obrigatoriedade do domínio das técnicas e idiomas musicais tradicionais cria um ambiente, no qual pessoas com pouca ou nenhuma experiência musical formal, podem contribuir com musicistas profissionais, em relação de igualdade, para a música ali criada. Este trabalho pretende servir não só para musicistas e pesquisadores de música, mas para qualquer um ou uma que se interesse pelos diversos assuntos que parecem conviver com esta manifestação musical. 
SEÇÃO I

IMPROVISAÇÃO LIVRE E CUIDADO DE SI 
Assim como a improvisação livre, o cuidado de si pode ser compreendido, como dissemos, de diversas formas que podem ser aplicadas com intuitos às vezes bastante distintos dos apontados por Michel Foucault em sua Hermenêutica do Sujeito. O cuidado de si, do qual fala Foucault nessa obra, envolve o trabalho de um sujeito que busca constantemente transformar a si mesmo, e organiza práticas e técnicas para uma finalidade que também é ética. $\mathrm{O}$ autor se interessa por uma filosofia anterior à cisão entre o cuidado e o conhecimento de si. A yoga do empresário que pretende ser mais lucrativo ou a renúncia de si em favor de uma vida posterior, como na ascese cristã descrita por Foucault, embora possam ser vistas como cuidados de si, estão distantes das formas clássicas descritas pelo filósofo em sua hermenêutica e também não interessam para esta pesquisa. Insisto em exemplos tão díspares para enfatizar que as relações observadas entre a IL, e os processos de cuidado de si pelos quais esta pesquisa se interessa, acontecem principalmente no campo da ética e da relação com o outro.

Para compreender melhor como se cruzam e se entrelaçam estes universos, olharemos a seguir, para algumas ideias e práticas apresentadas pelo filósofo 
francês e relacionaremos este pensamento a práticas e discursos da improvisação livre. Estes discursos, de forma alguma, pretendem representar verdades gerais, e sim recortes desta prática não normativa a partir de escolhas do pesquisador por bibliografias e artistas que tratam de alguma forma das questões que interessam à pesquisa. Há certamente inúmeras maneiras de compreender qualquer tendência musical. $\mathrm{O}$ que este trabalho intenta, visto de forma deleuziana, é olhar para adensamentos de linhas convergentes que formam esta faceta da improvisação livre que relaciono ao cuidado de si, descrito por Foucault na obra mencionada no parágrafo anterior. A multiplicidade da qual a improvisação livre faz parte e as linhas de fuga que também a compõem certamente não serão nem de longe esgotadas no presente texto.

Michel Foucault não aborda diretamente questões de música embora comente que esta era uma das atividades às quais serviam os processos clássicos de ascese que descreve. A questão tratada por Foucault em seu curso de 1982 é das mais antigas e difíceis, e certamente extrapola a improvisação musical ou de qualquer tipo: como, através de práticas e técnicas de si, dá-se a construção do próprio sujeito? Foucault busca compreender como são pensadas, escolhidas e organizadas as práticas de quem busca, por meio destas, chegar à virtude. Mas como se pretende chegar lá? O que é necessário transformar em si para se ter acesso ao que se pretende acessar? E no âmbito desta pesquisa, estas questões podem ser relevantes para musicistas de improvisação livre? Adianto que nenhuma destas perguntas possui resposta única. Entre as entrevistas individuais, o trabalho com a Orquestra Errante, e a revisão bibliográfica, houve apenas indícios de caminhos constantemente cortados por linhas que ora os contrariam, ora os apoiam. Procurar, portanto, por qualquer resposta generalizável não é do interesse desta pesquisa.

Pretendo refletir sobre como algumas destas ideias apresentadas por Foucault ressoam nestes processos musicais. Alguns conceitos e práticas apresentadas pelo autor servem de disparador para reflexões acerca de determinados aspectos da improvisação. Servem como referência de reflexões em outros campos de conhecimento. Este processo de busca fora da literatura propriamente musical nos permite observar aspectos da nossa prática que possivelmente tenham passado desapercebidos.

Pessoas interessadas em abordar questões como escuta e interação não hierárquica talvez possam valer-se destas reflexões para criar processos de preparação 
que se adequem às suas necessidades. Espero que este material possa servir a musicistas e grupos que intentam desenvolver uma interação criativa e coerente com os discursos que acompanham boa parte da prática da improvisação. 


\section{Exercícios}

Uma das primeiras semelhanças entre os universos que compõe esta pesquisa encontra-se na não uniformidade dos exercícios da ascese clássica. Práticas diversas, mostra o Foucault, formavam o que era entendido como parte de um amplo processo de preparação de todo o sujeito. Estes processos variavam consideravelmente de um sujeito para o outro e cada processo transformava-se de acordo com as necessidades diagnosticadas pelo próprio sujeito. Pretendo mostrar nesta seção que esta variedade e variabilidade também estão presentes em certos círculos de improvisação livre e outros aspectos deste pensamento filosófico também possuem ressonâncias dentro da improvisação.

Estes exercícios ajudam a compor o elaborado preço a se pagar pela virtude $^{14}$ que envolve até mesmo aspectos éticos e não raro toda vida do sujeito como este a compreende. Ou seja, o que é preciso fazer para transformar em si mesmo o que se

\footnotetext{
${ }^{14}$ Foucault fala de um cuidado de si que compreende a virtude como a competente realização das atividades para as quais se prepara, e o cuidado com o outro. Para uma reflexão em relação a quais são estas virtudes a serem desenvolvidas por musicistas de IL, ver na terceira seção desta dissertação as ideias de Cornelius Cardew e Chefa Alonso.
} 
acredita necessário? De certa forma, aplicada a processos de improvisação livre, esta é a questão fundamental de onde parte a presente pesquisa. Este preço diz respeito ao que Foucault e outros autores chamam de "exercícios espirituais". A palavra espiritualidade aqui não possui aqui qualquer sentido religioso. $\mathrm{O}$ autor indica que:

(...) poderíamos chamar de "espiritualidade" o conjunto de buscas, práticas e experiências tais como as purificações, as asceses, as renúncias, as conversões do olhar, as modificações de existência, etc., que constituem, não para o conhecimento, mas para o sujeito, para o ser mesmo do sujeito, o preço a pagar para ter acesso à verdade (FOUCAULT, 2014:15).

Existem diferentes pontos de intersecção entre estes exercícios e práticas da improvisação livre. Em relação à maneira como são administrados, vemos em Foucault, que deveriam ser organizados livremente por quem os praticava em função de como o praticante os percebia necessários. Há inevitavelmente um caráter de subjetividade, de escolha, que nos remete a processos de improvisação livre. Os dois exemplos a seguir pretendem reforçar esta relação.

Em um artigo de 2013 Villavicencio, Iazzetta e Costa $^{15}$ descrevem a maneira com que cada musicista de improvisação livre deve buscar a expansão das possibilidades sonoras de seu instrumento por meio de técnicas estendidas e desenvolverse nas novas possibilidades descobertas. Este processo inevitavelmente inclui particularidades de cada instrumento e instrumentista que geram dificuldades específicas que requerem tratamento singular. Embora tenhamos hoje boas trilhas para nos guiarmos nestas buscas pela expansão sonora de nossos instrumentos, cada musicista deve buscar organizar suas práticas de acordo com o que considera importante ou interessante. Este processo também parece condizente com o discurso de Felix Guattari e Suely Rolnik:

Para que se efetivem os processos de reapropriação da subjetividade - tais como os de um grupo de psiquiatrizados; de um grupo de pessoas que querem organizar sua vida de um outro modo; de uma minoria social que quer se desfazer dos sistemas de coação que tendem a modelizá-la; de um grupo de mulheres que, mesmo em pequena escala, querem se libertar do sistema opressivo de que são objeto há milênios; de um grupo de criadores que querem se livrar dos sistemas padronizadores em seu campo, ou até de crianças que se recusam a aceitar o sistema de educação e de vida que lhes é proposto - para que estes processos se efetivem, eles devem criar seus próprios modos de referência, suas próprias cartografias, devem inventar sua práxis de modo a fazer brechas no sistema de subjetividade dominante. (GUATTARI e ROLNIK, 1996:49/50)

Ainda que no âmbito estritamente técnico, é preciso considerar a frequente presença de instrumentos não tradicionais, criados pelos próprios

\footnotetext{
15 VILLAVICENCIO, IAZZETTA E COSTA, 2013A.
} 
instrumentistas e que demandam seus próprios processos de descoberta. Não parece possível, portanto, um manual que dê conta de todas as possibilidades sonoras de um instrumento, muito menos um guia genérico de preparação para improvisação. A elaboração e administração, por parte de cada musicista, dos exercícios dos quais esta ou este se valerá, também é ressaltada pela guitarrista e musicista de improvisação livre Mary Halvorson ${ }^{16}$. A improvisadora fala sobre a importância de cada instrumentista criar seus próprios exercícios musicais a partir das particularidades de seu instrumento.

A multiplicidade das práticas relacionadas à preparação relatadas nesta pesquisa, bem como a maneira com que estas são organizadas, parece ser fruto de processos mais flexíveis e impermanentes, organizações mais fluidas que, como no caso da ascese clássica descrita por Foucault, exigem que sejam feitas escolhas e se crie caminhos sempre singulares. Uma grande variedade destes exercícios espirituais da antiguidade é documentada por Fílon de Alexandria, filósofo do judaísmo helênico que viveu entre 10 a.C. e 50 d.C., período posterior ao observado por Foucault. Esta documentação é estudada por Pierre Hadot, filósofo francês contemporâneo de Foucault com o qual este apresentava diversas convergências. O trabalho de Hadot também apresenta claras ressonâncias com discursos da improvisação livre, como tentarei mostrar a seguir.

Em seu livro Exercícios Espirituais e Filosofia Antiga, Hadot mostra como Fílon organiza estes exercícios em três grupos distintos em relação ao caráter e objetivo de cada exercício. O primeiro destes grupos inclui exercícios relacionados à atenção, às meditações, às lembranças do que é o bem. $\mathrm{O}$ segundo é composto por exercícios mais intelectuais como a leitura, a escuta, a investigação e o exame aprofundado. O último, formado por exercícios mais ativos envolve o domínio de si, o cumprimento dos deveres e a indiferença às coisas às quais se deve ser indiferente.

Estes objetivos e práticas apontados por Hadot parecem estar presentes em importantes referências na literatura sobre improvisação. Somente no âmbito desta pesquisa podemos encontrar várias recorrências. No artigo mencionado no parágrafo anterior, por exemplo, os autores destacam a importância fundamental da escuta e da

\footnotetext{
${ }^{16}$ HALVORSON em vídeo feito para uma biblioteca virtual de aulas de jazz. Link acessado em 30/05/17: https://www.youtube.com/watch?v=pMRytFD2eGA\&t=6s
} 
atenção ao outro. Também ressaltam a questão ética como um dos fundamentos desta prática musical.

Igualmente interessada em processos de escuta, Pauline Oliveros foi criadora do termo Deep Listening que se refere a uma série de práticas que desenvolveu em sua longa carreira. O trabalho de Oliveros possui relação com práticas de subjetivação orientais como o budismo e tem como parte importante as meditações musicais. Em mais uma intersecção com os exercícios espirituais da antiguidade, a musicista faz referência, na entrevista em anexo, ao domínio de si advindo de sua prática de artes marciais.

Em relação às lembranças do que é o bem, Chefa Alonso afirma que os preceitos básicos da improvisação livre são a democracia e o respeito pelo outro. Susan Alcorn também destaca a importância do respeito, da atenção e da escuta nos processos de improvisação coletiva.

Ainda acerca dos exercícios espirituais, Foucault nos apresenta o trabalho de Musonius Rufus, filósofo estoico, que discorre sobre a ascese filosófica e também fala em exercícios de três tipos: corpo, alma, e de corpo e alma, concentrando-se nos dois últimos. Embora não ofereça detalhes específicos a respeito das práticas, Foucault aponta que para Rufus, realizavam a função de reforçar dois atributos que são igualmente determinantes em qualquer improvisação: a coragem (Andreia) e o domínio de si (Sophrozyne). 


\section{Coragem e domínio de si}

Em relação ao primeiro destes atributos algumas situações musicais parecem relevantes. Além do desejo inicial de participar, um tanto de coragem é indispensável para improvisar. Em práticas musicais improvisatórias podemos também destacar a importância de ser capaz de colocar-se em proeminência sem esconder-se nas massas sonoras criadas pelo grupo, bem como de ser capaz de sugerir novos caminhos para ou, ainda, descobrir sons em tempo real. Em termos mais gerais, a coragem talvez seja também determinante na maneira como se encara o desenrolar dos exercícios de improvisação propostos em grupos como a Orquestra Errante. O medo de errar perde o sentido. Temos, na improvisação livre, a possibilidade de saltar como quisermos para o vazio. O erro passa a ser, como entende Cage, "simplesmente uma falha em ajustar-se imediatamente de uma preconcepção para uma atualidade" (CAGE, 1976:170) ${ }^{17}$, e ainda assim são apenas parte inevitável do processo.

${ }^{17}$ Tradução minha. 
As práticas que levarão à desejada virtude serão inevitavelmente também experimentais e passíveis de mudança. Ao falar sobre exercícios da antiguidade, Salma Muchail cita, no X Colóquio Internacional Michel Foucault, realizado na Universidade de Campinas (UNICAMP), o filósofo Arnold Davidson. Davidson, segundo Muchail, fala em exercícios de "pensamento, imaginação, sensibilidade, vontade, metamorfose de si mesmo... risco." ${ }^{18}$. O autor afirma sobre estes exercícios: "eles saem dos trilhos."

No sentido de transformar em ato aquilo que se acredita, o segundo atributo, isto é, o domínio de si, também parece oferecer ressonâncias em diversas etapas do processo improvisatório, da preparação à performance. $\mathrm{O}$ frequente desandar de certos exercícios e dinâmicas de improvisação em improvisações livres parece um bom exemplo de como um maior domínio de si poderia contribuir para estes processos. Com função de aprimorar ou levar à atenção esta ou aquela questão, propostas são apresentadas ao grupo. A tentação de improvisar livremente, não raro, leva musicistas a ignorarem as regras do jogo por completo. A proposta é abandonada em pleno voo dando lugar a algo mais livre e menos focado nos objetivos do exercício em questão. Por outro lado, seguir as regras cegamente, ou melhor, surdamente, pode resultar em um exercício burocrático e sem vida alargando em pouco ou nada as possibilidades expressivas das pessoas envolvidas.

Outra faceta do domínio de si na improvisação livre é a maneira como cada musicista reflete sobre e administra seus próprios automatismos. Não basta conhecer a si mesmo. São necessárias formas de atuar sobre si para que não nos entreguemos a caminhos tão viciados. Para que não toquemos sempre as mesmas coisas, estabelecendo sempre os mesmos tipos de relação. Um maior domínio de si pode estar relacionado à escuta, à capacidade de concentração e silêncio, à tentação de tocar o que se sabe, de recorrer à palheta de sempre, de querer parecer bom no que faz. Abrir mão de certos expedientes criados com muito esforço envolve uma boa dose de coragem. A ideia de domínio de si também pode estar ligada à maneira como musicistas de improvisação livre tratam a relação com os idiomas musicais que compõe seus repertórios de referências e habilidades. Falarei mais sobre esta questão adiante.

\footnotetext{
${ }^{18}$ HADOT In SALMA. Fala no X Colóquio Internacional Michel Foucault: "É inútil revoltar-se?" Foucault e as insurreições. http://cameraweb.ccuec.unicamp.br/watch_video.php?v=UR7S6K15UR27 Link acessado em 30/05/17. (Minutagem: 26:00)
} 


\section{Finalidades}

A não existência de um grupo consensual de exercícios, como entre as diferentes asceses filosóficas, parece presente em diversos processos de preparação em improvisação livre. Não se trata, no entanto, de ligar artificialmente coisas que não possuem relação. A filósofa e tradutora de Foucault, Salma Muchail, no mencionado colóquio sobre Foucault, de onde tiramos nossas referências à obra de Pierre Hadot, aponta que para este, há uma unidade em meio à enorme diversidade de práticas, nos meios empregados e na finalidade buscada. Não pretendo, no entanto, afirmar que esta unidade se estende pela improvisação livre e sim observar lugares da livre improvisação onde podemos notar estes fatores descritos por Hadot.

Em referência à acesse clássica, Hadot destaca que há sempre uma conversão e uma crença na liberdade da vontade. Estes dois fatores parecem atravessar todos os discursos sobre improvisação aqui coletados. O próprio nome improvisação livre já indica algumas semelhanças. A questão da conversão, ou seja, das transformações de si, é o que esta pesquisa pretende investigar. 
Entre as finalidades apontadas em Foucault e nos relatos de musicistas, destaca-se a questão ética deste sujeito que se prepara para a vida em coletivo enquanto, de fato, a vive. Este cuidado de si que é dinâmico, sempre em processo, aberto e estabelecendo novas relações singulares, não pode existir sem o cuidado do outro. Michel Foucault foi acolhido nesta pesquisa pelos frequentes cruzamentos entre as ideias que apresenta e a maneira como certos autores e improvisadores vêm a prática da improvisação. A questão ética é sem dúvida uma das maiores recorrências e atravessa desde os processos de preparação e reflexão, como mencionamos, até o objetivo final da atividade que se exerce, formando um emaranhado inseparável que pode ser olhado por diversos ângulos.

Esta questão está diretamente ligada a uma das questões levantadas nas entrevistas. A partir da pergunta “o que é uma boa improvisação para você?", pretendíamos olhar para os ideais buscados em preparações para uma improvisação livre. A importância da relação com o outro fica bastante evidente em todas as respostas que em geral gravitavam em torno da ideia de que uma boa improvisação é uma na qual todos se escutam com atenção e respeito, e agem quando devem agir. A extrema simplicidade desta pergunta pode parecer excessivamente vaga ou banal. Um olhar mais atento revelaria que dificilmente todos saem de uma improvisação com a mesma sensação de que foi boa ou ruim. Não se trata de verificar os resultados e sim de compreender as relações. 


\section{Banalidade}

Além da questão ética, outro aspecto parece comum a estes processos de subjetivação. Muchail, destaca o aparente caráter de banalidade frequentemente associado a estas múltiplas práticas. Esta observação talvez ajude a compreender os motivos pelos quais pessoas externas a este tipo de processo podem não entender a importância de determinadas práticas.

Rogério Costa contou durante a entrevista que acredita que o hábito de andar de bicicleta o ajuda, de alguma forma a improvisar. Mas como este hábito poderia contribuir para um improvisador? Além de negociar fluxos coletivos de movimento com o corpo e os sinais que este emite, o ciclista deve dedicar todos os seus sentidos às contingências mais variadas e agir criativa e eticamente no instante em que as percebe. Fora a contundência um tanto mais obvia de uma fratura exposta em relação a um som indesejado, acredito que existam semelhanças razoáveis. No entanto, nossa formação musical nem sempre atua sobre habilidades como estas.

Não se nega, na educação musical tradicional, a importância do desenvolvimento da interação, concentração e escuta. Apenas espera-se que, por meio de 
exercícios técnicos e musicais, além de aulas de teoria, instrumentistas, com o tempo, desenvolvam estes atributos por conta própria em suas práticas musicais. Ainda que sejam determinantes para a execução musical, são frequentemente considerados secundários e seu desenvolvimento é descartado em alguns processos de formação musical.

Dada a relevância acentuada destas habilidades na livre improvisação parece normal que práticas que visam o seu desenvolvimento se tornem parte dos processos de preparação para improvisar. Este caráter não é exclusivo destes processos de subjetivação em especial. É comum a prática de buscar em atividades variadas o auxílio para desenvolver-se em um ofício e para a vida.

Em um exemplo bastante conhecido, muitos se lembrarão do famoso dilema de Daniel San - personagem do filme Karatê Kid - que, contrariado, acata as ordens de seu mestre e pinta a cerca mesmo sem ver relação direta com a sua capacidade de defender-se em uma luta física. Distante desta jocosa ficção hollywoodiana - que embora divertida, apresenta uma versão um tanto reducionista do cuidado nas artes marciais - o zen ${ }^{19}$ budismo tem em sua prática atos simples como caminhar lentamente, ficar sentado, e respirar. Quilici em artigo sobre o conceito de cultivo de si das artes tradicionais japonesas afirma:

Os aspectos múltiplos desse treinamento podem ser sintetizados em três: ética, práticas contemplativas, conhecimento experiencial. O desenvolvimento ético aparece como um elemento fundamental, já que se trata de levar ao cotidiano uma atitude atenta, que aos poucos ajuda a desconstruir hábitos automáticos e grosseiros. $\mathrm{O}$ grosseiro identifica-se aqui com tendências arraigadas de negação e reatividade à impermanência, que se manifestam em múltiplas formas de apego e aversão. A ética não se reduz assim a um código moral que deve ser mecanicamente obedecido, mas a um exercício de atenção no cotidiano, que envolve uma percepção mais refinada da fala, da ação, da intenção envolvida nas atividades. Como se algo da atenção que exigimos de um ator num palco ou numa situação laboratorial fosse levada para o dia a dia, tendo em vista a lapidação da percepção e o desinvestimento das energias em hábitos automáticos. Para tanto, às vezes são necessários gestos de contenção, nãoações, que interrompem os circuitos compulsivos dos hábitos. Nesse sentido, a ética pode ser relacionada a uma arte da existência cotidiana, que faz do enfrentamento das situações diárias, um trabalho básico do praticante. (QUILICI, 2011:3)

Sobre este caráter cotidiano também encontrado nos exercícios da ascese clássica, Muchail cita Hadot no colóquio mencionado há pouco:

Cotidianos, os exercícios não se ordenam no plano abstrato ou estritamente teórico. Incluem conhecimento, mas menos o conteúdo cognitivo, mais o caminho ao

${ }^{19}$ SUZUKI, 1970. 
conhecimento. São marcados pela simplicidade. Às vezes são até triviais. Podem ter aparência de banalidade. São experiências. ${ }^{20}$

Yoga, meditação, artes marciais, ciclismo, cantar no carro, eutonia, jardinagem e outras práticas, que sob um olhar menos atento poderiam ser vistas como banais e irrelevantes foram colocadas como determinantes nos relatos aqui colhidos. Como nos exercícios da ascese filosófica, vimos que há uma diversidade considerável na maneira como diferentes musicistas compreendem esta ou aquela prática como influente no processo improvisatório. Ao passo que a disciplina das artes marciais pode ser considerada benéfica por alguns improvisadores, outros podem encontrar o que procuram em situações bem menos formais como experimentando sons vocais enquanto dirigem. O que há em comum é que ambos buscam uma transformação, seja pela inclusão de novas possibilidades sonoras e na coragem para usá-las, seja no domínio de si advindo da disciplina. Ambos parecem partir de um desejo de criar com liberdade. Estas práticas, segundo Muchail, "mais formam do que informam"21.

\footnotetext{
${ }^{20}$ Fala no X Colóquio Internacional Michel Foucault: "É inútil revoltar-se?” Foucault e as insurreições. http://cameraweb.ccuec.unicamp.br/watch_video.php?v=UR7S6K15UR27 Link acessado em 30/05/17. (Minutagem: 26:00)

${ }^{21}$ Ibidem. (Minutagem: 24:00)
} 


\section{O desenvolvimento das ferramentas}

O termo grego, epiméleia heautô̂, central no estudo de Foucault, busca cingir este vasto conjunto de práticas e exercícios e traz as ideias de "cuidado de si mesmo, ocupar-se de si mesmo, preocupar-se consigo". (Foucault, 2014:4) Por meio desta organização, o sujeito deve tornar-se forte para superar as contingências e seguir seu caminho. Estas organizações na maneira como foram ampla e cuidadosamente pensadas e documentadas por filósofos clássicos, alimentaram o interesse de Foucault por este período.

A simulação da atividade para qual o sujeito se prepara e as diferentes práticas de pensamento sobre o ato a ser realizado, certamente podem ocupar lugar de destaque na maneira como musicistas de improvisação realizam seu trabalho e compreendem seus processos de preparação. Para descrever esta preparação aberta do corpo que simula a atividade e sua realização, os filósofos gregos usavam o termo Gymnázein. Logo voltaremos a este termo. Antes, porém, gostaria de falar um pouco sobre uma questão central no desenvolvimento de muitos musicistas que acredito ter um peso considerável na maneira que são feitas estas simulações. 
Para compreender como funcionariam estas simulações, e seus paralelos na improvisação livre, gostaria de olhar para a maneira como frequentemente acontece o desenvolvimento destas e destes musicistas, e de que ferramentas se valem neste processo. A capacidade de improvisar é, amiúde, desenvolvida dentro de territórios idiomáticos como o choro, o jazz, o rock, o flamenco, etc. As ferramentas são aquelas que, exaustivamente testadas e infalíveis, produzem sons que imediatamente evocam uma realidade musical localizada. Mas seria possível desenvolver a capacidade de improvisar música, sem que seja por meio de uma técnica ou idioma em particular?

A improvisação livre reiteradamente apresenta discursos que defendem que a criação não esteja submetida às regras de nenhum idioma musical específico. Esta postura tem consequências consideráveis. Ao afrouxarmos as leis dos idiomas deparamo-nos com certa falta de chão. Como se decidíssemos jogar futebol, porém sem times, bola ou gol. O treinamento de antes não servirá. Outros jogos terão de ser criados e outras práticas os prepararão. Costa vê na improvisação livre a ideia de um jogo cujas regras são criadas ao jogar. Assim a preparação também não pode ser uma atualização de regras anteriores ao momento da prática, reiteradas ad nauseam.

Os processos de preparação que estudamos são dinâmicos. Alguém que entra em campo em um jogo como este, firmemente apegado às regras e tradição deste ou daquele jogo, talvez encontre dificuldades para integrar-se. No tipo de relação que nos interessa, o sujeito transforma-se, mas também é transformado. O processo de subjetivação envolvido só é pleno na negociação imanente que surge do coletivo. Criar este terreno intermediário que substitui o idioma e que existe entre a preparação cotidiana para improvisação e a improvisação como preparação para o cotidiano, coloca em cheque o dualismo entre ato e preparação e vai muito além dos idiomas.

Derek Bailey, em seu conhecido livro sobre a natureza da improvisação, advoga por uma prática livre das obrigações dos idiomas musicais. Esta mesma questão recebe tratamento bastante próximo no discurso de todas as pessoas entrevistadas neste trabalho. Todas defendem, de diferentes formas, a necessidade de libertar-se das amarras dos idiomas musicais. Portanto cabe definir melhor do que estamos falando. Em sua tese de doutorado, Rogério Costa propõe uma ampliação deste termo que pode ser bastante útil para a presente reflexão: 
$\mathrm{O}$ termo idioma que temos utilizado com frequência no presente trabalho recebe aqui uma definição complementar: se refere aos territórios da prática musical que se constituem por um lado de partes abstratas onde se encontra o que se repete: gramáticas (regras de articulação das unidades significativas, etc.) e vocabulários (materiais); e de outro de partes concretas ligadas à prática, onde se insere a diferença. É, por exemplo, o idioma do período barroco que compreende formas de organização (gramáticas melódicas, harmônicas, etc.) um repertório de materiais (acordes, timbres, etc.) e os "jeitos" concretos de fazer musical que não estão na partitura. (COSTA, 2003:100, nota: 60)

A frequente passagem por idiomas musicais ajuda a definir as condições a partir das quais um grande número de musicistas de IL criam, compreendem e fazem uso de suas práticas de preparação. O desenvolvimento da técnica instrumental na maior parte das vezes coincide com o aprendizado de elementos destes idiomas. Nestes processos, os dedos aprendem a acertar o alvo com destreza, mas são sempre mais ou menos os mesmos alvos já codificados e massivamente reproduzidos, e frequentemente pouco afeitos a modificações profundas. Quando são inevitavelmente carregados para dentro da sala de ensaio de improvisação livre, podem se mostrar inflexíveis, pouco dispostos a se transformar com os outros em uma gramática impermanente e única. As relações perdem horizontalidade e o elemento idiomático se apresenta com suas regras implícitas alheias ao todo, polarizando a escuta.

Contudo, o que é proposto não é que o passado de cada musicista seja deixado do lado de fora da sala de trabalho, o que parece pouco plausível. Costa aponta que embora os idiomas musicais surjam com alguma frequência, para que façam parte do plano de consistência da improvisação livre, devem passar por um constate processo de territorialização e desterritorialização de maneira que, suficientemente transformados, integrem-se ao todo.

As ideias de plano de consistência, territorialização e desterritorialização, além de outros termos deleuzianos, são utilizadas pelo autor para falar sobre a improvisação livre, e podem ser melhor compreendidas em seu livro Música Errante $^{22}$ ou em sua tese de doutorado ${ }^{23}$. Em uma explicação breve poderíamos definir o plano de consistência como o ambiente da improvisação livre, onde, segundo Costa, "coexistem diferentes energias, atitudes singulares, pensamentos, conexões, histórias pessoais e coletivas" (COSTA, 2016:39). Por territorialização e seu oposto, entendemos

\footnotetext{
${ }^{22}$ COSTA, 2016.

${ }^{23}$ Idem, 2003.
} 
os idiomas, estilos e sistematizações, que em meio à alternância entre estes processos descritos por Deleuze ajudam a formar o plano de consistência da IL.

No artigo já mencionado com Villavicencio e Iazzetta, Costa afasta-se ainda mais dos idiomas musicais ao propor uma escuta baseada na ideia da escuta reduzida, de Pierre Schaeffer, pai da música concreta. Segundo este modo de escuta, o interesse volta-se para as particularidades do som e não para a ideia abstrata de nota e seus desdobramentos. A espectromorfologia de Denis Smalley também é uma das referências pedagógicas utilizadas por Rogério na Orquestra Errante.

Ao falar em sua tese de doutorado sobre as maneiras "como o tempo se delineia" 24 em uma improvisação livre, Costa ressalta as relações subjetivamente estabelecidas com os passados. O autor descreve diferentes tipos de sínteses de memória e a maneira como estas podem estar relacionadas ao papel do passado e da biografia de cada instrumentista no ambiente da improvisação livre. Costa ressalta que em um ambiente que pretende não ser idiomático, estes elementos da memória de longo prazo dos instrumentistas precisam ser "ressignificados por algum procedimento de desterritorialização/reterritorialização, "colagem, raspagem, distorção, fragmentação, etc." (COSTA, 2003:101)

A polifonia, palavra emprestada da música pelo filósofo russo Mikhail Bakhtin para descrever parte da obra de Dostoievski também possui, segundo esta acepção, implicações que remetem à improvisação livre. Bakhtin fala sobre uma literatura na qual o autor e os personagens possuem igual importância e potência. Este conceito pode nos ajudar a refletir sobre o ambiente buscado em certos contextos de improvisação livre. Em ampliação do conceito bakhtiniano, o linguista Carlos Alberto Faraco sugere que a polifonia trata-se de uma categoria ética na qual todas as vozes de uma situação dialógica estão em equipolência.

Em outra contribuição das ideias de Bakhtin, o pesquisador grego Panagiotis Kanellopoulus em artigo sobre a estética da improvisação livre e suas implicações educacionais, parte de um ponto de vista bakhtiniano para propor formas de compreender a improvisação livre que enfatizam a obrigação de explorar o desconhecido

\footnotetext{
${ }^{24}$ Ibidem.
} 
em uma "busca por liberdade por meio da responsabilidade de atos irrevogáveis, de atender à unicidade de atos irrevogáveis”. (KANELLOPOULUS, 2003: 101)

Voltando a Foucault, um cruzamento com a IL parece se dar no sentido que este ideal polifônico é atualizado por meio de heterotopias nas quais se busca estratégias para contornar esta tendência de tocar o que já se conhece. Bem como, na ascese filosófica, o sujeito precisa desconstruir certos vícios.

Além da questão idiomática outros vícios musicais passíveis de transformação se mostram presentes em ambientes de improvisação. Em mais um ponto de intersecção entre a base filosófica deste trabalho e o movimento musical do qual falamos, Muchail indica que "a tagarelice constitui, segundo Foucault, o primeiro vício do qual deve curar-se quando se começa a aprender a filosofia e nela se iniciar." ${ }^{25}$ Não é difícil imaginar um paralelo na improvisação livre, mas vale citar a improvisadora Chefa Alonso que ao descrever em seu relato o que acredita ser uma das maiores dificuldades da improvisação livre, acusa: "Difícil é calar-se. É admitir que em silêncio está muito bem como parte da música." 26 Embora seja recorrente na literatura musical, como mostramos, as referências à importância de certas capacidades como ficar em silêncio e estar atento ao outro, são menos frequentes os trabalhos de preparação musical que abarcam o desenvolvimento destas capacidades.

O compositor germânico brasileiro Hans Joachim Koellreutter é um destes raros casos. Koellreutter coloca a música em um espectro mais amplo e a compreende junto a ideias da filosofia, física moderna, zen budismo e outras referências. A pesquisadora em educação musical Maria Teresa Alencar de Brito, que trabalhou muitos anos com Koellreutter, oferece contribuições importantes para pensarmos sobre a maneira como questões extramusicais, ou que não envolvem diretamente a produção física de som, são inseparáveis dos processos criativos sonoros. Seu trabalho pedagógico é repleto de jogos de improvisação nos quais, frequentemente, questões extramusicais são abordadas através do som, e a criação de sons é precedida por reflexões e estímulos de cunho extramusical. Diversos jogos que exploram estas relações podem ser encontrados

\footnotetext{
${ }^{25}$ FOUCAULT In: MUCHAIL. Fala no X Colóquio Internacional Michel Foucault: "É inútil revoltarse?" Foucault e as insurreições. http://cameraweb.ccuec.unicamp.br/watch_video.php?v=UR7S6K15UR27 Link acessado em 30/05/17.
} ${ }^{26}$ ALONSO, 2016. Tradução minha. Revisão de Miguel Antar. 
no livro de Brito intitulado Koellreutter educador: o humano como objetivo da educação musical. ${ }^{27}$

Em relação ao que possivelmente se definiria como extramusical, podemos encontrar a ideia helenística de Melatân. Longe de ser banal, este exercício de apropriação de um pensamento era sem dúvida, segundo Foucault, parte fundamental da ascese helenística. Este termo que está na origem da palavra grega epimeleia é frequentemente ligado à palavra Gymnázein, e possui também o sentido de exercitar-se e treinar. A Melatân, em geral compreende formas cognitivas como práticas de pensamento. Sua tradução para o latim possui relação estreita com a palavra meditação, mas de forma alguma deve ser confundida com passividade. Melatân é um exercício do pensamento sobre si mesmo.

Isto posto, intrigava-me saber como os entrevistados desta pesquisa compreendem os processos mentais envolvidos na improvisação. Mais especificamente, como se dá a relação - para cada instrumentista que ofereceu seu relato - entre sua prática de improvisação livre, e os processos mentais que acreditam estarem relacionados a esta prática? Ou seja, como estas pessoas acreditam que aquilo que pensam, e como pensam, se relaciona com a música que fazem?

${ }^{27}$ BRITO, 2001. 


\section{A preparação para o desconhecido}

Os processos de ascese descritos por Foucault se inserem entre reflexões acerca da preparação para a ação sem roteiro definido. Tanto a vida em sociedade, que amiúde não acontece de maneira programada, quanto práticas de improvisação livre dependem sempre do momento presente e suas imprevisibilidades. Entendemos aqui por preparação, portanto, mais do que apenas o ensaio técnico motor do que será apresentado ao público. Embora este também seja de grande relevância para esta pesquisa, esta preparação motora é certamente bem mais documentada do que as outras habilidades envolvidas na IL. Chefa Alonso, em seus ateliês e produções escritas, fala em escuta, concentração, interação, confiança, decisão, energia, silêncio, memória, risco e intenção. ${ }^{28}$

A preparação para a execução de música composta em tempo diferido, ou seja, composta e escrita em um dado momento e tocada em outro, certamente exige igual afinco e poderia igualmente ser pensada em relação ao cuidado de si. Porém, há

\footnotetext{
${ }^{28}$ ALONSO, 2014. Tradução minha.
} 
uma distinção fundamental entre a execução de música escrita e a improvisação livre, que faz com que a segunda se mostre mais relevante para o presente estudo aos olhos do pesquisador. A partitura fornece alvos relativamente claros. A improvisação é sempre um salto no escuro. Como então preparar-se para o salto?

Esta pergunta é antiga e para os filósofos estudados por Foucault, aplica-se a diversas atividades. O trabalho agrícola, a retórica e a música, todas dependem em grande parte do momento e contexto em que acontecem e podem valer-se, como mostra Foucault, de uma preparação rica e variada que contemple esta necessidade de agir no presente. A obra do filósofo francês nos traz, como falei, exemplos de tentativas de transformações de si para fins específicos, compostas de técnicas e práticas que se organizam sob o conceito de cuidado de si.

A relação com o outro, bastante estimada no ambiente da livre improvisação, também é parte fundamental na Áskesis, como mostra Foucault que explica o cuidado de si como "uma atitude geral para consigo, para com os outros, para com o mundo"29. Para Sócrates, Foucault cita, "o cuidado de si é [...] um princípio de movimento, um princípio de permanente inquietude da existência... o momento primeiro do despertar." (FOUCAULT, 2014:9)

Embora este tipo de reflexão não seja corrente no estudo acadêmico da música, outras áreas o tem em grande importância. Na filosofia, além de Foucault, o filósofo alemão contemporâneo Peter Sloterdijk traz o conceito de "antropotécnica"30; no teatro, Stanislavski fala do "trabalho do ator sobre si mesmo" "31; Artaud, do "atletismo afetivo"32; Grotowski, "a arte como veículo" 33 . Todos, de alguma forma, descrevem conjuntos de práticas e estratégias que extrapolam o domínio técnico específico da atividade em desenvolvimento e são determinantes no processo. Referências a formas de cuidados de si também podem ser encontradas muito antes na história e certamente ultrapassam o momento observado por Foucault. Assim, o autor atribui sua escolha por

\footnotetext{
${ }^{29}$ FOUCAULT, 2014.

${ }^{30}$ In: SLOTERDIJK, 2012.

${ }^{31}$ In: STANISLAVSKI, 1989.

${ }^{32}$ In: ARTAUD, 2006.

${ }^{33}$ In: FLASZEN, 2010.
} 
este momento histórico a uma questão, em suas próprias palavras, de "legibilidade do fenômeno":

(...) chega-se nos séculos I-II a uma cultura de si, a uma prática de si cujas dimensões são consideráveis, cujas formas são muito ricas e cuja amplitude, que certamente não representa nenhuma ruptura de continuidade, permite uma análise sem dúvida mais detalhada do que se nos reportássemos a uma época anterior. (FOUCAULT, 2014:282)

As formas de cuidado de si estudadas pelo filósofo francês em sua hermenêutica compreendem a preparação de maneira ampla. Grosso modo, estes processos de conversão envolviam o conhecimento teórico de mundo (Mathésis) e as práticas (Áskesis) através das quais se buscava a virtude. Esta pesquisa se concentra, no segundo dos dois termos. Áskesis envolve da simulação prática do ato a se realizar às diferentes formas de meditação a seu respeito. Acreditamos que estas sistematizações podem nos ajudar a refletir sobre a preparação para a improvisação musical livre para além da repetição de movimentos que, ao atingirem um ideal, serão apresentados ao público ou gravados. Focaremos aqui nos processos e não nos produtos da improvisação. Acreditamos que diversas práticas associadas à improvisação livre podem ser vistas como formas de cuidado de si, e que estas trazem recorrências de ideias antigas de transformação de si, valendo-se de meios e objetivos frequentemente similares. 


\section{Paraskeué}

A ascese estoico-helenística intenta que o sujeito esteja pronto para o que lhe possa acontecer e, graças ao resultado desta sistematização de práticas, o equipa para que possa obter êxito. Este equipamento, fruto da ascese, é fundamental para compreendermos a maneira como estes filósofos pensavam a continuidade das práticas e exercícios na vida do sujeito.

Creio que quase todos sabemos que nem sempre é fácil seguir rumo a uma meta, e que não raro fazemos uso de ferramentas que nos ajudam a continuar. Denominado pelos gregos, paraskeué, este é considerado pelos filósofos clássicos como fundamento da ascese filosófica e deve ajudar o sujeito a seguir no caminho que almeja, a despeito das contingências. Esta ferramenta deve ajudá-lo a colocar em prática aquilo que acredita ser o necessário. É, indica Foucault, "a estrutura de transformação permanente dos discursos verdadeiros... elemento de transformação do logos em êthos." (FOUCAULT, 2014:219)

É por meio da paraskeué que o discurso que se pretende internalizar se torna parte do sujeito. Muitas vezes composta de frases repetidas em voz alta ou por 
escrito, este suporte faz com que os discursos que o compõe ganhem materialidade e tornem-se a prática deste sujeito que se constrói. Esta ferramenta deve ter, segundo os gregos, um caráter de socorro para que o sujeito possa, por meio dela, deixar passar qualquer movimento interno que o desvie de sua trilha.

Visto por um olhar mais musical, a compreensão mais imediata nos remete à aquisição de conteúdos musicais específicos. Este tipo de técnica de si é comum no desenvolvimento de musicistas em diversos idiomas. Em relação aos discursos que circulam, encontramos a sobrevivência de certos gêneros musicais a partir da constante reiteração de aspectos fundamentais destes idiomas como a repulsa a certos tipos de movimento paralelo ou dobramentos desta ou daquela nota. Na prática, o solfejo que antecede a leitura instrumental de uma partitura, ou a repetição de clichês até que se fale fluentemente dentro daquela língua, também parecem ser ferramentas dentro de processos de transformação do sujeito.

Da mesma forma, talvez haja ressonância na maneira com que determinados preceitos de escuta e interação tornam-se parte ativa da ação no mundo de cada improvisador por meio de esforços que envolvem práticas individuais e coletivas. Talvez isso ajude a explicar a aparente necessidade de trabalhos sobre improvisação livre, inclusive este, afirmarem e reafirmarem a óbvia importância da escuta. Em grupos de improvisação, valores são reiterados por meio de leituras e discussões a respeito de escuta, interação, concentração e outros pilares desta prática musical. Acredito que a realização de exercícios e comprovisações que abordam de maneira prática questões tidas como relevantes para certa ética da improvisação livre também pode ser considerada um processo de transformação de logos em êthos.

O transbordar entre a vida fora e dentro da improvisação livre também é comum nesta prática musical. Parece habitual na improvisação livre, a ideia de que os valores não-hierárquicos buscados musicalmente sejam transformados em ação cotidiana fora da sala de ensaio. Voltaremos a este transbordar quando falarmos sobre a vida como obra, ou estetização da vida, e na terceira seção do trabalho. No momento gostaria de falar um pouco mais sobre esta ferramenta que torna a transformação possível. Traduzida por Sêneca por instructio, a palavra paraskeué representa "o que se poderia chamar de uma preparação ao mesmo tempo aberta e finalizada do indivíduo para os acontecimentos da vida." (FOUCAULT, 2014:286) 
Assimilar os discursos que se considera verdadeiros até que sejam parte inseparável de quem os estuda é um processo longo o suficiente para que a determinação e o foco sejam muitas vezes postos à prova. Principalmente porque na maneira de pensar dos filósofos estudados por Foucault, na Áskesis, não há, de fato, um lugar onde se chega. Apenas um processo que envolve toda vida do sujeito.

Por conta da enorme dificuldade desta busca, faz-se necessário algo que proteja o sujeito em seu caminhar. Para isto deve servir a paraskeué, diz Foucault. Este que deve ser o primeiro suporte da ascese estoica, garante que independente das circunstâncias, será mantido o rumo à meta. Para este fim, são adotados exercícios ascéticos que, embora envolvam renúncias e elementos de austeridade, diferem fundamentalmente da ascese cristã no sentido que não têm como objetivo inicial a renúncia de si em prol de uma vida posterior, e sim, a constituição de si mesmo para esta vida. Mais uma vez, o foco é o processo e não o produto final. A vida bela e não a morte honrosa. 


\section{Técnica instrumental, cuidado e conhecimento de si}

Diferente da ascese cristã do final do século XVI e início do XVII que, como descreve Foucault, previa exercícios específicos predeterminados a serem praticados em horas certas, a Áskesis parece sugerir um caminho mais conducente a um sujeito criativo que se adapta mais facilmente a novas realidades. O rigor da predeterminação é preterido, como indica o autor na citação que segue, em nome de um sistema que depende da constante reavaliação de si e de todas as potencialidades do sujeito para que se determine a forma mais adequada de ação a cada momento. A respeito da organização dos exercícios da ascese filosófica Foucault aponta que:

Temos algumas indicações de regularidade. Algumas formas de exame da manhã são recomendadas, exame que se deve fazer pela manhã e que diz respeito às tarefas que devem ser cumpridas durante o dia. Recomenda-se o exercício da noite (exame de consciência), esse, bem conhecido. Mas afora estes poucos pontos de referência, tratase muito mais de uma livre escolha destes exercícios pelo sujeito, no momento em que os julgar necessários. São apenas fornecidas algumas regras de prudência, ou algumas opiniões sobre a maneira de realizar estes exercícios (...) (FOUCAULT, 2014:380).

Observamos esta mesma variabilidade na maneira como musicistas de improvisação livre se dedicam ao desenvolvimento da técnica instrumental. Enquanto há musicistas que se dedicam ao domínio pleno das técnicas tradicionais e à exploração de 
técnicas estendidas, há frequentemente musicistas de improvisação livre que não passaram pelo ensino formal de música e encontram suas ferramentas sem que precisem passar pelos processos tradicionais de desenvolvimento técnico. Não raro, todo seu repertório de sons é composto por técnicas estendidas, mais próximas ao paradigma do som do que da nota, e possuem frequentemente menos vícios de territórios musicais específicos. Ademais a relação entre a luteria experimental e improvisação livre faz com que o ambiente desta prática seja bastante ocupado por novos instrumentos com novas técnicas e novos mistérios.

Para os filósofos estudados na obra de Michel Foucault a questão da técnica é colocada em campo mais amplo e insere-se dentro de uma preparação que embora seja feita por alguém que exerce uma atividade específica na qual intenta desenvolver-se, também deve contemplar uma dimensão ética que visa desenvolver o sujeito como um todo inserido em um grupo. Foucault indica, no entanto, que determinados caminhos foram tomados na história da subjetividade que ressignificaram o cuidado de si em relação à maneira como se apresentava na filosofia clássica.

Esta ressignificação teve por consequência o descarte do cuidado do outro como parte do cuidado de si. Para tanto, eleva-se a um status inédito o conhece-te a ti mesmo, que realiza o improvável e separa-se daquilo que justamente levaria o sujeito ao conhecimento de si, isto é, o cuidado. Este processo certamente transformou a maneira como se compreende o que está, ou não, vinculado ao desenvolvimento do sujeito virtuoso. A técnica, útil e producente, pode então ser desenvolvida sem que se precise acionar todo o sujeito. O cuidado pode concentrar-se no desenvolvimento das potencialidades do indivíduo que tragam maior ganho para si, independente do mundo ao redor. O outro torna-se conveniente, inconveniente ou irrelevante.

Embora não seja aí que surja esta cisão, um momento indicativo deste deslocamento é definido pelo filósofo como o momento cartesiano. É neste período que o autor observa este processo determinante para a estruturação da maneira como entendemos algumas relações éticas entre o que fazemos e o que somos. Não à toa, esta questão recebe especial atenção já na primeira aula de Foucault no curso de 1982. É neste momento que se instaura, como mostra o autor na citação a seguir, o conheça-te a ti mesmo (gnôthi seautón) como princípio fundador do procedimento filosófico: 
Com efeito, e nisso as coisas são muito simples, o procedimento cartesiano, que muito explicitamente se lê nas Meditações, instaurou a evidência na origem, no ponto de partida do procedimento filosófico - a evidência tal como aparece, isto é, tal como se dá, tal como efetivamente se dá à consciência, sem nenhuma dúvida possível... É portanto, ao conhecimento de si, ao menos como forma de consciência, que se refere o procedimento cartesiano (FOUCAULT, 2014:15).

No entanto, esta expressão tão presente em torno do personagem de Sócrates é, neste momento, requalificada filosoficamente em relação ao seu uso e significado original. É deixada de lado sua dependência fundamental do cuidado de si, que para estes filósofos, como vimos, deve contemplar o cuidado do outro. Foucault aponta para o texto Socrático intitulado Alcibíades ${ }^{34}$ onde mostra como a epiméleia heautoû (o cuidado de si) "é realmente o quadro, o solo, o fundamento, a partir do qual se justifica o imperativo do gnôthi seautón (FOUCAULT, 2014:9). Embora esta discussão possa parecer um pouco distante da improvisação, esta compreensão do cuidado, ou as práticas de preparação e transformação, como algo que levado a cabo, envolve toda vida do sujeito também é comum na improvisação livre. A ligação inerente destes processos com a figura do outro sugere um cruzamento estrutural destes universos.

Foucault mostra em Epicteto e outros estoicos tardios que Sócrates é aquele que aborda os jovens na rua e os incita a ocuparem-se consigo mesmos. Dizia o filósofo: “ocupai-vos com tantas coisas, com vossa fortuna, com vossa reputação, não vos ocupais com vós mesmos." (FOUCAULT, 2014:7) O cuidado de si, esta base para o conheça-te a ti mesmo, que previa o envolvimento total do sujeito na busca da virtude é para Foucault:

(...) uma espécie de aguilhão que deve ser implantado na carne dos homens, cravado na sua existência, e constitui um princípio de agitação, um princípio de movimento, um princípio de permanente inquietude no curso da existência (FOUCAULT, 2014:9).

Lembrando que este princípio de movimento deve, segundo a filosofia que antecede esta ressignificação do cuidado de si, impulsionar o sujeito a um cuidado que é sobre todo o seu ser e também sobre os outros. Por meio do cuidado de si, o sujeito deve conduzir-se não a uma regra de vida, mas a uma arte de viver (tékhne tô̂ bíou). Segundo Foucault:

Creio que isso não deve ser esquecido. Fazer da própria vida, objeto de uma tékhne, portanto, fazer da própria vida uma obra - implica necessariamente a liberdade e a escolha daquele que utiliza sua tékhne. Se a tékhne devesse ser um corpus de regra às

\footnotetext{
${ }^{34} \mathrm{O}$ texto Alcibíades é citado por Foucault diversas vezes na Hermenêutica do Sujeito. Neste momento faço referência à aula de 6 de janeiro de 1982, que pode ser encontrada na bibliografia em FOUCAULT, 2014.
} 
quais seria preciso submeter-se de ponta a ponta, minuto a minuto, instante a instante, se nela não houvesse precisamente essa liberdade do sujeito, fazendo atuar sua tékhne em função de seu objetivo, do desejo, de sua vontade de fazer uma obra bela, não haveria aperfeiçoamento da vida (FOUCAULT, 2014:381).

Não são raros os relatos de improvisadoras e improvisadores que se vêm em constante processo de preparação para a vida e para improvisar. Voltamos à retroalimentação entre preparação e ato. Para um grande número de musicistas de IL, toda a vida e todas as práticas que preenchem os dias, meses, e anos estão ligadas à improvisação. E por consequência toda a vida do sujeito é levada para dentro da sala de ensaio. Não há dentro nem fora da vida ou da música. Não existe uma chave que alterna entre viver e realizar seu ofício. Ideias dualistas como estas que cindem o sujeito não servem para esta visão de improvisação livre.

Vimos maneiras como certos musicistas levam éticas que acreditam serem adequadas à interação humana para as relações criativas com outros improvisadores gerando assim uma espécie de devir social-sonoro não-hierárquico. Estes contextos e práticas que talvez possam estar relacionados com o que Guattari chama de revolução molecular. ${ }^{35}$ Ao definir este termo inicialmente como o atrevimento de singularizar Guattari continua:

A tentativa de controle social, através da subjetividade em escala planetária, se choca com fatores de resistência consideráveis, processos de diferenciação permanente que eu chamaria de "revolução molecular". Mas o nome pouco importa." (GUATTARI e ROLNIK, 1996:45)

Em seus ateliers, Chefa Alonso trata, de questões como adaptação, negociação, escuta e reação. As questões éticas que são trazidas para dentro do discurso sobre improvisação livre, são tratadas musicalmente e geram um objeto/fluxo estético efêmero como as relações impermanentes das quais é feito. A construção de uma vida bela, desta arte de viver, parece ser central no discurso de Alonso.

Este mesmo transbordar pode ser visto nos relatos do experimento que realizei com a Orquestra Errante, sobre o qual falarei mais na seção relatos e processos. Pudemos observar que não está ausente a preocupação com o desenvolvimento da técnica instrumental. Embora sejam mais recorrentes no material aqui levantado, contribuições que compreendem a preparação em campo mais amplo, também encontramos relatos que

${ }^{35}$ GUATTARI e ROLNIK, p.45. 
se concentram na importância do desenvolvimento técnico instrumental e domínio das técnicas tradicionais.

Entre os autores que discorrem sobre este aspecto específico da Áskesis, isto é, o desenvolvimento técnico motor, Foucault nos aponta para o trabalho de Demétrius. Este filósofo indica como deve ser o treinamento de um atleta que se prepara para as imprevisibilidades do momento em que suas habilidades serão postas à prova. Porém, antes deste guia para a criação de exercícios, gostaria de voltar rapidamente às propostas de Mary Halvorson das quais falamos no início desta seção.

No vídeo citado, a improvisadora destaca a importância de criar seus próprios exercícios e enfatiza que não precisam ser complicados. Halvorson demonstra exercícios adaptáveis e simples que contribuem para a construção de um vocabulário. Um grupo de ações, do qual se pode dispor. Além da necessidade ressaltada e reiterada pela musicista de incansáveis repetições destes exercícios semiabertos que, como vimos, também é recorrente entre os filósofos clássicos, o exemplo abaixo indica mais uma forte intersecção. Neste trecho, que apresenta semelhanças consideráveis com o discurso de Halvorson, Demétrius prescreve como acredita que devem ser os exercícios do atleta.

(...) alguns movimentos elementares, mas suficientemente gerais e eficazes para que possam ser adaptados a todas as circunstâncias, e para que possamos - sob a condição de serem também suficientemente simples e bem adquiridos - deles dispor sempre que necessário. (FOUCAULT, 2014:286) 


\section{Provas, parrhesía e práticas}

Uma das formas comuns de exercícios da antiguidade clássica se refere às provas. Estas parecem apresentar afinidade com alguns processos de musicistas de improvisação, e diferem fundamentalmente das renúncias e abstinências. As abstinências são algo a que o sujeito se submete periodicamente enquanto a prova "deve tornar-se uma atitude geral em face do real". (FOUCAULT, 2014:387). Outra diferença importante está no fato de que a prova, ao contrário do regime de abstinências, comporta sempre um caráter de descoberta de si. Até onde se pode ir. Como nos mergulhos no desconhecido de um ensaio de improvisação livre que frequentemente levam instrumentistas a encontrar possibilidades sonoras que até aquele momento não faziam parte do seu repertório de sons. Comum também em ambientes de improvisação livre são as discussões coletivas que antecedem e/ou sucedem a prática. Estas revelam formas distintas de compreender este processo de descoberta. No trecho abaixo, Foucault descreve esta prática de subjetivação, isto é, as provas:

(...) trata-se, através dessa espécie de jogo aberto da prova, de demarcar a si mesmo, de medir o ponto de progresso em que se está, e de saber no fundo o que se é... A prova deve sempre estar acompanhada de um certo trabalho do pensamento sobre ele mesmo. (FOUCAULT, 2014:387) 
Ao descrever sua prática com a Orquestra Errante, Rogério Costa, além de reforçar a ideia do ambiente da improvisação livre como heterotópico, oferece uma descrição que parece condizente com as ideias apresentadas por Foucault. Costa diz:

Em termos mais poéticos, pode-se dizer que a Orquestra Errante é uma brecha de espaço/tempo preparada para fomentar agenciamentos sonoros/musicais coletivos, sempre inéditos. Mas, para detalhar, pode-se dizer também que a Orquestra Errante é um campo de provas, de produção e de experimentação. (COSTA, 2016:145)

Cabe ainda falar sobre um conceito fundamental para a compreensão deste trabalho de Michel Foucault e para as relações que estabeleço com a livre improvisação. Trata-se da forma de articulação dos discursos que compõe a paraskeué, isto é, a parrhesía. Etimologicamente, parrhesía significa falar com franqueza, abertura de coração, liberdade de palavra. Este termo, segundo Foucault, refere-se a uma atitude moral, ao êthos e está ligado à decisão, escolha, à atitude de quem fala. A fala sem intenção de convencer. Refere-se à necessidade de se transmitir o discurso verdadeiro. Traduzido para o latim como libertas, este termo parece adequado não só para a improvisação livre mas para boa parte da música experimental de hoje.

\section{Foucault explica:}

É a abertura que faz com que se diga, com que se diga o que se tem a dizer, com que se diga o que se tem vontade de dizer, com que se diga o que se pensa dever dizer porque é necessário, porque é útil, porque é verdadeiro. (FOUCAULT, 2014:327)

Refletir sobre processos musicais improvisatórios sob a luz desta pesquisa de Foucault pode ajudar no olhar para práticas e eventos subjetivos, aparentemente extramusicais, nestes processos. Esta abordagem pode ajudar o pesquisador a fazer perguntas para as quais não seja necessário/possível chegar a soluções. Grupos de práticas que apresentam aparentes semelhanças com os processos descritos pelo filósofo francês podem ser encontrados sem dificuldade na literatura musical.

Charles Mingus narra em autobiografia ${ }^{36}$ como fazia para estudar mentalmente quando estava internado em uma instituição psiquiátrica e não tinha acesso a instrumentos musicais. Robert Fripp tem suas ideias musicais estudadas em livro de Eric Tamm ${ }^{37}$ que descreve a forte influência do pensamento do mestre espiritual armênio

\footnotetext{
${ }^{36}$ In: MINGUS, 2005.

${ }^{37}$ In: TAMM, 1990.
} 
George Gurdjieff sobre o músico inglês. O autor também ressalta a importância da constituição de si através de pequenos hábitos de um sujeito em constante desenvolvimento.

A improvisadora e compositora Pauline Oliveros oferece importante contribuição para estudos sobre práticas de subjetivação associadas à música em seu livro Deep Listening: A Composer's Sound Practice ${ }^{38}$. Suas ideias receberão mais atenção na segunda seção. Nesta, também estabeleço um diálogo com autores que escreveram especificamente sobre a improvisação, no âmbito das ciências cognitivas. Tanto Oliveros quanto Pressing possuem pesquisas nesta área que também se interessa pelas particularidades da preparação e performance de música improvisada.

${ }^{38}$ OLIVEROS, 2005 


\section{Ideias finais da primeira seção}

Improvisar pode ser parecido com andar na corda bamba, como frequentemente descreve o improvisador Robert Levin (BERKOWITZ, 2010). Neste cenário, olhar para o lado ou distrair-se pode ser trágico. A concentração, segundo este paralelo, apresenta-se como habilidade basal para a manutenção do fluxo improvisatório. A improvisação musical coletiva livre permite que diversas pessoas andem em cordas bambas diferentes que se cruzam dinamicamente, formando juntas um fluxo cuja manutenção depende de escuta, concentração, interação, confiança, decisão, energia, silêncio, memória e risco de quantas pessoas houver envolvidas. As constantes alternâncias entre equilíbrio e desequilíbrio, fixidez e mobilidade, territorialização e desterritorialização, por parte de cada musicista e as maneiras como estas linhas interagem, contribuem para gerar um fluxo sempre inédito e irreprodutível.

Musicistas diferentes oferecem relatos variados de como pensam sobre as habilidades que sustentam este fluxo, e como acreditam que suas práticas se relacionam com desenvolvimento delas. Improvisadores que, assim como os filósofos estudados por Foucault, descrevem um cuidado de si para improvisar que supõe um desenvolvimento total e constante do sujeito. 
Ao considerarmos as possibilidades de contribuição advindas destes processos de construção pessoal, deparamo-nos com uma série de virtudes que podem interessar a improvisadores e improvisadoras. Vislumbramos um sujeito concentrado, de escuta aberta, capaz de dizer o que acha necessário na hora exata, e de agir ética e esteticamente em relação a um todo. Espero ter mostrado que voltar o olhar para si apresenta-se frequentemente como processo determinante nesta preparação.

Para os filósofos estudados por Foucault, a busca pela virtude ou verdade, seja na música ou qualquer outro ofício, caminha junto com o processo de construção do sujeito. Afora o desenvolvimento técnico e criativo indispensável, o aprendiz lançará mão de ferramentas e estratégias que o permitirão exercitar continuamente este conhecimento de forma plena. Estas ferramentas supõem um desenvolvimento ético. Para tocar melhor, segundo esta lógica, além de possuir grande conhecimento teórico e prático a respeito do objeto que se pretende dominar, deve-se incansavelmente buscar a internalização de determinadas diretrizes axiológicas.

O processo improvisatório envolve um número incontável de afetos que interagem para gerar um todo, uma música. As formas como nos ensinamos a agir, a não agir e a reagir interferem nos nossos processos de tomada de decisão enquanto tocamos. Junto com outras questões, como a maneira com que eventos externos e conjunturas psicológicas influenciam os rumos do som que se criará, além de atuantes não humanos, podemos observar habilidades que auxiliam de maneira determinante na improvisação. Abrir mão dos próprios impulsos em função do que se ouve, saber dar e receber silêncio, tomar a frente quando parecer apropriado, entre outras, são potências que podem ser desenvolvidas por musicistas diferentes de formas muito variadas, e possuem ressonâncias nas relações fora da música.

Não estamos interessados apenas no treinamento mecânico dos músculos e tendões para que possam estar o mais próximo possível do fluxo de ideias musicais da criação em tempo real. A capacidade de responder a um presente tão volátil quanto o da improvisação livre parece algo que pode ser expandido e aprofundado de inúmeras formas. Pessoas envolvidas com esta busca frequentemente procuram auxílio em atividades que junto com a preparação técnica e teórica, tomam-lhe quase por inteiro os dias e a mente. 
A compreensão da preparação, amiúde, envolve bem mais do que as horas com o instrumento na sala de estudo. São adotadas atividades de meditação e corrida para aprontar os músculos e, também, a mente para longas sessões de trabalho criativo. Estas práticas ensinam mais do que padrões de contração muscular adequados. O projeto musical por vezes funde-se com um projeto de vida e de mundo. Na Áskesis os dias tornam-se parte de um processo continuo de cultivo de si. Penso na dedicação monástica de diversos músicos improvisadores que conheci. Vidas focadas de trabalho, regadas de abstinências e guiadas pela construção de um corpo de possibilidades criativosonoras. 
SEÇÃO II

RELATOS E PROCESSOS 
Esta pesquisa partiu de um interesse por certas questões relativas às especificidades desta preparação musical, que não encontrava na preparação para a execução de música composta em tempo diferido ou em métodos voltados para a reprodução e variação de padrões idiomáticos. As inquietações que habitavam minha própria prática de improvisação encontraram ressonância nas ideias de Foucault, encontradas, por sua vez, em pesquisas sobre processos de preparação e treinamento para teatro e performance. As ideias deste filósofo, bem como relações destas com outras áreas do conhecimento, são tratadas mais diretamente na seção Improvisação livre e cuidado de si.

Aqui me concentrarei em outras duas partes da pesquisa. A primeira da qual falarei refere-se a um experimento prático que conduzi com a Orquestra Errante $(\mathrm{OE})$, no qual foram realizadas propostas relacionadas às questões desta pesquisa $\mathrm{e}$ colhidos relatos das pessoas envolvidas nas realizações. A OE é uma parte bastante significativa da minha prática como improvisador e diversas das inquietações que moldaram esta pesquisa encontram terreno de investigação prática semanal neste ambiente. Assim, acredito que faz algum sentido iniciar esta seção pelo experimento com a orquestra, e permitir que as questões que surgem levem às entrevistas, e que aos poucos sejam todas tratadas. 
Nesta seção, pretendo falar mais diretamente de maneiras como estas questões se encontram em diferentes processos criativos. Procurarei relacionar as ideias vindas das diferentes fontes —entrevistas, experimento e leituras - à minha própria prática, de onde surgiram as inquietações que motivaram este trabalho.

Por ser esta seção majoritariamente composta de relatos de musicistas de improvisação sobre seus processos criativos, é normal que aqui estejam presentes um número maior de termos musicais que podem causar dúvidas a leitores e leitoras de outros campos. Acredito que seja possível a compreensão geral do texto sem estes termos, mas tentei, de qualquer forma, oferecer definições, ora em nota, ora no corpo do texto, para quem possa se interessar. Alguns compositores bastante conhecidos no campo da música surgem como referência e são acompanhados de notas de rodapé que visam aproximar o trabalho de não musicistas.

Alguns dos conceitos filosóficos que embasam esta pesquisa também encontram ressonância nos relatos aqui tratados. Em um esforço de priorizar a fluência das ideias das pessoas entrevistadas, os paralelos estabelecidos com Foucault e outros filósofos são, em geral, melhor explicados em notas de rodapé. Apontarei, nestes casos, a leitora ou leitor para outras seções deste trabalho. Da mesma forma, a leitura destas outras seções deve ser bastante enriquecida pelas experiências que cito aqui.

Os relatos foram colhidos das seguintes formas: entrevistei individualmente Pauline Oliveros, Susan Alcorn e Rogério Costa; com ajuda do improvisador e pesquisador Miguel Antar, entrevistei Chefa Alonso; conduzi um experimento/entrevista em um ensaio da Orquestra Errante. Além da pesquisa bibliográfica, as entrevistas e o experimento, as reflexões desta seção também fazem referência à minha prática como improvisador.

Uma das primeiras dúvidas na escrita desta seção foi em relação à estrutura, ou divisão das partes, pessoas e assuntos. Partir das questões que deram início a esta pesquisa, observar e relacionar as maneiras como as questões foram compreendidas e respondidas nas entrevistas? Ou separar os diferentes relatos e listar as respostas de cada entrevista?

Partir da descrição do experimento com a Orquestra Errante e deixar que surgissem as questões da pesquisa veio como um caminho a ser experimentado, e 
culminou no presente texto. No entanto, como outras possibilidades de organização do material coletado podem ser interessantes para outros propósitos, nos anexos deste trabalho estão as transcrições das entrevistas com Pauline Oliveros, Susan Alcorn e Chefa Alonso. Antes de irmos ao experimento vou falar um pouco sobre estas entrevistas para que se possa entender melhor como surgiram as longas citações que compõem esta parte da pesquisa. 


\section{Os formatos de entrevista}

Elaborei uma primeira tentativa de formato na qual musicistas receberiam um arquivo de texto com uma breve explicação sobre os interesses e o formato da entrevista, e instruções práticas para sua realização. Em seguida, os assuntos que formavam os meus questionamentos foram divididos em cinco grandes tópicos: 1) situações extramusicais; 2) relação vida/obra; 3) dificuldades, ferramentas e virtudes; 4) improvisação e música escrita; 5) perguntas soltas.

No formato inicial, cada tópico continha algumas perguntas e um trecho de texto que poderia ser comentado. A ideia era que a pessoa entrevistada pudesse escolher os tópicos que gostaria de responder e dentro destes, tivesse alguma mobilidade para pensar sobre diferentes aspectos do que estivesse em questão. Este formato, porém, demanda um tempo de leitura que as pessoas nem sempre têm. Estas citações mostraramse mais um empecilho do que uma ajuda. A possibilidade de escolha entre os tópicos e questões também, foi um pouco confusa e fez pouco sucesso. As duas primeiras entrevistadas, isto é, Pauline Oliveros e Susan Alcorn, ainda receberam este formato. Para as entrevistas com Chefa Alonso e Rogério Costa, removi os trechos de texto e as instruções, ficando assim só com os tópicos e as perguntas. 
Como disse, ao todo foram realizadas quatro entrevistas e um experimento. Por contingências digitais e erros de backup, uma entrevista se perdeu. Ironicamente, foi a entrevista com o único homem que sobrara da curiosa "seleção natural" que se colocou sobre esta pesquisa, e que descrevo na seçãofeminismos, cuidado de si e improvisação livre. A entrevista com Rogério Costa foi perdida. Costa, no entanto, além de entrevistado e orientador desta pesquisa, também contribui com boa parte da bibliografia que a compõe e coordena a Orquestra Errante na qual ensaio semanalmente. Portanto seu discurso estará inevitavelmente por toda esta dissertação, das ciências cognitivas às referências ao ciclismo.

Com isso, qualquer tentativa de lembrar o que foi dito, em uma espécie de entrevista imaginária, seria inevitavelmente contaminada pela convivência de ensaios, reuniões de orientação e diversas leituras. Várias respostas me vêm à mente quando releio as perguntas da entrevista. Quase tudo que lembro, no entanto, também sei por outras fontes e por isso é suspeito. Infelizmente o incidente com os arquivos de áudio ocorreu sem tempo hábil para uma nova entrevista, portanto, instalou-se mais uma contingência no processo de pesquisa. Assim, como na improvisação onde às vezes as coisas dão errado, não haveria porque esconder os bastidores deste incidente. Passarei agora ao trabalho com a orquestra. A partir daí, chegaremos às questões, e por fim falarei um pouco sobre cada entrevista. 
O experimento

O experimento com a Orquestra Errante foi realizado em outubro de 2016 e tinha a função de avaliar maneiras como diferentes musicistas de IL se relacionam com o desenvolvimento de certas habilidades tidas por autores e autoras deste campo como fundamentais para esta prática. Para tanto, escolhi uma proposta chamada Rock Piece $^{39}$ de Pauline Oliveros e um exercício de Chefa Alonso ${ }^{40}$, e as adaptei para o contexto e os objetivos desta pesquisa.

Eram dois grupos de quatro musicistas, e cada um executou uma das propostas. As regras foram explicadas, discutidas e reiteradas e após cada execução as pessoas que tocaram responderam às seguintes perguntas: deu certo? O que é dar certo? Teria faltado algo? O que poderia ter sido diferente? Como você acha que a realização do exercício se relaciona com as habilidades que este se propõe a desenvolver em quem o realiza? Estas habilidades podem ser trabalhadas individualmente? Se sim, como? Que

\footnotetext{
${ }^{39}$ OLIVEROS, 1989.

${ }^{40}$ ALONSO, 2014.
} 
práticas da sua vida você relaciona com a sua preparação para improvisar? Os exercícios tinham mais a função de gerar dificuldades específicas, e estimular a reflexão a respeito, do que propor soluções.

Como é considerável a quantidade de material levantada entre as entrevistas e o experimento com a orquestra, tive que fazer escolhas. De outra forma, esta seção seria bem maior do que as outras duas juntas. Com o intuito de preservar o máximo do material, anexei, como disse, transcrições das entrevistas no fim deste trabalho. Com o experimento, no entanto, não fiz o mesmo.

Ao passo que a entrevista mais longa foi a de Susan Alcorn, que durou quase uma hora, o experimento durou perto de três. As múltiplas falas simultâneas e outras comunicações não verbais que escapam ao gravador tornam a tarefa ainda mais árdua. Gravar em vídeo traria detalhes que apenas o som não informa, porém afetaria a dinâmica de grupo também de forma bastante intensa. Uma análise atenciosa acerca dos discursos que compõem esta multiplicidade poderia dedicar-se a diferentes formas de transcrição deste material altamente complexo e provavelmente revelaria dados valiosos sobre estas relações. Contudo a quantidade de trabalho envolvido em tamanha empreitada parece por si só uma pesquisa inteira, com um foco um pouco diferente do que proponho.

Há na OE um hábito que considero excelente. Os ensaios são quase sempre gravados por pelo menos uma pessoa ${ }^{41}$. Como a situação é rotineira, as pessoas não lembram que estão sendo gravadas, e o constante estado de vigilância que frequentemente acompanha estas situações se perde. Naturalmente, no sentido da música produzida, isto também se deve à maneira como o erro é compreendido neste ambiente.

A partir de escutas da gravação do ensaio/experimento, fiz uma transcrição resumida de cada resposta dada às perguntas e a partir deste material selecionei trechos que me chamaram a atenção. Comentários fora das respostas requisitadas, como digressões e interrupções, quando pareceram relevantes, também foram considerados.

Assim como a análise frequentemente diz mais de quem analisa do que da obra, entrevistas tendem a dizer bem mais do entrevistador do que às vezes parece.

\footnotetext{
${ }^{41}$ Outro hábito importante é a redação de atas de ensaio. Aliadas às gravações, estas atas permitem um olhar detalhado para processos criativos em improvisação livre.
} 
Portanto, os relatos que trago aqui não representam a verdade sobre o que aconteceu, ou sobre processos em improvisação livre em geral. E no limite, nem mesmo sobre os processos criativos das pessoas que contribuíram, uma vez que a transformação constante deste tipo de processo já pode tê-los levado para outros lugares. Apresento, nesta parte do trabalho, retratos e leituras destes acontecimentos singulares a partir das relações que estabeleço com as ideias que surgiram de outros e outras musicistas de improvisação. 


\section{Três intervenções em quatro minutos}

A primeira proposta, escolhida foi o exercício da Chefa Alonso. Alonso postula que cada instrumentista tem direito a um total de três intervenções, mais ou menos curtas, que devem ser administradas em relação ao grupo no tempo da performance. Com o intuito de abordar algumas questões em especial, que descreverei a seguir, acrescentei que a execução do exercício deveria durar quatro minutos.

Com isso, cada musicista teria de administrar suas três intervenções em um tecido temporal que certamente ficaria esburacado. Ainda que se optasse, o que não foi o caso, por condensar todas as intervenções em um espaço curto, haveria inevitavelmente a necessidade de espera, silêncio e escuta. Como lidariam com isso? Esta proposta visa evidenciar e trabalhar sobre dois comportamentos bastante comuns na improvisação livre, e certamente nas relações sociais.

A título de ilustração, os chamarei aqui de vai um de nós e instinto salva-vidas. O primeiro refere-se a uma velha história de família segundo a qual, uns amigos de uns tios estavam em uma caminhada por uma trilha estreita quando um deles caiu no rio que beirava o percurso, e se assustou um tanto com a queda. Um dos amigos 
aproximou-se da margem do rio, avaliou a situação com muita calma, voltou-se para os demais e disse: "pô, vai um de nós lá ajudar o cara..." Felizmente o caso não era sério, o rio era raso, e o rapaz conseguiu sair sozinho sem maiores problemas. Pelo menos é como lembro a história. Mas o que interessa aqui é a ligação com aquele momento quando percebemos a necessidade da ação, mas esperamos que a inércia seja quebrada por outra pessoa qualquer, ou acreditamos que as coisas se resolverão sozinhas.

Naturalmente a omissão em um caso real de afogamento seria terrível. Outras relações também podem ser pensadas no âmbito da ação do sujeito em relação ao outro e na sociedade. Contudo, foi apenas uma brincadeira inofensiva entre amigos. Dentro da prática da improvisação esta omissão também existe de várias formas e por vezes se confunde com escuta, espera, silêncio intencional, insegurança, distração, etc. Por este motivo, busquei com esta proposta, investigar os diferentes silêncios de uma improvisação livre e suas relações com a alteridade, concentração, domínio de si e coragem.

Do lado oposto ao "vai um de nós" encontramos o "instinto salvavidas". Outro comportamento comum tanto em grupos de livre improvisação quanto nas outras relações que nos cercam. Durante a entrevista, Chefa Alonso falou sobre o que considera as maiores dificuldades dentro de ambientes de improvisação livre:

\begin{abstract}
O que eu mais encontro ensinando os alunos, o que mais lhes custa é o silêncio, calarse. Há sempre uma angústia, uma ansiedade de tocar, tocar, tocar, tocar, e é normal. Acontece com todos nós. Porque, bom, a gente fica provando coisas, explorando e tal... E essa ansiedade de tocar te leva a não escutar. Então aí eu digo ao aluno: para! Para um momento de tocar e escuta, porque às vezes as pessoas tocam angustiadamente porque geralmente não têm uma ideia. É só tocar por tocar e isso não leva a nenhum lugar. O melhor que pode fazer quando não tem ideias é calar-se porque os companheiros vão te dar ideias, com certeza! Então, cale-se, escute e olhe o que está se passando, e pense "o que posso inserir que vá melhorar o todo". Senão cale-se. Porque também é bom ficarmos calados. $O$ que posso colocar que melhore ou que me apetece em relação ao que está soando. A partir dessa atitude, a coisa vai caminhando. Eu creio que a princípio o mais difícil é calar-se, ou seja, admitir que o silêncio está muito bem e faz parte da música. O contrário também é difícil. Ou seja, tomar decisões como "agora vou eu, vou contar algo que tem relação com o que está passando. Pois isso também é difícil e ficamos pensando: "entro ou não entro..." Tome a decisão e anda, se arrisca! Se sair mal e não funcionar, bem, a vida é assim. Nem sempre é êxito, êxito, êxito. Muitas vezes as coisas não funcionam. Não tem problema. ${ }^{42}$
\end{abstract}

Ter iniciativa é sem dúvida uma habilidade valiosíssima. Ter a coragem e disposição de romper a inércia, saltar a partir do primeiro impulso, preencher

\footnotetext{
${ }^{42}$ ALONSO, 2016. Tradução minha. Revisão de Miguel Antar.
} 
o vazio das ações, etc. No entanto, imagine se, ao invés do vai um de nós, vinte pessoas pulassem no rio para salvar o rapaz. Mas estas metáforas são sempre um tanto estranhas e acredito que situações comuns da improvisação ilustram bem esta ideia. Quem nunca tocou com alguém que é sempre o primeiro, ou segundo, a pular na água? Que efeito isso tem sobre o grupo? Como trabalhamos este instinto em nós mesmos sem cair em omissão?

Estes eram os objetivos e as motivações deste exercício. Trata-se de um exercício difícil que exige grande concentração para equilibrar as ações no tempo, e em relação aos outros, sem permitir que a mente passeie. Esta proposta foi a primeira a ser realizada e o grupo foi formado, por sugestão de Inês Terra, cantora na orquestra, pelas quatro mulheres presentes no ensaio daquele dia. Isto é: Inês Terra (voz), Mariana Carvalho (piano), Mariana Martinelli (saxofone) e Ariane Stolfi (voz e percussão).

A improvisação começa com sons espaçados. Sem pressa, uma ideia ruidosa e pequena surge e desaparece. O mesmo material é retomado, atravessa o tempo, reaparece em lugares diferentes, transforma-se, muda a velocidade, o tamanho do grão, o espectro das cores mais tônicas que escapam ao ruído, e depois voltam para silêncios longos e expressivos, e ações estranhamente coordenadas. Quatro minutos cravados.

Logo após a realização da proposta, as musicistas responderam à algumas perguntas sobre a experiência e uma das questões que teve uma maior variedade de respostas foi sobre as relações que estabelecemos com os silêncios enquanto tocamos. Segue uma transcrição de parte da discussão:

Pedro Sollero: Vocês acham que o silêncio teve algum efeito na sua concentração?

Mariana Martinelli: Sim. Silêncio me causa um sentimento de expectativa, de "e agora?!’. E eu não gosto muito de ter esse sentimento. Eu fico meio confusa.

Ines Terra: a gente sai da inércia, na real. Porque você tem que pensar em som, mas no silêncio.

Mariana Carvalho: o silêncio tem a ver com a concentração quando você escuta ele... isso que faz essa proposta "dar certo ou não dar certo”. Mais do que pensar na intervenção que você vai fazer, pensar em como você vai lidar com esse silêncio. Talvez nesse momento não tocar seja mais importante do que tocar. E a sua conduta durante o silêncio merece mais atenção porque a gente não tá acostumado a fazer isso.

Ariane: pra mim foi legal porque eu fiquei pensando o que eu ia fazer. Eu fiquei planejando. ${ }^{43}$

43 2016. Relatos sobre o a realização do exercício proposto. 
Pauline Oliveros falou, na entrevista realizada, sobre formas diferentes de encarar o silêncio em uma improvisação. Estas ideias podem fazer parte das práticas de qualquer musicista e talvez sejam uma maneira interessante de acolher este elemento tão fundamental da música que exercitamos tão pouco a ponto de temê-lo:

Eu penso que uma possibilidade é tocar com o silêncio. E se você partir do silêncio, então surge a questão de se você é capaz de dar silêncio, além de receber silêncio. Portanto isto é algo que o grupo pode explorar. E se você começar com uma meditação de escuta, então você não está emitindo som. Você está escutando som. Portanto também é importante escutar o silêncio. Caso haja algum. Porque sempre tem algo. Você consegue basear sua improvisação no que está escutando? No que o ambiente está fazendo. Você consegue, em uma improvisação, criar a sensação de que os sons a sua volta estão certos? Isto é divertido. ${ }^{44}$

A questão do planejamento, ou não, dos materiais e ações como parte da preparação para improvisar — além dos ajustes e possível abandono deste planejamento no momento da performance - recebe tratamentos distintos tanto entre as integrantes da orquestra quanto entre as improvisadoras individualmente entrevistadas. Enquanto Alonso prepara, ocasionalmente, estruturas flexíveis e abandonáveis para guiar improvisações solo mais longas, Oliveros busca livrar-se de pensamentos e expectativas, agindo apenas no momento, a partir de uma escuta profunda do ambiente. Sobre este processo Pauline coloca:

Improvisação, na maneira como vejo, tem um leque muito amplo. É como composição. Não tem como dizer "composição" e saber como vai ser. Você só pode pensar que composição é algo que alguém construiu de alguma forma, mas você não sabe necessariamente como será até escutar a música ou ver uma partitura. Assim você talvez consiga se preparar para escutar a composição. Mas se você tem uma ideia preconcebida muito firme do que é uma composição, ou do que deve ser uma improvisação, então talvez encontre algumas dificuldades se a música não estiver de acordo com as suas ideias ou seu processo de pensamento. Portanto, no meu mundo, a preparação é libertar-se dos seus próprios pensamentos e ideias sobre expectativa. Umas das frases que eu evito, que eu na verdade não gosto, é "eu não sabia o que esperar". É uma perda de liberdade porque se você tem uma expectativa de como será ou deveria ser a improvisação, então você não está livre. Então, a primeira parte é como libertar-se deste tipo de pensamento. E na realidade isto significa livrar-se de pensar. Em minhas meditações sonoras, ou "Deep Listening”, chame como quiser, o processo é exatamente o que eu tenho dito. Livrar-se de pensamentos, livrar-se de julgamento, da crítica, da análise. E isto é a preparação para a escuta. E escutar é dar atenção a tudo o que é, qualquer coisa que estiver acontecendo, qualquer som que estiver acontecendo. Qualquer coisa que possa sentir de qualquer forma. Portanto, é abrir os sentidos para receber e tornar-se, de fato, receptivo. Neste tipo de escuta você começa a expandir sua consciência. Na minha abordagem da improvisação, este é o lugar onde eu começo a improvisar, e eu quero ser capaz de permitir que meu corpo, que é bastante criativo de diversas formas, produza os sons

${ }^{44}$ OLIVEROS, 2016. Tradução minha. 
que ele quer produzir. Aí estou livre na improvisação porque estou receptiva ao mesmo tempo em que estou ativa. ${ }^{45}$

$\mathrm{Na}$ resposta que segue, Ines Terra fala sobre seu processo e estratégias para evitar que a excessiva crítica de si se oponham à criatividade. Ines trata também de duas questões fundamentais desta pesquisa. A primeira delas diz respeito às relações entre a vida dentro e fora da improvisação. Em seguida fala do papel dos idiomas musicais no desenvolvimento e preparação de musicistas de IL. Estes dois assuntos serão retomados mais para frente:

Quando o meu corpo está ruim, não dá. Eu sempre parto do corpo. Eu pratico yoga e exercícios de respiração que não são específicos de canto, às vezes. Leituras também, ou de cinema. Esse estudo que a Mariana falou é muito importante, mas na voz, quando você vai cantar algo que você já conhece a harmonia, você tem a referência do arranjo, a referência da interpretação, a referência do timbre do estilo... é muito mais difícil você explorar o seu... você chega muito mais devagar em "qual é o seu canto". E aí, quando você trabalha, e é muito fã de improvisação livre falar isso né (risos), mas quando você trabalha a partir da exploração vocal mais livre, você chega em lugares que você não conhece. Você cria memórias novas. Musculares e de escuta, e disso você começa a procurar outras coisas, ou tenta gravar e nunca mais consegue reproduzir, e talvez depois, a partir disso, você ache aquela forma de cantar uma canção da qual você tinha todas aquelas referências $e$ talvez por não querer estragar aquilo, idiomático você jamais experimentaria. ${ }^{46}$

\footnotetext{
${ }^{45}$ Idem.

46 TERRA, 2016. Relato sobre o a realização do exercício proposto.
} 


\section{Só quem tocou pode falar?}

Uma das regras claramente estipuladas, discutidas e reiteradas para o experimento era de que somente as pessoas que haviam tocado poderiam responder às perguntas. No entanto, todas as outras pessoas da orquestra podiam escolher entre ficar na sala e observar em silêncio, ou sair. Todo mundo decidiu ficar e ao fim das respostas do primeiro grupo surgiu mais um dado interessante desta interação.

Algo que chama atenção ao ouvir um ensaio da OE é que uma parte bastante considerável do tempo de ensaio é ocupado por discussões que variam de produção e burocracia até detalhes das propostas improvisacionais que são levadas ao grupo pelo Rogério ou alguém sob sua orientação. Estas discussões são indispensáveis, a meu ver, para este ambiente de pesquisa, criação e reflexão. O espaço para cada musicista colocar seus pontos de vista é sempre amplo, e neste caso, eu havia impedido simultaneamente o discurso de todas as pessoas que não estavam envolvidas diretamente nos exercícios.

Assim que foi indicado o fim das perguntas relativas à primeira proposta, Rogério comenta: "eu acho bem interessante o que aconteceu agora. Eu em 
silêncio, querendo falar, todo mundo querendo falar, e ouvir só as quatro foi um exercício de escuta, de trabalhar ansiedade...". ${ }^{47}$ Esta mesma ideia é reforçada por diversos integrantes da orquestra. O exercício havia afetado bem mais do que as pessoas que tocavam. As questões que levantara eram relevantes para os outros membros da orquestra que se relacionaram com o som e com as reflexões e questionamento a seu respeito. Parecia um indício de que estes processos de subjetivação transbordam os corpos onde acontecem.

Esta reflexão sugere que a proposta deve ser pensada de maneira mais ampla de forma a compreender o exercício e a discussão que segue também em função de seus efeitos sobre as subjetividades das outras pessoas que esperam ou apenas observam e, no entanto, também lidam com os silêncios e sons de diferentes formas. Em seguida, fizemos uma livre ${ }^{48}$ envolvendo toda orquestra, para dar vasão à necessidade unânime de falar. A música dura treze minutos, termina em risos e é seguida de uma discussão descontraída.

\footnotetext{
${ }^{47}$ COSTA, 2016. Relato sobre o a realização do exercício proposto.

${ }^{48}$ Nome dado a uma improvisação que, diferente de um exercício ou uma proposta com maior grau de determinação, não parte de nenhuma regra.
} 
Rock Piece

Uma das questões que avaliei quando preparei esta atividade foi se permitiria que se repetisse alguma proposta ou determinaria que cada grupo executasse uma proposta diferente. As duas possibilidades pareciam trazer consequências que afetariam a cientificidade da pesquisa. Decidi permitir que cada grupo escolhesse a proposta que gostaria de realizar, assim criando um tipo de vínculo ou desejo em relação à atividade.

A proposta escolhida foi a Rock Piece, de Pauline Oliveros. As instruções que haviam sido brevemente explicadas no início do ensaio, foram repassadas e rediscutidas. Efetuei duas variações sobre a proposta original. A primeira diz respeito à substituição das pedras por instrumentos, que é uma possibilidade indicada pela autora. A segunda trata do deslocamento das pessoas pelo espaço. A proposta original faz uso de pequenas pedras ressonantes, que são bem mais fáceis de carregar de um lado para o outro do que pianos e amplificadores. As recomendações de Oliveros em geral possuem abertura para diversas formas de realização. A musicista insiste na importância de um acordo entre as pessoas que tocam. 
Segundo as instruções de Oliveros, cada musicista deveria, após escutar os pulsos do ambiente, escolher um pulso independente e tocá-lo sem qualquer interpretação rítmica ou acentuação. Apenas o pulso. Musicistas entram ao mesmo tempo, ou de forma alternada, e enquanto ouvem o todo, devem atentar para sua relação com os outros pulsos. Ao perceber-se em relação de múltiplo de dois ou de três, com outro pulso do grupo, deve-se parar de tocar, escutar, e iniciar novamente a partir de um novo pulso independente.

Este tipo de exercício não tem nenhuma intenção em gerar de fato $\mathrm{X}$ pulsos matematicamente distintos mantidos com precisão, ou algo como os cem metrônomos de Ligeti ${ }^{49}$. Metrônomos inclusive se prestam a este tipo de missão com muito mais competência do que seres humanos. O interesse aqui são os constantes processos de ajuste a partir da escuta atenta. Optei por falar o mínimo possível e não compartilhei estas reflexões com o grupo, o que gerou alguma dúvida em relação aos objetivos do exercício que está longe de ser um treinamento de virtuose rítmica.

Após alguma indecisão quanto à formação dos grupos, Rogério sugeriu que o segundo grupo fosse formado por Felipe Fraga, Antonio Goulart, Gustavo Ribeiro e Caio Righi. Definidos os integrantes do grupo, e escolhida a proposta, seguiu-se um momento que durou cerca de vinte minutos que, acredito, ilustra razoavelmente bem minha experiência em grupos de improvisação livre. $\mathrm{O}$ resumo que segue é bastante simplificado. As ações que descrevo são praticadas por diversos integrantes da orquestra em uma sequência polifônica de: reiteração da proposta; discussão da proposta; reiteração dos grupos; mais discussão da proposta; piadas; reiteração da proposta; silêncio e incompreensão; discussão da proposta; começo.

Uma exigência central do exercício parecia intolerável e gerava inúmeras tentativas de desvio e reinterpretação. Tocar apenas um pulso, sem variar a duração ou espaçamento dos sons, parecia uma camisa de força. Foram feitas duas tentativas. Uma primeira com interpretações bem mais flexíveis das regras propostas, e outra mais atenta às regras. Após as duas execuções, os improvisadores compartilharam

\footnotetext{
49 Aqui me refiro à peça Poème Symphonic (1962) do compositor György Ligeti (1923-2006), que foi escrita para dez performers responsáveis por dez metrônomos cada, com auxílio de um regente. Os metrônomos variam em velocidade e quantidade de corda.
} 
suas ideias sobre a experiência. Talvez seja digno de nota que somente no primeiro grupo, todas as perguntas foram respondidas por todas as integrantes. Na transcrição aproximada que segue, por exemplo, só metade do grupo falou:

\begin{abstract}
Antonio Goulart: Eu acho que nessa proposta, primeiro por mexer com pulso, que é uma coisa tão explicita na música, e depois por ser um exercício muito difícil de ser feito, a tendência é que, quando a gente faz isso em grupo, a parte musical seja totalmente esquecida com o intuito de que o exercício/proposta dê certo.
\end{abstract}

Miguel Antar (não aguenta, pede desculpas, e interrompe): Eu acho que é um estopim esse exercício, pra fazer esse pulo, e explorar essa musicalidade dentro do exercício.

Felipe Fraga: é relativamente fácil manter o pulso. O legal é que esse exercício obriga que a sua atenção não esteja em você. Esteja totalmente focada nos pulsos que os outros tão fazendo. Pra manter o pulso você não precisa de tanta atenção assim, em teoria.

\title{
\{Os outros não concordam\}
}

Pedro Sollero: E da primeira pra segunda tentativa?

Todos em quase uníssono: Menos musical! $!^{50}$

Impor regras a um grupo de improvisação livre não é uma tarefa simples. Atrapalha o fluxo, impede caminhos, castra a escuta, frustra a criatividade e devolve quem toca, às ideias de certo e errado, permitido e proibido, que tendem a encontrar poucos entusiastas nestes espaços. A atenção requerida para cumprir estas regras, caso os objetivos não estejam claros, também pode ser motivo de frustração entre musicistas.

50 2016. Relatos sobre o a realização do exercício proposto. 
A palavra

Este desafio de desenvolver ferramentas pedagógicas e criativas para a improvisação livre é encarado por Manuel Falleiros em sua tese de doutorado pela Universidade de São Paulo. Falleiros, um dos membros iniciais da Orquestra Errante, vê na palavra, importante ferramenta para a condução de processos improvisatórios. $\mathrm{O}$ pesquisador e improvisador, que, como Chefa Alonso, também usa o termo ateliê para os laboratórios práticos de sua pesquisa, investiga componentes da livre improvisação como imaginário, criatividade, risco e invenção. Neste processo a palavra serve como disparador para a criação coletiva. Falleiros chama atenção para o caráter não restritivo de um processo desta natureza:

Observamos em nossas experiências práticas que, conforme dissemos anteriormente, a maioria dos exercícios funciona sob um modelo baseado em estabelecer uma restrição para se adquirir uma habilidade específica. Já o uso da palavra, como veremos adiante, extrapolou a característica de um exercício, pois também se prestou como um estopim criativo e para a condução de fluxo com menos condicionamento da ação do improvisador do que outras propostas. (FALLEIROS, 2012:188)

A ideia de não partir de restrições e sim de ferramentas imaginárias propulsoras de ação criativa permite que musicistas de improvisação trabalhem habilidades específicas sem que se sintam cumprindo ordens em um quartel. Por este 
motivo acredito que a palavra, enquanto estratégia criativa, merece mais atenção nos futuros desdobramentos desta pesquisa. Criar exercícios que atuem sobre determinados aspectos da subjetividade - e arcar com a habitual dificuldade/indisposição que musicistas de improvisação livre têm em seguir regras — pode ser facilitado se não houver regras, etapas, procedimentos e sinais a serem seguidos de maneira estreita. Chefa Alonso, em sua entrevista também falou sobre o uso de palavras como disparador criativo para improvisações:

Em geral, me interessa muito mais tocar com pessoas, mas às vezes me propõem tocar solo, eu me preparo. Ainda há muita improvisação, mas preparo a estrutura, a ordem, digo: com sax ou com percussão, a alternância. E preparo também, às vezes, um tipo de material sonoro que me interessa, e por vezes que posso usar ou não, mas na cabeça tenho: "bom, a primeira parte de sax vou fazer uma coisa mais rítmica ou um material mais rugoso ou o que seja, e mudo para na seguinte pensar de outra maneira." E o mesmo com a percussão. Às vezes tenho uma ideia na cabeça como "terra". Como um som de terra. O que me sugere a "terra" dai então faço coisas que me lembram a terra... ou na percussão posso pensar em motes como "ar" ou “campana”... 51

${ }^{51}$ ALONSO, 2016. Tradução minha. Revisão de Miguel Antar. 


\section{Fatores não musicais}

Outra questão que foi recorrente nas discussões que seguiram as propostas do experimento realizado com a Orquestra Errante diz respeito às relações da improvisação livre com práticas e outros fatores não diretamente musicais. As maneiras como encaramos as contingências compõem parte tanto da vida cotidiana como da forma como tocamos. Durante o primeiro exercício, esta habilidade foi apontada como decisiva para a realização da proposta musical. Nas entrevistas, Pauline e Chefa compreendem esta ideia é relacionada a fatores fora do âmbito estritamente da música. A despeito da seriedade das situações que descrevem as duas entrevistadas, ambas apontam para processos criativos que não se despotencializam a partir da contingência. Pauline Oliveros sobre improvisação e Donald Trump:

Eu tento manter isso (improvisação) na minha vida a despeito de se as coisas estão boas ou ruins, digo, agora temos uma situação nacional um tanto difícil em relação à eleição presidencial e há um sentido de perigo de que podemos ter um presidente que não sabe o que está fazendo. Ele é bastante fanático. Pode ser uma situação terrível, caso aconteça, mas temos outras oportunidades, outras possibilidades. Tento assimilar o que está acontecendo e não me... (pausa)... ainda que eu sinta o perigo. Tem tantas pessoas racistas e com atitudes cheias de ódio. Portanto, uma das coisas que aconteceu, eu acho, é que esta pessoa, estou falando de Donald Trump, revelou estas pessoas. Elas estão mais visíveis do que antes. Esta visibilidade dá a você a 
oportunidade de fazer outra coisa e você precisa saber do perigo e o que ele representa. Ou encare, encare de frente. Mas ontem tive um dia ótimo com umas cinco horas de improvisação com mais duas pessoas. Estávamos gravando e foi bom. ${ }^{52}$

Acerca de acontecimentos externos à música e sua relação com a performance, Chefa Alonso comenta:

Eu quando toco ou quando vou começar uma improvisação ou tocar, isto é o que me importa. Estar neste momento. Não sei até que ponto influi, sua situação atual, sua situação política, amorosa, relações de amizade... eи acho que eu consigo. Acho que a improvisação é um pouco isso, estar neste momento. Enquanto isso só tenho alma para escutar o que está se passando, escutar a mim mesma para ver o que disse... com todas as dificuldades, tanto aqui como no meu país, quando chega o momento de tocar eu estou feliz. Todos os meus problemas param. Chega o momento de algo que quero, que gosto. Há quem me pergunte, "mas você não fica nervosa de tocar diante das pessoas? "... ${ }^{53}$ (risos)

Minhas relações com a Orquestra Errante, como disse, se estendem para além deste experimento e há muito mais que eu poderia falar sobre as diferentes experiências que vão de improvisações livres às mais diversas propostas de orientandos e orientandas do Rogério Costa. Este espaço abriga pesquisas de eutonia à síntese instrumental. Todas essas merecem cuidadosa documentação. Fico feliz e me sinto enriquecido de ter participado de alguma forma de algumas delas. A habitual troca de influências, informações, pequenos objetos musicais e acessórios sonoros também parece parte determinante na criação das condições intersubjetivas deste ambiente criativo.

Há certamente material para incontáveis pesquisas sobre a Orquestra Errante, e espero também ler em breve sobre as experiências das quais participei e com as quais aprendi muito. O trabalho de Miguel Antar que desenvolve ferramentas de interação em IL inspirado na figura do clown, os ensaios eutônicos da Mariana Carvalho, os estudos sobre regência em IL de Max Schenkman, as investigações sobre som e espaço de Fabio Martinelli, os exercícios de síntese instrumental de Ramairá Marzola, os experimentos de poesia concreta de Fabio Manzione, todos contribuíram de alguma forma para esta pesquisa e para o meu processo como improvisador. Deixarei, por ora, a orquestra para falar sobre parte do meu próprio processo de preparação e as questões que motivaram este trabalho. A Orquestra Errante, no entanto, é o lugar que alimenta boa parte destas práticas e reflexões.

\footnotetext{
52 OLIVEROS, 2016. Tradução minha.

${ }^{53}$ ALONSO, 2016. Tradução minha. Revisão de Miguel Antar.
} 


\section{O acoplamento}

A relação entre instrumentista e instrumento é parte central tanto na improvisação livre quanto em músicas com maior grau de determinação. Em seu livro The field of musical improvisation, Marcel Cobussen reflete sobre estas relações a partir de ideias já encontradas no campo da música e apresenta visões distintas.

De um lado, o autor traz a ideia bastante comum, e defendida por Pelinski e LaBelle, de que esta relação se trata de uma simbiose, uma ressonância que parece integrar sujeito e objeto, instrumentista e instrumento. Do outro lado está a ideia de que o instrumento não desaparece neste processo e sim oferece uma resistência cujo esforço necessário para superar é de onde resulta a música. Visão esta, defendida por Evens. Em uma espécie de conciliação das duas propostas, Cobussen cita o saxofonista Evan Parker sobre o conceito de biofeedback que parece descrever bem processos em improvisação livre:

Você se envolve com o instrumento e ele te ensina tanto quanto você o diz o que fazer. Portanto, você é sensível [...] a como ele responde aos seus esforços para controlá-lo. Por meio da escuta de como o som volta para você, você aprende a controlar o instrumento melhor. Portanto é um processo muito dinâmico e sensível [...] E o instrumento, ao mesmo tempo, parece fornecer informação adicional. Portanto há 
coisas que você tem sob controle, mas de vez em quando algo vai dar errado. Você perderá o controle. Neste momento, você recebe a oportunidade de aprender alguma outra coisa que o instrumento sabe fazer [...] O saxofone tem uma densidade, um desejo e intenções nas relações que estabelece com você. E você começa a achar difícil distinguir você mesmo e suas intenções, das intenções do instrumento, ou digamos, eu achei difícil. (COBUSSEN, 2017:122) (4 $^{54}$

Nas maneiras como desenvolvemos estes acoplamentos encontramos diferentes características que ora favorecem o processo criativo, ora o tolhem. Ao falar sobre as relações entre música escrita e música improvisada, Alonso falou, no trecho da entrevista que segue, sobre diferentes maneiras em que a formação musical tradicional afeta as pessoas que chegam aos seus ateliês e problematiza a questão do ensino tradicional dos conservatórios em relação a práticas criativas:

Chefa: Quanto mais você sabe, melhor. Tive uma formação acadêmica. Estudei em conservatório, estudei escalas, partituras, etc. agora, eu como professora, muitas vezes tenho isto que você disse, tenho gente com uma formação instrumental impressionante... ou seja conseguem tocar muito bem, e gente que vem da rua, que são autodidatas e que não leem, e gosto muito de juntá-los. Da mesma forma que gosto de juntar pessoas de disciplinas diferentes é ótimo. Não só músicos, mas outras pessoas, porque efetivamente é o que você disse. Os dois mundos são muito ricos $e$ um alimenta ao outro. Portanto o que planejo para mim e em todas as minhas propostas, é possível que convivam estas duas personalidades. Minhas propostas podem ser feitas igualmente por alguém que tem um grande nível instrumental, e sabe ler, sabe escalas e pessoas que não. Eu trabalho sobretudo com o som e um pouco de interação e escuta, esse tipo de coisa. E de fato, o que mais se dá no ensino tradicional, é essa base nas escalas, no pensamento tonal, etc. Eu estou um pouco cansada disso. Não digo que não gosto. Em determinado momento eu também estudei escalas, às vezes, mas isso é o que tem o ensino normal. Com meus alunos que sabem tudo isso, eu procuro que eles se esqueçam disso, e pesquisem mais o som. Assim, minhas propostas eu as pensei para que possam ser realizadas por pessoas com muito nível técnico e também pessoas com pouco nível técnico. Inclusive não músicos... dançarinos, poetas, pessoal de circo... da cena... acho que isso enriquece todos, aprendemos muito mais assim.

Miguel: tenho muitas vezes a sensação de que o excesso de técnica e conhecimento aprisiona a pessoa e é nesse ambiente da improvisação livre que buscamos a liberdade, justamente....

Chefa: De fato, nas minhas aulas tem muita gente com formação clássica, mas estão frustrados porque não há conexão entre sua alma de músico e o instrumento que tocam. Também por esse ensino convencional, frustrante e castrador... pelo menos no meu país, nos conservatórios, é uma técnica que está longe das necessidades expressivas do que estudam... tem gente que vem a minhas oficinas e não quer tocar o instrumento que eles aprenderam no ensino tradicional. Eu lhes digo que não precisa começar tudo de novo, que está bem saber tocar o instrumento. Que é uma questão de liberdade. Que se trata de saber administrar essa técnica tão boa que eles têm, ao serviço daquilo que eles querem tocar... Nos conservatórios não tocamos música contemporânea. E sobretudo, que eu creio que seja fundamental, nos lugares em que se ensinam disciplinas artísticas, não se pode esquecer da criação, da criatividade, e se esquecem. Nos conservatórios se esquecem. Não estimulam às pessoas a compor. São todos como se fossem maquininhas de interpretação de um

54 Tradução minha. 
repertório muito concreto. A "música", a música clássica. Bem, é uma música europeia de três séculos concretos ou dois. E a música é muito maior e muito mais, não? O que mais me deixa brava... que na música, é considerado um bom músico aquele que toca muito bem Beethoven... Mas não podemos esquecer que... Um pintor também aprende copiando grandes pintores, mas um pintor se é importante é pelo que ele põe de novo, de adição ao mundo, não? Por outro lado, na música, um bom músico é quem toca Beethoven. Beethoven está morto há quanto tempo? Um bom músico é aquele que muda o mundo por sua forma de entendê-lo e entender a música. E aí seguimos jogando. ${ }^{55}$

Em outra parte desta dissertação eu falo da capacidade que certas formas de estudo, altamente dedicadas à aquisição de determinados idiomas, têm de viciar a escuta, viciar a ação e dificultar a produção de sons que não os destes idiomas. Falo também, e reitero aqui, que musicistas de improvisação livre que não passaram por um estudo formal e tradicional de música, são frequentemente mais livres para explorar sonoridades fora da gama de sons ditos corretos de seus instrumentos.

Contudo, existe uma sensação mágica de ter o instrumento debaixo dos dedos, associada ao estudo diário do instrumento que, além de criar padrões a serem desconstruídos, permite níveis de expressividade e envolvimento bastante altos e geradores de grande prazer e sensação de liberdade. Um livre falar que pode ser comparado à parrhesía $a^{56}$ dos gregos. Uma transformação na relação com o instrumento que só acontece por meio de trabalho intenso. Porém trabalhos intensos frequentemente deixam calos grossos nas mãos e as endurecem. Parte da preparação para a improvisação livre parece estar na relação entre as habilidades adquiridas nestes trabalhos e a remoção destes calos que libera o movimento.

A construção desta tékhne sem os tijolos idiomáticos ganha novos contornos com a inclusão de incontáveis técnicas estendidas e o constante aparecimento de novos instrumentos. Cada musicista deverá encontrar, dentro de sua singularidade, seus interesses, suas experiências, seus desejos, suas práticas, etc. Caminhos que estarão, como o sujeito que os trilha, em permanente revisão e transformação. Susan Alcorn coloca sua experiência em relação ao desenvolvimento da técnica instrumental:

Houve um tempo em que, na relação com o meu instrumento, eu tocava somente guitarra preparada, em outras palavras, somente técnicas estendidas. E agora estou me esforçando para conseguir tocar o meu instrumento sem técnicas estendidas. Dito

\footnotetext{
55 ALONSO, 2016. Tradução minha. Revisão de Miguel Antar.

${ }^{56}$ A palavra parrhesía foi, segundo Foucault (2014), traduzida para o latim como libertas e para o francês como franc-parler (franco falar). Segundo o autor, esta noção refere-se tanto "à atitude moral, ao êthos," quanto ao "procedimento técnico, à tékhne" (FOUCAULT, 2014:334). Mais reflexões sobre esta noção no ambiente da IL podem ser encontradas na primeira seção deste trabalho.
} 
isso, você mencionou a pedra. Comigo é um pedaço de ardósia que achei em um beco perto do apartamento onde moro. Tenho uns dois ou três pedaços, e o que gosto de fazer com eles é pegar uma chave de fenda minúscula e percorrer partes diferentes da pedra, as quinas e coisas assim. Penso que não estou produzindo isto. Este pedaço de ardósia ou rocha está contando sua história e talvez eu esteja participando tornando isto musical. Assim como uma corda ou o seu instrumento contam as suas histórias. O processo precisa de você, mas você não está no controle. Você torna-se parte do processo. E eu acho que esta é uma distinção importante. Quando eu prático técnicas estendidas, que é menos do que eu deveria - talvez depois dessa conversa eu pratique mais - mas eu tento descobrir o quê de musical eu consigo controlar de alguma forma. "Quando eu faço isso, isto acontece" e não "esta nota é Lá". Este som sai quando faço isto, aquele som sai quando faço aquilo. Isto é o que você tem com você quando usa técnicas estendidas. Na semana passada fiz uma apresentação com uns improvisadores excelentes. Fiquei muito impressionada com a destreza com que tocavam seus instrumentos, e com as técnicas estendidas que usavam. Uma flauta e um violino, então eu fiz coisas com harmônicos e cordas. Tocando cordas soltas e conseguindo harmônicos e parciais. E isso é algo que considero uma técnica estendida que você consegue usar e controlar minimamente. Digamos que você está tocando guitarra e não está encostando no traste, embora eu não tenha trastes, e você quer o harmônico do décimo primeiro traste. E você tem o décimo segundo traste, que é a oitava, mas quando você chega no décimo primeiro, é bastante difícil fisicamente. Eu acho bem difícil tirar esse harmônico. Você tem que palhetar certinho. A palheta precisa estar no lugar certo. O dedo precisa estar exatamente no lugar certo, e precisa saber quando soltar a corda, quando encostar na corda. Digamos que você ataca a corda e coloca o seu dedo sobre ela para conseguir esta parcial. Como você faz isso? Como você faz isso com a palheta? Como você faz isso e depois se move para outra nota? Como isso muda as coisas? Existem inúmeros caminhos musicais e você não pode controlar tudo, e isto é parte da beleza. Não é controlável. É algo que não é cem por cento decisão sua. Você se surpreende, certo? Eu penso que quanto mais controle você tem - e eu estou falando de controle depois de ter falado de ser parceiro do seu instrumento - mas eu penso que quanto mais você, enquanto indivíduo controla as coisas, mais coisas excitantes e descontroladas podem acontecer. Porque você sabe os caminhos, você tem uma espécie de mapa, um mapa corporal de como você faz essas coisas. ${ }^{57}$

A minha formação musical, como tantas outras, teve como material musical a nota e não o som. As técnicas estendidas, em muitas escolas de música, se limitam a explorações mínimas de sonoridades usadas aqui e ali de maneira alegórica, por poucos compositores, sem muito desenvolvimento ou aprofundamento. O contato com o trabalho de guitarristas de improvisação livre - Susan Alcorn, Fred Frith, Keith Rowe, Masayuki Takayanagi, Bill Horist e outros - foi determinante no sentido de compreender o acoplamento guitarrista/guitarra como algo que começa no corpo do instrumentista, vai até o alto-falante, e pode sofrer ação criativa em qualquer ponto desta cadeia. Esta pesquisa constante com diversos materiais, equipamentos e formas de fazer som com a guitarra está relacionado a outra prática de subjetivação que acompanhou esta pesquisa, isto é, as caminhadas.

${ }^{57}$ ALCORN, 2016. Tradução minha. 
Andava pela rua olhando para baixo procurando texturas e materiais que pudessem excitar os captadores de maneira interessante. Este processo era uma espécie de caça sem alvo certo. Pensava ou ouvia sons quaisquer e tentava imaginar o que poderia fazer para que aquele som saísse do meu amplificador. Ou achava algum objeto que parecia oferecer possibilidades sonoras interessantes.

O que seria necessário bater, esfregar, apoiar, encostar, segurar, soltar, etc. Plástico, metal, madeira, vidro, borracha, rugoso, áspero, cortante, granulado, constante, cíclico, saltitante, regular, caótico... tudo isso muda o som. Cada objeto achado ou ganhado, com sua forma e história, ganha uma nova vida. Um caninho de chuveiro vira um capo de altura média, baixa possibilidade de variação de massa, espectro fechado e decaimento rápido; um pente vira uma forma de carrilhão e precisa de todos os seus dentes; um potinho de maquiagem torna-se uma espécie de sintetizador granular. A guitarra torna-se irreconhecível.

Conheci o trabalho de Susan Alcorn por meio de pesquisas de internet sobre técnicas estendidas em guitarra e fiquei interessado pela estória (e a história) das pedras. No vídeo ${ }^{58}$ que vi, ela mostra a maneira como usa musicalmente o pedaço de ardósia que encontrou próximo à sua casa. A guitarrista explica como cada pedra é única, e chegou a este estado pela ação singular do tempo desgastando e quebrando, e imprimindo uma história material que pode ser lida metaforicamente pelo tato amplificado deste devir musicista-pedra-cordas-captador-amplificador.

A partir dessa história comecei a usar pedras diversas e experimentar outras maneiras com que estes objetos podem excitar as cordas. Percebi que certas superfícies, e certos formatos de pedra, não emitiam sons que me agradavam, ou com os quais eu conseguia interagir. Pedras muito lisas não oferecem as resistências que enroscam no objeto que a fricciona e vibra as cordas com sua passagem. Pedras lisas e arredondadas, por sua vez, tem mais dificuldade para ficarem paradas. O constante balanço de um lado para o outro faz com que as cordas sejam excitadas de maneira reiterada e alternada com leves transformações de altura a cada balanço. Segurar a pedra com a mão e friccioná-la contra as cordas também funciona e gera ainda outro som talvez um pouco mais agressivo, na maneira que eu normalmente faço. Enfim, as explorações

${ }^{58}$ https://www.youtube.com/watch?v=TkR_GsyGs24 
são infinitas, mas cabe avisar que para que a pesquisa possa se dar com alguma liberdade criativa, foi necessário separar uma guitarra somente para técnicas como esta.

Esta pesquisa sonora parte da ideia de poder interferir em qualquer lugar do instrumento que é pensado de maneira a incluir outros fatores além da guitarra, como cabos, pedais, processamentos, amplificadores, etc. Outras duas desterritorializações que se deram em relação à guitarra como normalmente a encontramos, se referem à opção por um instrumento sem trastes e à escolha das cordas.

A afinação tradicional da guitarra, mi-lá-ré-sol-si-mi, tem amiúde, uma considerável mudança de timbre entre as cordas agudas e as graves, normalmente entre a terceira e quarta. Para conseguir uma mudança de registro menos acentuada substitui as 3 cordas mais agudas por cordas mais grossas e graves. Para acentuar a lisura trazida pela ausência de trastes, optei por cordas encapadas, frequentemente usadas em guitarras de jazz. Com isso a afinação tradicional é impossível. Sendo assim, uso outros critérios de afinação que variam de acordo com a sonoridade que desejo.

Outra consequência da ausência de trastes é que as cordas perdem energia muito rapidamente e faz com que qualquer som que se pretenda mais longo do que poucos milissegundos, precise ser ininterruptamente reiterado. Este fator também foi determinante na escolha pelos bordões. Este termo, frequentemente utilizado na música popular para se referir às três cordas mais graves do violão, é definido da seguinte forma pelo Dicionário Grove de Música:

Termo usado para indicar uma corda ou tubo que emite um som prolongado, habitualmente grave, que pode ser mantido continuamente ao longo de um trecho musical, como num registro de pedal dos órgãos. São também exemplos as cordas mais graves de vibração livre dos alaúdes maiores (como a tiorba); o som remanescente (zumbido) de grandes sinos; as cordas graves da viela de roda; as cordas capeadas dos violões; as cordas mais graves de um piano; os tubos de som grave das gaitas de foles; e as cordas acopladas à membrana inferior de certos tambores. (GROVE, 1994:122)

Embora a descoberta do verbete tenha sido posterior à composição de minha atual palheta de sons, todas as acepções descritas acima dialogam com sonoridades buscadas por esta escolha de cordas. Outra consequência desta escolha é que para produzir sons um pouco mais agudos, dependo de técnicas como excitar as cordas bem próximo ao cavalete o que dificulta bastante a construção de uma música baseada em notas. 
Mais um fator que me levou a optar pelos bordões foi a possibilidade de construir o meu discurso em uma região de frequências pouco ocupada por guitarristas em geral. Desta forma fica mais fácil a interação e criação de naipes (uma experiência bastante excitante e inédita na minha vida até a OE), uma vez que além de sair do caminho das outras guitarras, faço uma ponte com os sons do contrabaixo devida a extensão que as cordas mais grossas permitem. Assim, a orquestra ganha outras alternativas de cordas graves, e eu ganho possibilidades de ação fora do espaço frequencial mais concorrido do grupo. 
Passo agora a uma questão que não surgiu diretamente nas discussões do experimento com a $\mathrm{OE}$, mas que não é menos relevante, a saber, as relações de cada musicista com o tempo. Mais especificamente, com a duração das improvisações. Esta foi uma das inquietações que acompanharam esta pesquisa desde o início e foi tratada em todas as entrevistas. O motivo desta inquietação, para mim, está bastante ligado às dificuldades de se ficar em silêncio e dar espaço às outras vozes do grupo.

A padronização da escuta em peças curtas — determinada em boa parte por forças não propriamente musicais — também está associada a uma forma de produção na qual todas as decisões de que vozes soarão, são tomadas por uma só pessoa que decide pelo todo, em função do seu desejo de forma. Abre-se mão da liberdade em favor da certeza. Ou seja, um arranjador, ou compositor, pode se dar ao luxo de guardar as cordas para esta ou aquela parte da música, pode deixar a bateria somente para a hora do solo de guitarra, pode equilibrar como quiser a palheta de sons à sua disposição. Ainda que seja numeroso o grupo de musicistas, e a peça dure os costumeiros três a cinco minutos, é certo que todos tocarão e dificilmente haverá grandes surpresas quanto ao papel de cada 
instrumento. Ainda que estes papéis reproduzam padrões hierárquico musicais um tanto limitantes.

$\mathrm{Na}$ improvisação livre este processo acontece de maneira diferente. As decisões são tomadas a todo tempo, e as relações são sempre inéditas e impermanentes. Qualquer tentativa de prever a forma geral, ou projetar para si um espaço no futuro da música em devir tem poucas chances de se concretizar. Quanto maior o número de musicistas, maior a multiplicidade de caminhos que surgem a todo tempo, se agenciam e se dissipam. Um pequeno deslize que gere um som não intencional, ao encontrar a escuta do grupo, pode se desdobrar e transformar-se em linha central do fluxo, de forma rápida e natural. Costa fala sobre este processo:

Nas improvisações coletivas surgem também elementos imprevisíveis que vão condicionar todo o presente da improvisação. São os "erros", as sensações inesperadas e as surpresas com as respostas imprevistas dos outros músicos. Esses são elementos que tem potência de primeira vez e que fazem surgir linhas de fuga que dinamizam o presente. (COSTA, 2016:76)

Estas características da IL, quando enquadradas em uma duração mais próxima à da indústria musical, muitas vezes em uma tentativa de facilitar o trabalho do público, encontram também algumas questões que merecem atenção. A ansiedade para achar um lugar para si, e o tempo que certas coisas levam para se desenvolver fazem com que inúmeras situações de grande intensidade, sequer cheguem a se esboçar. Adotar os determinados padrões porque parece mais próximo ao que o público está acostumado, e partir do princípio de que é isso que as pessoas preferem, parece um comportamento perigoso.

Certas energias surgem do acúmulo, do cansaço, da imersão. As propostas e improvisações curtas podem ser de enorme valor e interesse se não forem a única possibilidade. E principalmente, a meu ver, se não as tomarmos como o tempo de performance padrão. Outras culturas musicais, como indiana e balinesa, tocam por horas sem parar. $\mathrm{O}$ que haveria nestes processos que poderia interessar a práticas de livre improvisação? Que outras pesquisas sobre processos criativos em artes poderiam ajudar nesta busca?

Renato Ferracini, no artigo O Treinamento Energético e Técnico do Ator, fala sobre a formação e preparação do ator dentro de um processo de descoberta que envolve o acesso a diferentes formas de energia por meio de um trabalho físico realizado 
em seções intensas, bastante longas e ininterruptas. Este trabalho é capaz de revelar qualidades do ator que de outra forma não surgiriam. Ferracini conta:

O trabalho de treinamento energético busca "quebrar" tudo o que é conhecido e viciado no ator, para que ele possa descobrir suas energias potenciais escondidas e guardadas. E como conseguir isso? Luís Otávio Burnier, criador do LUME, embasado nas pesquisas de Grotowski, acreditava que a exaustão física poderia ser uma porta de entrada para essas energias potenciais, pois, em estado de limite de exaustão, as defesas psíquicas tornam-se mais maleáveis. (FERRACINI, 2012:95)

Ainda que eu seja bastante favorável às discussões que antecedem e sucedem cada criação sonora dos ensaios de improvisação que frequento, acredito que há outras possibilidades que podem contribuir para estes processos. Com isso em mente, interessei-me por saber o que cada musicista que entrevistei compreendia como "uma improvisação longa". Mais interessado em saber o que estas pessoas pensavam sobre esta prática, evitei dar detalhes das angústias que me ocupavam neste sentido. Cada musicista ofereceu uma visão distinta.

Para Rogério Costa, as improvisações mais longas, em geral, costumam durar em torno de vinte minutos. Embora ocasionalmente façamos na OE livre improvisações que chegam a mais de quarenta minutos.

Chefa Alonso busca restringir a duração de suas improvisações em uma preocupação declarada com a atenção do público. Contudo, vale citar que, como mostra a citação seguinte, esta duração reduzida ainda é pelo menos dez vezes maior do que o limite superior da indústria. Alonso responde:

Normalmente não quero que supere os cinquenta minutos. Tanto por nós que participamos da improvisação como pelo público porque este tipo de música normalmente exige também um público muito especial e atento. E é um esforço também para o público estar ali pendente de tudo o que está passando. Creio que em improvisações muito longas chega um momento em que as pessoas perdem a atenção ou o interesse. Então normalmente, quando há concertos, não mais de cinquenta minutos. Creio que aí está um pouco o limite da atenção do público e também dos músicos. Também é cansativo improvisar, ou seja, estar compondo a todo momento por muito tempo. Eu creio que cinquenta minutos é o máximo. Para uma improvisação sozinha, também acho muito cinquenta minutos, até quarenta está bom. ${ }^{59}$

Pauline Oliveros, que possui uma prática bem mais próxima a culturas orientais, realizava suas oficinas de Deep Listening processos imersivos que colocavam

${ }^{59}$ ALONSO, 2016. Tradução minha. Revisão de Miguel Antar. 
em jogo outras formas de se compreender o tempo e as durações, como mostra a próxima citação:

Doze horas, vinte e quatro horas, doze horas direto, já fiz isso. Não recentemente, mas já fiz. Já fiz solo, mas também já participei de improvisações desta natureza em grupos. Mas eu diria que são basicamente direcionadas para "deep listening” ou meditações sonoras. ${ }^{60}$

Diferentes relações com o tempo inspiraram importantes compositores do século XX como John Cage, Karlheinz Stockhausen e Olivier Messiaen, e continua a inspirar trabalhos no século XXI. Sobre a maneira de compreender o tempo de Messiaen, o compositor Silvio Ferraz apresenta uma visão que parece mais próxima à acepção de Oliveros:

O fim do tempo é o fim da música regida por Chronos. Assim Messiaen põe de um lado o tempo medido de Chronos (tempo cronológico) de outro o tempo vivido da duração; de um lado começo-meio-fim, o tempo sucessivo, de outro o sem antes nem depois a retirada da pertinência da relação causa-efeito. (FERRAZ, 2014:2)

Podemos também relacionar esta capacidade de perceber os finais com a ideia de Kairos — o tempo oportuno da ação — descrita por Villavicencio em artigo chamado The Rhetorical Side of Free Improvisation. Além do tempo de Chronos, aquele que fatia a existência e leva nossos dias em porções regulares, há formas de tempo que não cabem em nenhum metro. O ponto do brigadeiro, colheita da planta, o fim da música. Chefa Alonso fala sobre as dificuldades da improvisação livre:

E outra coisa que lhes custa são os finais. Os finais também precisam ser ouvidos. Eles aparecem. Não os tem que fazer. Às vezes você tem que fazer, mas às vezes não precisa fazer mais do que escutá-los. Às vezes há um final, e porque segues tocando? Mas isso também tem de ser aprendido. É normal. Deve-se ter também o ouvido para dar-se conta de que acabou. Às vezes é muito obvio mas deve-se aprender a escutar. Isto também é uma dificuldade importante. Eu creio que são as três maiores dificuldades. ${ }^{61}$

Também relacionadas à ideia de um tempo oportuno da ação, Susan Alcorn reúne algumas das ideias das outras fontes deste trabalho no sentido que também associa o tempo da improvisação ao da experiência. Sobre as improvisações longas, Susan responde:

Não sei se posso responder porque você está falando sobre tempo e eu acho que o tempo é flexível de algumas formas. O tempo segue em frente, e envelhecemos, e morremos, e depois de um tempo temos que comer, mas o tempo, em relação à música,

\footnotetext{
${ }^{60}$ OLIVEROS, 2016. Tradução minha.

${ }^{61}$ ALONSO, 2016. Tradução minha. Revisão de Miguel Antar.
} 
é como o experimentamos. Se você está no consultório do dentista para remover um dente, três segundos podem ser... e se você está fazendo algo que realmente gosta... em outras palavras, a maneira como você vê o tempo, como você experimenta o tempo, é fluida, é flexível. Em uma improvisação, se as coisas estão mágicas, como às vezes são, e não sei se passaram-se vinte, trinta, quinze os sei lá quantos minutos. As questões com a improvisação livre são: como começar, quando começar, quando e como terminar. E eu acho que isso é uma coisa não dita, sabe? "Ok, é agora que termina."

As maneiras de compreender o tempo dentro da improvisação são inúmeras e não serão esgotadas aqui. Ressaltarei, no entanto mais um cruzamento entre as ideias reunidas nesta pesquisa. Tanto Rogério Costa quanto Pauline Oliveros veem no momento da improvisação, a coexistência do presente, passado e futuro. Segundo Oliveros:

Conforme eu descobri e trabalhei com delays, passei a considerar o meu EIS ${ }^{62}$ como um modelo bastante simplificado de como o cérebro trabalha. $\mathrm{O}$ som tem início no que consideramos o momento presente. Este som volta no futuro; quando volta, é parte do passado. Assim, estou improvisando no passado, presente e futuro simultaneamente. Somos feitos de delays temporais, de nano e pico-segundos até anos e toda a nossa vida. A coordenação de trilhões de delays temporais faz a improvisação, e torna possível improvisar uma composição, ou compor uma improvisação. Assim, o corpo não verbal informa a mente verbal e vice-versa, eliminando a dita cisão entre corpo e mente. (OLIVEROS, 2016:88) ${ }^{63}$

Em seu livro Música Errante, Costa aponta para diferentes sínteses de tempo presentes na improvisação livre e reflete sobre o desejo como fator que está no presente, porém é determinante no sentido de impulsionar a performance para o futuro. A síntese do passado, descreve Costa:

...se dá através da memória de elementos representáveis e abstratos (tais como vocabulários, léxicos, sintaxes, códigos, identidades, estruturas de musicalidade, sistemas de referências, procedimentos, etc.). Esse passado é presentificado, manipulado e entra em jogo de acordo com os rumos da performance em tempo real. (COSTA, 2016:78)

Sobre estes elementos abstratos, Costa afirma logo adiante:

De fato, o jogo da livre improvisação se dá em um plano de intensa interação e contaminação entre territórios, ou seja, os vários territórios que constituem as biografias musicais de cada músico se interpenetram e ressoam um no outro de maneiras imprevisíveis. (COSTA, 2016:78)

\footnotetext{
${ }^{62}$ O EIS (Expanded Instrument System) é como Oliveros se referia ao acoplamento de seu acordeom e processadores de sinal (mais tarde substituídos por computadores), que utilizava em suas performances. 63 Tradução minha.
} 


\section{O passado musical}

Com as duas últimas citações entra em jogo a última questão desta pesquisa, sobre a qual falarei a seguir: $O$ passado musical de instrumentistas de improvisação livre, e as relações entre as maneiras com que as preparações para música escrita, e música improvisada se influenciam nos processos das pessoas entrevistadas.

Susan Alcorn descreve a maneira como compreende estas relações:

Acho que ambas se influenciam (improvisação e música escrita). Não sei se consigo descrever, mas qualquer habilidade que você precisa para tocar música improvisada, no fundo, são as mesmas que você precisa para tocar uma peça composta. Quantas maneiras existem de tocar esta composição? Infinitas. Infinitas coisas pequenas que você pode fazer. Nos últimos anos, quando toco solo, toco bastante improvisação e daí toco algumas peças que eu escrevi, e daí toco, talvez, um Messiaen, ou um Piazzolla. Com o Piazzolla, toda vez que toco é diferente, eu ouço diferente. Toda vez, surgem emoções diferentes. Não que emoções sejam necessariamente boas ou ruins. Eu só sinto diferente, e até coisas minúsculas que você pode fazer enquanto musicista, sem sequer pensar a respeito. Sem pensar conscientemente "Ok, vou tocar esta nota, desta forma”. E estas são habilidades da improvisação que talvez levemos para o trabalho com música escrita. ${ }^{64}$

${ }^{64}$ ALCORN, 2016. Tradução minha. 
Pauline Oliveros aponta na entrevista para algumas diferenças entre processos de improvisação e música escrita e indica que os territórios musicais podem ser um obstáculo para a criatividade dependendo de como forem tratados:

Toda a sua experiência é parte de quem você é. E nós armazenamos as nossas memórias, ou parecemos armazenar. Lembramos de coisas. Estas coisas surgem. Mas o processo do qual estou falando, que eu descrevi até agora, é diferente de ler música porque o sentido é do olho para o ouvido, ou poderia ser do olho para o corpo para o ouvido, ou nem mesmo ouvido, mas mente, para o córtex sonoro onde acontece a escuta. Não é o ouvido que escuta. O ouvido coleta informação sonora, então há um atraso. E tem mais atraso se você ficar pensando e analisando e criticando. Isso te afasta da escuta. O que eu tenho trabalhado é a espontaneidade, que significa que o corpo reage, e reage muito mais rápido do que você é capaz se você estiver pensando, ou lendo, ou fazendo qualquer forma de crítica, análise e assim por diante. Portanto, estou tentando conseguir uma resposta direta do meu corpo quando estou improvisando. Acho que também estamos buscando isso quando lemos música também, mas ler música nos dá a oportunidade de voltar e ler de novo. A improvisação não faz isso. Podemos dizer que é direto, a não ser que esteja trabalhando a partir da memória, trabalhando a partir do pensamento. O que você está pensando que vai fazer. Como por exemplo, talvez você tenha um monte de frases que você acumulou. E você toca estas frases quando tem a oportunidade. Isso não é espontâneo, embora possa ser feito com espontaneidade. Mas te deixa mais lento. ${ }^{65}$

O músico improvisador e psicólogo cognitivista Jeff Pressing, descreveu os lugares de onde partem musicistas de improvisação. Ou seja, estes passados todos que inevitavelmente compõe cada musicista. Pressing oferece um modelo baseado em dois conceitos fundamentais, a saber, referent e knowledge base. Com estas ideias das quais falarei mais a seguir, o autor buscou compreender os processos psicológicos envolvidos na improvisação. Seu trabalho trata principalmente de músicas baseadas em sistemas razoavelmente bem estabelecidos. Autores como Aaron Berkowitz fazem amplo uso de suas ideias dentro do ambiente da improvisação idiomática.

Em ampliação aos conceitos de Jeff Pressing, Costa oferece em seu livro, uma breve explicação de como Pressing originalmente os entende. Para Pressing referent é "um conjunto de estruturas cognitivas, perceptivas ou emocionais (restrições) que guiam e auxiliam na produção de material musical" (COSTA, 2016:190). Além disso, o referente é sempre relativo à performance em questão.

O outro conceito do par, isto é, knowledge base, é segundo Costa:

de âmbito mais amplo, inclui "materiais, fragmentos, repertório, habilidades, estratégias perceptivas, rotinas de resolução de problemas, estruturas e esquemas

65 Idem. 
hierárquicos de memória, programas motores generalizados" construído na "memória de longo prazo dos performers. (COSTA, 2016:191)

Nas páginas seguintes do livro, o autor oferece ampliações aos conceitos de Pressing que parecem mais adequadas à improvisação livre:

...numa definição mais abrangente, o referente pode ser entendido como qualquer estratégia específica local que é estabelecida pelos músicos durante ou no começo de uma performance. (COSTA, 2016:193)

Considerando que o referente é algo compartilhado por todos os performers e serve para guiar a performance em seu desdobramento temporal, na livre improvisação o passado da própria performance (envolvendo toda memória coletiva de curta ou longa duração) poderia ser considerada como o único referente para aquela performance específica. (COSTA, 2016:194)

Para a improvisação livre, é necessário ampliar esse conceito que deveria, então, envolver todo o background musical dos improvisadores. Nesse sentido, pode-se dizer, que para a improvisação livre, a base do conhecimento não é delimitada por uma (ou mais) linguagem musical específica, mas é constituída por todas as experiências sonoras e musicais dos improvisadores e por aquilo que está "antes" e "além" dessas linguagens, isto é, o "som puro", sua natureza, seus atributos e suas potências de futuro (suas virtualidades). Além disso essa redefinição da knowledge base teria de incluir também a ideia de know-how para lidar com o tempo (passado e presente), para interagir com os outros, e para ouvir o som como um material essencial e ilimitado para a prática musical (COSTA, 2016:195)

A respeito de como este repositório de materiais e habilidades, também descritos por Costa, é colocado em prática, Pauline Oliveros em seu artigo Improvised composition: how to listen in the time between apresenta algumas ideias que também se baseiam nas ciências cognitivas. Assim como outras improvisadoras que contribuíram para este estudo, a autora confia no corpo e suas imanências, e não em um processo de racionalização, para gerar a performance. A musicista conta no mesmo artigo:

Todas as minhas performances solo e em grupo são improvisadas. Quanto menos eu souber cognitivamente sobre a música que será improvisada, melhor para mim. Meu corpo-não-verbal faz a música valendo-se instantaneamente de toda a minha experiência. Eu confio na precisão do meu corpo nessa empreitada. Estou evitando pensar o meu caminho na improvisação. Estou confiando e contando com o meu corpo para manifestar a música de maneira pura e livre. (OLIVEROS, 2016:83) ${ }^{66}$

Algumas páginas depois, Oliveros fala sobre este processo de driblar os pensamentos associando-o à não-intencionalidade e, ao mesmo tempo, à intenção necessária para abrir-se para o momento:

O corpo, até agora de forma inexplicável, sabe compor e improvisar e solta esta informação por meio de palavras e gestos físicos, se estivermos abertos a receber a constante vigilância e output de atividade neuronal que não é conscientemente desejada. Paradoxalmente, é necessário desejo para estar aberto e confiar no corpo

66 Tradução minha. 
para entregar e integrar o que é necessário no momento da performance e ainda desconhecido para a mente verbal. (OLIVEROS, 2016:89) ${ }^{67}$

Ao falar sobre os conhecimentos deste corpo que improvisa, Pauline descreve dois tipos diferentes de atenção que estão envolvidas no devir improvisacional:

A atenção é frequentemente altamente focada para a linguagem, manifesta em palavras escritas ou faladas, matemática, música escrita, e programação. Este tipo de atenção focada pode separar-se da atenção aberta ou global. A atenção global pode perceber todas as sensações em todas as direções, tanto dentro quanto fora. A integração acontece quando há uma fusão dos dois tipos de atenção. Equilibrar estas duas formas de atenção é a dança da improvisação. Abrir para receber e focar em um ponto. A atenção focada deve proceder de ponto a ponto para manter a continuidade, mas a atenção global está sempre se expandindo e recebendo, embora desfocada nos detalhes. (OLIVEROS, 2016:87) ${ }^{68}$

\footnotetext{
${ }^{67}$ Idem.

${ }^{68}$ Idem.
} 


\section{Fim das entrevistas}

Para encerrar esta seção falta falar um pouco mais especificamente das entrevistas. Inicialmente eram dois músicos que seriam entrevistados. Os dois concordaram antes da pesquisa, no entanto, no momento de agendar as entrevistas não consegui obter resposta. Durante a primeira reunião de orientação acadêmica, decidi, junto com o Rogério, entrevistar um número maior de improvisadores. Elaborei uma lista com perto de vinte nomes. Mandei nove pedidos de entrevista por Skype, pensando que teria pelo menos três respostas positivas. Não sabia ao certo como seriam essas entrevistas ou o que faria com elas, por isso achei prudente não mandar mais. "Vai que todo mundo aceita." Como a lista era bem maior, e convidar não ofende, mandei pedidos para nomes bastante conhecidos, certo de que teriam muito a contribuir com a pesquisa, e imaginado que no máximo não responderiam ou diriam que não. De fato, consegui quatro entrevistas, sendo uma com o próprio Rogério. Na minha ousadia, pensei, "uai, vou chamar até a Pauline Oliveros. Já to chamando outros figurões." A maioria dos figurões nunca respondeu, e um negou, após algum tempo, por meio de uma assistente.

A primeira resposta que eu recebi foi de Susan Alcorn. No mesmo dia do convite, Alcorn respondeu confirmando interesse, explicando que estaria envolvida 
com outros compromissos nas semanas seguintes, e sugerindo datas para o encontro virtual. Alguns dias depois veio a segunda resposta. "A Pauline topou!” E pediu que fosse dois dias depois. Estava no começo da pesquisa. Um misto de felicidade e apreensão negociava um sentido de responsabilidade.

Deparei-me com a seriedade e a audácia do que havia me proposto. "Eu estou entrando no mestrado agora, tenho, de vida, metade do tempo de carreira dela..." A Pauline, embora menos conhecida do que alguns de seus contemporâneos, é uma dessas pessoas que mudaram maneiras de pensar, sentir e fazer arte. Que transformaram seus campos e as relações ao redor. Praticava improvisação, junto com Terry Riley e Loren Rush (OLIVEROS, 2016:76), dez anos antes dos pioneiros ingleses do $\mathrm{AMM}^{69}$, trabalhou com John Cage e o grupo Fluxus, foi uma importante compositora de música eletroacústica, inventou um modo de escuta e criou um instituto que dirigia, aos oitenta e três anos, onde recebia pessoas do mundo inteiro para praticar!

Pauline Oliveros, que eu estava quase certo de que estaria ocupada demais com suas responsabilidades de compositora, improvisadora, professora universitária e diretora do Deep Listening Institute, agradeceu o convite e sugeriu uma data. Não queria pedir para adiar e correr o risco de perder mais este relato. Meu desassossego é perceptível durante toda a entrevista. Entretanto, enquanto eu percorria, inquieto, o pdf com as perguntas e os benditos trechos de citação, Pauline gentilmente compartilhava sua experiência e oferecia um cuidadoso olhar para cada pergunta que eu havia preparado. Como já disse neste trabalho, os assuntos desta entrevista foram da prática do caratê à ameaça de Donald Trump.

Em suas palavras finais da entrevista, a musicista me desejou boa sorte com minhas improvisações, sugeriu não pensar muito, riu gentilmente e disse que aquilo era um começo.

Cinco meses depois, li a notícia triste de seu falecimento. E enquanto eu pensava sobre as nossas diferentes, e frequentemente conflituosas, relações com a impermanência, lembrava destes trinta e um minutos de entrevista que tiveram enorme importância para esta pesquisa e para minha prática musical. Espero que a maneira como

\footnotetext{
${ }^{69}$ Grupo de improvisação formado na metade da década de 1960 por onde passou músicos como Cornelius Cardew, Keith Rowe, John Tilbury, Eddie Prévost e Evan Parker.
} 
coloquei suas ideias neste trabalho possam contribuir para a continuidade do projeto de construção de novas subjetividades da musicista.

Susan Alcorn, a segunda entrevistada explicou em sua resposta ao meu pedido, que estaria indisponível naquele momento e sugeriu datas posteriores. Eu prontamente concordei com uma das datas e enviei as "instruções" (agora tenho dificuldades para pensar em uma palavra pior do que essa) para a entrevista. Em pouco tempo, Alcorn respondeu explicando que escrevia de seu telefone enquanto viajava a trabalho, mas que estava animada para ler as instruções e perguntou sobre a situação política do Brasil, como mostra o trecho do e-mail que segue:

Tenho tentado seguir as notícias do golpe no Brasil (a grande mídia aqui é totalmente tendenciosa) e estou horrorizada com o que aconteceu. Eu sei que houve corrupção (em toda parte, como nos EUA), mas o governo novo parece um completo pesadelo - criacionistas, negadores das mudanças climáticas, e corporações multinacionais tentando destruir a cultura de uma nação, e eu estremeço de pensar nos efeitos sobre a Floresta Amazônica. ${ }^{70}$

A entrevista foi a mais longa das quatro. As citações do modelo de entrevista, mais uma vez, não foram utilizadas, mas as perguntas foram quase todas respondidas. A guitarrista me perguntou se o lugar onde eu morava era perto de São Paulo, por onde ela já havia passado. Comentou sobre o tamanho do Brasil e conversou sobre viagens longas de trabalho. Disse que não sabia se conseguiria ajudar muito e que poderia apenas contar suas experiências e suas ideias. Suas contribuições contaminaram de maneira determinante, tanto minha prática como improvisador, e minha relação com as técnicas estendidas, quanto diversos outros aspectos desta pesquisa. Ao fim da entrevista, desejou-me sorte com o mestrado, e "todas as coisas boas na música e na vida".

Chefa Alonso, que já havia estado no Brasil em outras ocasiões, gentilmente cedeu o seu horário de almoço do ateliê que conduzia na VI Semana de Educação Musical realizada no Instituto de Artes da UNESP. Combinamos de nos encontrarmos na cantina no instituto. A entrevista aconteceu em uma mesa no canto onde eu esperava junto com Miguel Antar, que contribuiu com perguntas, comentários, e ajudou com traduções quando necessário. Também estava presente Yonara Dantas, que apenas assistiu.

\footnotetext{
${ }^{70}$ ALCORN, 2016. In: comunicação por e-mail que precedeu a entrevista. Tradução minha.
} 
Apesar das semelhanças entre os idiomas e meu nível intermediário de espanhol, acreditei que a entrevista seria melhor se houvesse um entrevistador que falasse a mesma primeira língua da entrevistada. As contribuições de Miguel trouxeram um olhar atento para a fala de Alonso e as relações que o pesquisador e improvisador estabelece durante a entrevista e nos comentários que acompanham a transcrição em anexo revelam aspectos da preparação para a improvisação livre que de outra forma provavelmente não surgiriam. Antar também tirou dúvidas de tradução durante a entrevista e depois na transcrição.

Em poucos minutos Chefa chegou. Andando rápido, veio até a mesa e nos cumprimentou, um a um, com um abraço e um beijo. Conversou um pouco sobre seu período no Brasil e me pediu para falar sobre a minha pesquisa e sobre a Orquestra Errante. Depois disso fomos às perguntas divididas em tópicos, a esta altura já sem as citações. Perguntada se havia alguma outra coisa que achava importante e que gostaria de falar, Alonso destaca a importância da continuidade destas práticas de subjetivação. Como mostra a citação seguinte, suas respostas demonstram claramente processos de subjetivação centrados na relação com o outro e focados em manter-se neste movimento a despeito das contingências. Termino esta seção com as últimas palavras da improvisadora antes de despedir-se, que remetem à descrição feita pelos filósofos estudados por Foucault das estruturas de manutenção da ascese. Chefa Alonso:

Creio que é importante e tento sempre dar confiança para as pessoas que às vezes estão inseguras porque é um caminho muito inseguro e muito incerto. Porém, agora é menos inseguro, porque há mais improvisadores, há uma cena de improvisação em muitos lugares. Mas quando eu comecei no meu país, na Espanha, não havia absolutamente nada, nesse tempo eu não sabia se eu era esquisita porque eu tocava esquisito [...], contudo, eu creio que é importante que as pessoas confiem em si mesmas, no que pede o corpo, no que pede a cabeça. Isso sempre é verdade. Ainda que o mundo esteja contra isso e sejas criticado. Se você tem alguma tendência a fazer algum tipo de música, - música pode ser até um tipo de dança, algum tipo de arte -, por mais que ache estranho, por mais que pareça esquisito, corre em direção disso, porque isso é que é verdade. Neste sentido animal. Há pessoas que pensam que é difícil, que é um caminho muito longo, mas eu creio que a liberdade é para o que estamos aqui. A liberdade é fundamental. Então devemos animar o pessoal a que não tenha medo. Que vá! ${ }^{71}$

${ }^{71}$ ALONSO, 2016. Tradução minha. Revisão de Miguel Antar. 


\section{SEÇÃO III}

CUIDADOS DE SI, FEMINISMOS E IMPROVISAÇÃO LIVRE 
Este trabalho está repleto de processos improvisatórios. Desde o tema principal da pesquisa de mestrado do qual faz parte - Relatos e reflexões sobre processos de subjetivação e preparação para improvisação musical livre - até a necessária mudança no olhar do pesquisador para acolher o inesperado. A partir dele se desenharam novas questões, de onde brotaram novos caminhos. Esta seção é um destes. Já era imaginado, antes do início da pesquisa, que os relatos que eu pretendia colher me levariam por trilhas que só seriam conhecidas no próprio processo da pesquisa. Caso contrário, não valeira a pena pesquisar.

O meu interesse com os pedidos de entrevista era poder conversar sobre uma parte do trabalho de cada um, à qual, em geral, pouco se tem acesso. Maneiras como musicistas descrevem e refletem sobre as práticas que acreditam compor sua preparação para improvisar. Elaborei meu projeto ciente de que as respostas seriam diversas, como foram, e possivelmente envolveriam atividades das mais variadas. De caratê ao estudo de escalas, de andar de bicicleta a improvisar com gravações de outros improvisadores. Neste sentido, havia uma abertura intencional na elaboração das questões. Queria deixar espaço para indeterminação. 
"Preparação" é uma palavra quase vaga demais, portanto é necessário cuidado em sua explicação. Não gostaria de guiar mais do que o inevitável a maneira como esta palavra tão ampla era compreendida pelos entrevistados. O plano quase infalível de não esperar nada especificamente, rapidamente mostrou-se frágil. Como frequentemente acontece com as nossas expectativas em improvisações livres, fui surpreendido. Uma aparente coincidência se colocava cada vez mais no centro da pesquisa e mostrava que os dados que eu colhia não deveriam vir somente das respostas pronunciadas durante as entrevistas, mas de onde e como vinham estas respostas. Estas entrevistas são mais cuidadosamente tratadas na seção relatos e processos.

No decorrer da presente seção falarei sobre esta que talvez seja a principal surpresa deste trabalho. Com exceção do meu orientador, só obtive resposta positiva das mulheres a quem solicitei entrevistas. Não era mesmo esperado que todos os pedidos de entrevistas fossem aceitos. Solicitei o tempo e atenção de pessoas muito ocupadas e já imaginava que a maior parte não concederia. Por isso mandei um número de convites que previa a possibilidade da maioria não aceitar, como de fato aconteceu. No entanto, o padrão que se estabeleceu parece dar indícios de dados relevantes para a pesquisa.

A amostragem pequena de pedidos enviados, ao todo nove, é mais um motivo pelo qual este trabalho não tem nenhum interesse em estabelecer verdades ou sugerir normas que relacionem gênero e improvisação livre. Intento somente observar como aparentes coincidências no processo de pesquisa afetaram o olhar do pesquisador, e apontar as reflexões que daí brotaram. A maneira como os fatos se distanciaram do plano inicial gerou uma situação que eu não poderia ignorar. A incursão nos estudos feministas e de gênero, embora não seja o foco principal da minha pesquisa, mostrou-se necessária para entender por que o assunto que escolhi parecia interessar mais às mulheres a quem pedi entrevistas, do que aos homens.

A aparente coincidência ganhou nova luz no X Colóquio Internacional Michel Foucault - É inútil revoltar-se? Foucault e as insurreições ${ }^{72}$. Neste evento promovido pelo Instituto de Filosofia e Ciências Humanas e pela Faculdade de Educação da Universidade Estadual de Campinas, deparei-me pela primeira vez com a necessidade

\footnotetext{
${ }^{72}$ https://www.ifch.unicamp.br/ifch/noticias-eventos/programa-historia/x-coloquio-internacional-michelfoucault-inutil-revoltar-se
} 
de aproximar-me dos estudos feministas. As falas de duas mulheres - Margareth Rago e Margaret McLaren - atentaram-me para algo que parecia juntar peças importantes que flutuavam desconexas pela minha pesquisa e passavam-se por felizes coincidências. A relação das mulheres com o cuidado de si.

Para Michel Foucault por meio do cuidado de si, se dá a construção do próprio sujeito. Foucault realiza uma reflexão acerca deste conceito principalmente em filósofos clássicos gregos e romanos, além de uma genealogia desta forma de cuidado, a partir de sua referência, mostrando as transformações que este sofre na história.

Esta forma de organizar práticas na busca da virtude e da construção do sujeito, mostra o filósofo, busca "não só uma atitude geral para consigo, mas para com os outros, com o mundo" (Foucault, 2014:11). As duas autoras com quem tive contato durante o colóquio Foucault possuem extenso trabalho a respeito de feminismos, Foucault e subjetividade.

Entre os trabalhos encontrados na literatura musical que se interessam pela relação entre práticas de subjetivação e processos criativos, destacam-se artistas como Pauline Oliveros, Cornelius Cardew e Chefa Alonso. As três obras envolvem práticas e reflexões sobre o ato de improvisar e fatores que o cercam que, acredito, encontram espaço sob o guarda-chuva foucaultiano do cuidado de si. Adiante falarei mais sobre estas referências. Formas de cuidados de si também podem ser encontradas muito antes na história e certamente ultrapassam o momento observado por Foucault. Esta ideia não está, portanto, restrita à filosofia grega ou a Foucault, ou aos feminismos que daí se inspiram e artistas que se valem desta ou daquela prática. A pesquisa que elaborei era sobre a relação de músicos improvisadores com o cuidado de si e de repente, além do meu orientador, eu só havia conseguido relatos de improvisadoras.

Por que o assunto que eu escolhi parecia mais caro às mulheres do que aos homens? Foram ao todo, nove pedidos de entrevistas, como disse. Seis para homens e três para mulheres. Entrevistei Pauline Oliveros, Chefa Alonso e Susan Alcorn. E entre os homens, Rogério Costa. Com isso, parti de uma desproporção inicial de dois homens para cada mulher e cheguei a uma de três mulheres para cada homem. E ainda achava que era coincidência. Durante o colóquio de Foucault que mencionei, diversas falas que citavam Margareth Rago, e ela própria, discutiam a proximidade histórica entre as 
mulheres e o cuidado de si. No mesmo dia, Margareth McLaren falou sobre Foucault, feminismos e subjetivação. Nesta tríade bastava substituir feminismos por improvisação livre que as ideias continuavam funcionando. Caia uma ficha. Ficou claro que minha relação com o feminismo precisava ser revista e que este tema, de alguma forma, deveria fazer parte da minha pesquisa.

Sempre fui favorável às lutas feministas devido a uma repulsa por toda forma de dominação de um ser humano por outro. Isto me dava certeza de que todos os movimentos feministas — que embora existam há bastante tempo, têm obtido alcance inédito - são importantíssimos para toda a sociedade. Sabia também da necessidade de procurar desconstruir atitudes, pensamentos e comportamentos que reproduzem uma lógica de opressão às mulheres. Contudo, as leituras do mestrado, os estudos, os ensaios, as aulas, os trabalhos, os cuidados com a casa, a família... a enorme lista de afazeres parecia empurrar autoras feministas para o final da fila. Confesso que meu repertório de estudos feministas, até recentemente, se restringia à alguma coisa da Emma Goldman que li há muito tempo, e uma entrevista com a Judith Butler, lida mais recentemente.

Concluí, então, que faria pouco sentido realizar uma pesquisa em improvisação livre, que não fosse capaz de acolher contingências tão fortes como esta e refletir constantemente sobre os rumos que se apresentam sem aviso. Percebi que precisava saber mais sobre aquilo, ainda que não tenha sido capaz de reconhecer este dado a tempo para as entrevistas e, infelizmente, em um dos casos nunca poderei perguntar. O quanto conseguirei me informar durante esta pesquisa de mestrado é também limitado, mas abre caminho para um processo de reflexão e aprendizado em relação a estas questões de pertinência extrema para a improvisação e para toda a vida.

Minha aproximação da obra de Foucault veio por uma aparente semelhança entre práticas diárias de musicistas improvisadores, e de filósofos helenísticos e romanos que o autor descreve em sua Hermenêutica do Sujeito. Fui parar em Foucault por influência de pesquisas no campo das artes performativas a respeito da preparação do ator. A importância das práticas de subjetivação nas obras de Stanislavski, Brecht, Grotowski, Artaud e outros nomes de peso deste campo é bem mais clara do que na música. Autores contemporâneos brasileiros como Quilici e Ferracini referem-se à Hermenêutica de Foucault para desenvolverem suas reflexões sobre a preparação do ator, atriz, performer. 
A descrição que o filósofo faz destes processos e principalmente destas maneiras de conduzir a vida alimentam o pensamento sobre diferentes aspectos e práticas de vidas dedicadas a um objetivo ético e estético. Os estudos a respeito destes processos de subjetivação na filosofia grega e romana não eram referência significativa para nenhuma das improvisadoras entrevistadas. Contudo, a despeito das três esclarecerem que não poderiam ajudar muito em relação a esta bibliografia tão específica, todas concederam longas e generosas entrevistas sobre seus processos de preparação. Perguntas sobre escuta, atenção, técnica instrumental e outras habilidades relacionadas à preparação para a improvisação livre foram respondidas com atenção e interesse. 


\section{As virtudes associadas à música}

Uma expressão bastante clara de formas de cuidado de si encontradas na literatura sobre música improvisada também pode ser vista no trabalho do músico inglês Cornelius Cardew. Embora este não use propriamente o conceito de Foucault. Cardew integrou o $A M M$, grupo londrino precursor da improvisação livre e foi fundador da Scratch Orchestra. Chefa Alonso recorre em seu livro Improvisación Libre, às virtudes associadas à música enumeradas pelo autor e improvisador, originalmente publicadas no texto intitulado Towards an ethic of improvisation. Qualidades e valores que possuem eco em diversas formas de subjetivação como no zen budismo e na filosofia clássica. As sete virtudes, segundo Cardew, são: simplicidade; integridade, auto-desinteresse, paciência e domínio de si, prontidão, identificação com a natureza, aceitação da morte. $\mathrm{O}$ principal interesse desta investigação é refletir a cerca dos processos, caminhos e práticas que musicistas adotam em função de necessidades de desenvolver-se nestas e em outras virtudes que acreditem possuir relação com a improvisação musical. É digno de nota que, embora não dê maiores explicações, Cardew, no texto mencionado, diferencia-se do que chama de "músicos profissionais" que, segundo ele, fariam o som, ao passo que o tipo de músico para os quais se referem estas virtudes seriam o som. 
Pauline Oliveros

Durante a entrevista com Pauline Oliveros, questões como o racismo e a discriminação mostraram-se determinantes em um desejo de criar algo que se oponha diretamente a isto, além da associação deste esforço à sua prática de improvisadora. As ligações da compositora e improvisadora com movimentos feministas da segunda metade do século XX são investigadas no trabalho de Martha Mockus intitulado Sounding Out: Pauline Oliveros and Lesbian Musicality. Neste estudo aprofundado sobre a vida e obra da improvisadora, Mockus ressalta o que Oliveros revela em seu livro Deep Listening: A Composer's Sound Practice, que as Sonic Meditations, parte tão importante de sua obra, foram elaboradas com um grupo só de mulheres, na Universidade da Califórnia em San Diego nos Estados Unidos.

Outro trabalho importante para compreender não só esta compositora e improvisadora, mas a participação de outras mulheres na música improvisada, pode ser encontrado no artigo de Oliveros intitulado Harmonic anatomy: Women in improvisation. Neste texto curto, a autora oferece um relato de sua formação musical que tem início na infância com ajuda de sua mãe e sua avó, ambas pianistas. A autora conta também como 
passou por alguns episódios lamentáveis de opressão e humilhação pública em sua formação como musicista.

A trajetória descrita mostra, a despeito das dificuldades, um impacto claro da autora nos ambientes musicais à sua volta além da criação de novos ambientes para a prática de improvisação entre mulheres. A continuidade dos trabalhos do Deep Listening Institute, e o evento Improvisation and Listening - Conference in Memory of Pauline Oliveros, realizado em 2017 pelo International institute for critical studies in Improvisation, na McGill University, em Montreal, indicam a relevância da obra de Oliveros para o pensamento e a prática musical atual.

Para descrever o cenário do qual parte uma mulher que se aventura a improvisar música, e os desafios de gênero que encontrará, a autora faz uso de trechos curtos de crítica musical nos quais há uma diferença clara nos valores e nas qualidades associadas aos gêneros revelada na linguagem utilizada para descrever improvisadores e improvisadoras. "Fluência técnica", "inteligência" e "precisão" são raramente citadas nas críticas às mulheres. Da mesma forma, não se vê referência ao "toque doce dos lábios" de nenhum improvisador. Dificilmente encontramos a performance de um homem descrita como "íntima e sensual", ou referência à "precisão intensa" de uma mulher.

Outro valor comumente associado ao homem é a competitividade. Menos citada nas críticas, mas não menos presentes em ambientes musicais. Poder sentirse ouvida e sentir-se em colaboração foi o que levou Oliveros a formar seus diferentes grupos de mulheres improvisadoras, segundo relata no artigo citado. Nestes grupos, a autora conta, não se sentia como um concorrente intruso.

A menor presença feminina apontada por Oliveros parece seguir como regra na maior parte dos países e na maioria das práticas musicais, inclusive na improvisação livre. De fato, em minha trajetória até hoje como músico, nunca estive em um ensaio com mais mulheres do que homens. A imensa maioria dos ensaios em que estive nos últimos vinte anos era exclusivamente de homens. Chama atenção quando o número de mulheres e homens em um grupo é igual, ou quase. Não é eufemismo, como homem que sou, dizer que é impossível imaginar as dificuldades e as frustrações que deve enfrentar qualquer mulher que decida fazer música, improvisada ou não. 
A competitividade do homem bem-sucedido, tão valorizada no mundo dos negócios, e de forma um pouco velada em certos círculos musicais, possui muitas vezes uma capacidade de violência simbólica esmagadora de qualquer criatividade. Assim, a violência simbólica machista que tão frequentemente acompanha esta forma de existir, também não raro, velada, manifesta-se de maneira sutil e eficiente para criar condições que dificultam imensamente o acesso de qualquer mulher à música salvo como espectadora. Oliveros relata sua experiência em um tempo em que era bem menor a participação de mulheres na música improvisada:

No fim dos anos sessenta, minha experiência com improvisação era quase que exclusivamente solo ou com grupos de homens. Minha posição era única. Eu era bem-sucedida entre músicos homens, mas às vezes sentia desconforto. Mesmo tendo sido incluída nos grupos nos quais trabalhava, eu sentia uma barreira invisível. (OLIVEROS, 2004:54) ${ }^{73}$

Apesar da realidade desfavorável que encontram as improvisadoras, o trabalho de pessoas como Pauline Oliveros certamente contribui para que hoje circule por territórios da improvisação livre uma ética de igualdade. Além da necessidade de expressão individual de mulheres que nem sempre encontram este espaço em grupos de homens, as relações de cuidados ficam evidentes nas descrições que a improvisadora e compositora faz de seus grupos. Oliveros também oferece uma lista de improvisadoras com quem trabalhou, entre elas Susan Alcorn também entrevistada nesta pesquisa. Cada uma delas é atenciosa e respeitosamente descrita em relação às suas ideias e suas práticas musicais. Fato relevante sobre a lista de improvisadoras oferecida por Oliveros é que não são nomes facilmente encontrados nas referências mais comuns à improvisação.

Outro grupo de considerável importância histórica para a improvisação livre foi o Feminist Improvising Group (FIG). Este coletivo de improvisadoras reuniu mulheres que hoje ocupam posições de destaque na música experimental como Georgina Born, Irène Schweizer e Magie Nichols. No entanto, as referências encontradas online são bastante limitadas em relação a grupos masculinos como o $A M M$ integrado por figuras como Cornelius Cardew, Keith Rowe e Eddie Prévost. A escassez de comentários sobre práticas de cuidado de si e novos modos de subjetivação na preparação para a improvisação poderia estar associada a uma maior circulação de um discurso tido como masculino?

73 Tradução minha. 
Ao observar o fato importantíssimo de que a maior parte das vagas em grupos musicais de qualquer gênero ainda é ocupada por homens, a autora reforça o que já sabemos. Estamos ainda muito longe de uma forma de viver mais igualitária. Os grupos musicais, inclusive na improvisação livre, ainda são majoritariamente formados por homens e a atenção dada aos grupos de mulheres é frequentemente tendenciosa. As mulheres ainda sofrem diferentes violências dentro de grupos musicais regidos por uma lógica masculina. As lutas feministas, dentro e fora da improvisação livre estão longe de acabar.

Começamos este ano de 2017 com a notícia de um massacre feminicida na cidade onde nasci e moro ${ }^{74}$. Próximo à antiga casa de um amigo. Em terras mais distantes, o governo Russo aprovou em última instância texto que despenaliza a violência doméstica que não cause o que definem como danos permanentes à saúde ${ }^{75}$. Como um requinte de crueldade, esta iniciativa partiu de duas deputadas e duas senadoras russas. Não cabe a ilusão de que logo as coisas vão ficar bem. No entanto, trabalhos como o de Pauline Oliveros oferecem ferramentas práticas para buscar a multiplicação de ideias que visam um mundo menos misógino. O horror que estas monstruosidades ainda causam não deve nos impedir de perceber transformações notáveis na sensibilidade de mulheres e homens. Violências que há vinte anos passavam em branco, hoje recebem atenção inédita e forçam homens e mulheres a refletir sobre relações de gênero.

\footnotetext{
74 https://brasil.elpais.com/brasil/2017/01/02/politica/1483367977_559818.html

${ }^{75}$ https://www.theguardian.com/world/2017/feb/07/putin-approves-change-to-law-decriminalisingdomestic-violence
} 


\section{Chefa Alonso}

Chefa Alonso, de quem já falamos algumas vezes neste texto, é autora de um trabalho bastante rico que vê na improvisação livre possibilidades reais de transformação do sujeito e do mundo, além de oferecer ferramentas pedagógicas claras para este desenvolvimento. Talvez por outra dessas "coincidências", é espanhola como as Mujeres Libres descritas por Rago em artigo sobre a experiência desta organização anarco-feminista $^{76}$. Este grupo de mulheres foi formado poucos meses antes do início da guerra civil que levaria à longa ditadura de Franco e, como mostra a historiadora, teve importante atuação em conquistas como a criação de espaços de acolhimento para mulheres, a legalização do aborto e a criação de novos modos de subjetivação em um país altamente conservador. Estas conquistas são resultado de lutas, muitas vezes até a morte, e criaram condições sociais que não podem ser compreendidas como naturais. Estas condições são o lugar e tempo onde nasceu a musicista de quem falarei agora.

As conquistas desta luta anarco-feminista que antecedeu e ofereceu resistência ao regime de Franco, deixaram vestígios que ajudaram a compor o contexto

\footnotetext{
${ }^{76}$ RAGO, 2008.
} 
no qual Alonso ganha tamanha relevância tanto para a performance de música livremente improvisada quanto para pesquisas neste campo. Seria também coincidência seu trabalho pedagógico e seu cuidado com a maneira como as habilidades são desenvolvidas dentro do grupo, além da ética não hierarquizada que acompanha seus ateliês de improvisação?

A maneira como a autora fala sobre a improvisação livre descreve uma forma de ver e entender música indissociável de questões éticas. Chefa diz "eu creio que a regra básica da improvisação livre é a democracia e o respeito pelo outro."77 Podemos ouvir ecos das Mujeres Libres quando ao refletir sobre as incertezas dos caminhos que escolheu, Alonso conta: "Há pessoas que pensam que é difícil, que é um caminho muito longo, mas eu creio que a liberdade é o porquê de estarmos aqui. A liberdade é fundamental." ${ }^{~ 78}$ A postura da improvisadora em relação às dificuldades encontradas no mundo fora da improvisação é bastante clara no sentido de ver nesta maneira de se fazer música, a possibilidade de estar no momento presente entre um coletivo que busca atualizar esteticamente ideias de interação não-hierárquica. Este lugar onde se pode experimentar condições não hegemônica de criação e execução musical como um laboratório para o mundo e não uma negação deste, aproxima-se da noção foucaultiana de heterotopia.

Em seu texto de 1967 intitulado De Outros Espaços, Foucault apresenta a ideia de heterotopia, que apresento aqui, grosso modo, como uma atualização localizada de um outro espaço com condições únicas e não-hegemônicas. Como museus, zoológicos, bordéis, prisões, etc. De situações que permitem vislumbrar algo que só existe naquele contexto, como artefatos de outros tempos, animais de outros lugares, comportamentos sexuais socialmente condenáveis, sujeitos considerados perigosos para a vida em coletivo... A heterotopia é este outro lugar inventado. Com outras regras e outras formas de existir.

Na citação que segue Chefa Alonso faz referência à improvisação livre como um ambiente no qual é possível vivenciar relações diferentes das oferecidas pelas hierarquias musicais tradicionais. Para Alonso:

Um dos elementos mais bonitos da improvisação livre é a sensação de pertencer a um coletivo que pode ser universal, um coletivo no qual a igualdade é uma de suas qualidades mais relevantes. Embora seja verdade que em uma orquestra convencional

\footnotetext{
77 ALONSO, 2016. Tradução minha. Revisão de Miguel Antar.

78 idem.
} 
podem coincidir músicos de diferentes lugares, o que fazem em comum é tocar a mesma partitura. Na improvisação livre a partitura é a própria linguagem e o passado de cada um em diálogo ao vivo com os demais. Em grupos de improvisadores a hierarquia própria das orquestras felizmente desapareceu. Há músicos com mais e com menos experiência, mas isto não torna ninguém primeiro ou segundo violino. $\mathrm{O}$ discurso de cada um possui igual importância. (ALONSO, 2008:101) (99 $^{79}$

Para que seja possível este ambiente, é necessário que se esteja ativamente envolvido no desenvolvimento de habilidades para relações não hierárquicas. São necessárias ferramentas que nem sempre são encontradas em processos pedagógicos musicais mais tradicionais. O que seria necessário fomentar para formar este sujeito de preocupações éticas e estéticas? Que relações de mundo são ensinadas nos cursos tradicionais de música? O que está implícito na escolha pela notação visual como forma maior de transmissão do conhecimento musical? Chefa Alonso oferece em seu livro Improvisación Libre pistas que podem nos ajudar com estas questões. Segundo a autora, o início da história da notação musical coincide com um desejo de codificar e estabelecer normas universais por parte da igreja medieval. Alonso cita o compositor norteamericano John Cage que acreditava que "os tipos de música menos anárquicos exemplificam estados da sociedade menos anárquicos. As grandes obras da música ocidental dão exemplo das monarquias e das ditaduras." (CAGE. In: ALONSO, 2008:30. $)^{80}$

Quais seriam, portanto, as ferramentas propostas pela musicista espanhola para criar este ambiente conducente à improvisação e a outras formas de interação no mundo? No seu livro de 2014 Enseñanza y Aprendizaje de la Improvisación Libre, a autora reúne ideias de diferentes artigos sobre este tema. São também sugeridas atividades práticas de improvisação que buscam desenvolver habilidades específicas como escuta, alteridade, adaptação, negociação, confiança, autonomia e diversas outras. Além das instruções escritas que acompanham cada exercício, Alonso propõe exercícios de interação musical a partir de diversos estímulos como imagens e poemas.

Para a autora "a improvisação põe em jogo de forma poética, modos de relacionar-se com o mundo e com os demais" (ALONSO, 2008:51). Um dos textos encontrados nesta obra de Alonso é escrito pelo pesquisador e educador Alejandro RojasMarcos. Segundo Marcos:

\footnotetext{
${ }^{79}$ Tradução minha.

${ }^{80}$ Idem.
} 
No contexto de uma classe de improvisação, é interessante observar como nas primeiras seções as peças terminam invariavelmente entre risos dos alunos. Para eles é uma experiência libertadora e surpreendente. Escutam o resultado e comprovam que, ao contrário de suas expectativas, são capazes de criar sentido musical coletivamente de maneira espontânea sem ajuda de partitura e além disso, isto é aceito e valorizado. Aí começa um caminho no qual é necessário que os alunos desenvolvam a confiança em sua própria intuição, em seu próprio impulso... (MARCOS In: ALONSO, 2008:69) ${ }^{81}$

Além do desenvolvimento da confiança e da autonomia, que é bastante facilitado por um ambiente majoritariamente livre de ameaças simbólicas, Chefa Alonso observa outras qualidades que musicistas de improvisação devem possuir como escutar, dar espaço aos demais e seguir sempre curiosa e buscando. A improvisação livre não é um universo paralelo que resolveu as questões do mundo e oferece asilo aos que quiserem uma vida de paz. Este território musical é definido por um constante caminhar que não alivia nenhum de seus praticantes. Chefa Alonso afirma que "o objetivo sempre está mais adiante" (ALONSO, 2008:71.) $)^{82}$

Falarei, a seguir sobre o que a autora feminista Margareth Rago chama de feminização do mundo. Acredito que a produção das musicistas de quem falei até o momento parece justificar a observação de Rago de que o mundo tem se transformado e se tornado mais feminino.

O que é de fato feminino, e o que é histórica e culturalmente construído, e como estas denominações se relacionam com clichês de gênero, são certamente discussões importantes demais para serem feitas de maneira superficial. Da minha parte, necessitaria de uma intimidade muito maior com este campo de estudo. Compreendo, portanto, o termo usado por Rago como referência a traços de cuidado frequentemente associados a mulheres, e divergentes de uma lógica belicista e competitiva, por sua vez associada a homens.

A historiadora observa que os efeitos desta transformação não são visíveis apenas nas mulheres. A partir do momento que estes discursos ganham maior circulação, homens e mulheres são afetados. Novas formas de sensibilidade, não pautadas na dominação e na normatividade, tomam corpo, emergem e se espalham a partir deste contexto.

\footnotetext{
${ }^{81}$ Idem.

${ }^{82}$ Idem.
} 


\section{Cuidados de si e feminismos}

Antes mesmo de definir quem eu entrevistaria, elaborei o meu projeto de mestrado por acreditar que poderia compreender processos de preparação para a improvisação livre com ajuda do trabalho de Michel Foucault sobre as práticas da antiguidade clássica. Diversas ideias apresentadas pelo filósofo pareciam ecoar no que conhecia da literatura sobre improvisação e na minha própria experiência musical. Tanto a obra de Foucault quanto as propostas éticas apresentadas pelas autoras deste estudo revelam buscas incessantes por um fim que caminha com a linha do horizonte, mas não só. Estes trabalhos oferecem possibilidades práticas que permitem materializar este horizonte como algo mais do que uma miragem. Ainda que em espaços e tempos restritos, estes processos existem dentro de um contexto de práticas que visam gerar novos modos de subjetivação.

Descobri no processo da pesquisa, que a relação das mulheres com o cuidado de si é muito mais documentada do que a da improvisação livre. O feminismo, para Rago, encontra-se em um momento bastante significativo. A autora aponta que embora a luta esteja muito longe de acabar, podemos observar conquistas do movimento dentro da sociedade, "produzindo importantes efeitos na sensibilidade e no imaginário 
social, claramente perceptíveis na vida cotidiana." (RAGO, 2004:6). Haveria algo associado à maneira que eu propunha tratar da improvisação livre, que traria de alguma forma traços do que Rago define como uma feminização? Ainda sobre este processo, Rago indica que estas mudanças acontecem:

...especialmente a partir da constituição de um novo olhar sobre si e sobre o outro e, nesse sentido, penso num processo de feminização cultural em curso - o mundo tem se tornado mais feminino e feminista, libertário e solidário ou, em outras palavras, filógino, (RAGO, 2004:3)

A historiadora brasileira, referência em estudos feministas, também aponta diversos fatores que aproximam as mulheres do cuidado de si. A distância histórica das guerras e do policiamento, o cuidado com a família e o espaço, as reflexões e lutas feministas e suas conquistas, entre outros. A historiadora defende que "as mulheres, por terem sido excluídas do mundo masculino, desenvolveram modos próprios de ser, menos agressivos e mais voltados para a vida." (RAGO, 2004:6). Tudo isso contribui, segundo Rago, para a proximidade das mulheres com o cuidado. Todo o trabalho sobre si que compõe tanto as práticas de Deep Listening de Oliveros quanto os ateliês de improvisação de Alonso, também contempla sujeitos que se constroem ética e esteticamente na relação com os outros.

$\mathrm{Na}$ introdução à entrevista com Judith Butler, Tracy McMullen reflete sobre um processo de encontro com o outro e com o desconhecido que acontece de maneira improvisada na vida cotidiana. Para McMullen: “O sujeito é capaz de reconhecer sua incompletude, contingência, e surgindo com o outro, ela ou ele pode manter-se aberta para a natureza produtiva do discurso, permitindo que novos significados continuamente venham à tona. (MCMULLEN, 2016:22. $)^{83}$

Para Butler a "improvisação designa um domínio relativo de liberdade em um mundo determinado por regras.” (MCMULLEN, 2016:26) ${ }^{84}$. Ao transportar este pensamento especificamente para o universo da improvisação livre, podemos pensar esta liberdade relativa de diferentes formas. Rogério Costa vê na improvisação livre as ideias do filósofo Gilles Deleuze de um jogo cujas regras são feitas ao jogar. Um oásis temporário à normatividade onde são ensaiadas novas formas de existência. Estas regras em relação às quais agimos não deixam obviamente de existir no mundo enquanto

\footnotetext{
${ }^{83}$ Tradução minha.

${ }^{84}$ Idem.
} 
tocamos. Não há suspensão da realidade. Há o devir de outras realidades na coragem do salto para o desconhecido, na escuta atenta, na interação sem hierarquias, na busca por desfazer-se de automatismos.

Não defendo que inexistam relações de poder dentro de grupos de improvisação. Relações de poder estão presentes, aponta Foucault, em qualquer interação entre seres humanos. $\mathrm{O}$ autor sugere que elas são transitórias, instáveis e dependem de inúmeros fatores. O filósofo explica que quando este poder se concentra exclusivamente sobre uma das partes, tornando a outra subjugada, há dominação. Isto é algo que deve ser considerado até mesmo em grupos de improvisação livre nos quais uma figura exerce uma função pedagógica ou burocrática centralizadora. Acredito que deva fazer parte do esforço de quem ocupa este posto, buscar um ambiente não-hierarquizado no qual todos são ouvidos, tanto no sentido musical quando nas discussões. Este esforço é algo que percebi em todos os grupos de improvisação dos quais já participei e parece estar de acordo com as ideias de todas as entrevistadas.

Idealmente, as tarefas devem ser distribuídas de maneira a não sobrecarregar ninguém ou concentrar informação demais em uma pessoa. Trabalhos de produção como busca de recursos financeiros, busca de locais para apresentação e viabilização destas por meio do estabelecimento de contatos com gestores responsáveis, além da organização de material de mídia... são responsabilidades de todos os integrantes do grupo e podem ser realizados por qualquer um que quiser e puder. Sendo assim, há maior alternância nas pessoas que inevitavelmente tomam pequenas decisões que são, sem dúvida, determinantes no processo. Questões internas ao grupo como datas e horários de ensaio, administração de recursos, formato de ensaio, duração e caráter das músicas, desenvolvimento de propostas comprovisatórias, e redação de atas, são compartilhadas e as decisões são debatidas e tomadas por aqueles que se encontram presentes no momento do debate. Cuidados com o espaço e o equipamento também devem ser coletivos no ambiente da improvisação livre. Experiência musical, idade, gênero, etc. não devem ser fatores decisivos nas decisões do grupo.

Obviamente, eu não tenho a ilusão de que a improvisação livre esteja imune a ideias e atitudes hierárquicas, competitivas, machistas ou que de outras formas contrariam a ética que observo neste movimento musical. Os ambientes de improvisação 
que frequento continuam sendo majoritariamente ocupados por homens brancos como eu, de ao menos razoável condição social.

Estas heterotopias, nas quais são germinadas formas de convivência diferentes daquelas impostas pelo mundo, embora atualizem no espaço entre os corpos utopias de interação, são formadas entre seres que, na melhor das hipóteses, lutam por uma desconstrução de modelos de subjetividade que inevitavelmente deixam rastros em comportamentos que não condizem com a ética do espaço em questão.

A improvisação livre não é, ou pretende ser, um território que busca a perfeição. É um lugar no qual o erro pode ser trabalhado e ressignificado. Não se trata de algo homogêneo onde todos compartilham das mesmas opiniões elevadas. Frequentemente é um lugar de conflito onde ideias podem bater de frente e serem discutidas e elaboradas por todos. Discussões variam de onde cada um coloca sua cadeira até quem toca forte demais ou por muito tempo seguido. Estas atitudes são capazes de criar relações de dominação no interior do grupo e frequentemente geram reações fortes. Em um grupo grande discute-se por cadeira, tomada, segundos de silêncio, canais na mesa de som, espaço sonoro, etc. Todos estes fatores podem determinar questões importantes como se alguém será ouvido ou não. As soluções precisam ser encontradas de maneira coletiva, a cada situação, e inevitavelmente haverá dias em que pessoas se frustrarão.

Diversos fatores podem levar a esta ou àquela definição, como a maior legitimidade de certos discursos em relação a outros. A circulação dos discursos é regulada por diversos fatores como mostra Foucault em sua fala inaugural no Collège de France editado em livro sob o título de A ordem do discurso. No caso de grupos de improvisação livre, podemos especular que o tempo de casa de determinados músicos é um fator que pode gerar uma legitimidade diferenciada para a circulação deste discurso ao passo que novos integrantes podem ter dificuldade para achar um espaço para sua voz. Suponho que mulheres nesta situação de desvantagem numérica encontrem ainda mais obstáculos. As estratégias para contornar estas situações são limitadas e até esforços bemintencionados às vezes deixam passar atitudes que cerceiam determinados discursos.

As relações interpessoais dos grupos dos quais participo lidam com este desconforto inicial inevitável de diferentes formas. Na OE há uma ética de acolher um transito grande de musicistas que passam para visitar, e/ou ficar um tempo. Simultaneamente, há um sentido de grupo bastante forte entre integrantes que estão há 
algum tempo, por mais que saiam e voltem. Este esforço coletivo e localizado de criar um espaço de interação no qual todos os discursos possam circular em igualdade e por meio deste esforço transformar em nos mesmos o que acreditamos necessário, é o que caracteriza, ao meu ver, a IL como heterotopia.

Ouvi falar certa vez de um grupo de improvisação livre no qual por decreto as mulheres sempre tocavam antes dos homens. Infelizmente nunca consegui saber mais sobre este caso peculiar. A princípio, tendo a especular alguns cenários e logo surgem perguntas. Primeiramente, não entendo porque estas mulheres querem continuar tocando com estes homens nem como impuseram a tal regra de tocar primeiro. Estariam as mulheres deste grupo na rara condição de maioria sendo assim capazes de impor este ambiente altamente normativo (o que seria estranho em IL) para esta minoria masculina? Elas os manteriam no grupo por acharem suas contribuições musicais indispensáveis? Por acreditarem que podem ajudar estes homens em um processo de desconstrução? Outra possibilidade parece ser uma obrigação da qual ninguém pode fugir e uma figura externa que controla tudo. Neste caso, acho muito pouco provável que a situação seja proveitosa para qualquer pessoa envolvida.

A questão de os homens não escutarem as mulheres, caso tenha sido esta a motivação da norma, permaneceria possivelmente igual ou pioraria severamente já que o único momento em que o rapaz teria que ter qualquer tipo de atenção às moças seria para perceber que elas não estão mais tocando (se é que isso também não é definido de maneira coercitiva com regências e/ou partituras). Podemos também especular que a decisão pela norma não tenha partido de um conflito e sim de um acordo interno com objetivo de experimentar e mostrar outras formas de hierarquia e dominação alternativas ao machismo. Seja como for, são indispensáveis as estratégias para combater o muito que ainda existe de opressão sobre as mulheres em todos os âmbitos, inclusive dentro da improvisação livre.

Processos feministas de tomada de consciência e atuação sobre si, como afirma McLaren, não só possibilitam a atuação da mulher sobre si, como podem ser considerados uma prática de transformação de si e da sociedade. O trabalho de desconstrução de determinados padrões de comportamento, sejam sonoros ou sociais, exige constante reiteração para si dos valores considerados verdadeiros e abertura para o outro. No entanto, estas práticas modificam as formas de interação e deixam marcas que 
se estendem por outros territórios e modificam sensibilidades. A filósofa Margaret McLaren afirma:

Práticas de si são sempre feitas com referência a um objetivo particular. Sugiro que a tomada de consciência pode ser vista como uma prática feminista de si, discutindo como a tomada de consciência como uma prática de si promove a transformação individual, bem como a coletiva. (MCLAREN, 2016:29)

McLaren nos chama atenção a novas formas de subjetivação vindas de uma constituição ativa do sujeito. A filósofa ampara-se no trabalho de Michel Foucault para afirmar que estas ações individuais estão intimamente ligadas a mudanças estruturais na sociedade. Para McLaren a transformação social em larga escala e a transformação individual dependem uma da outra, como aponta a autora no último capítulo de seu livro Foucault, Feminismo e Subjetividade.

Modular as subjetividades de músicos, como se busca nos processos das artistas que descrevi, certamente, não é simples mas pode gerar efeitos bastante positivos que se estendem para além dos domínios da improvisação e da música: uma escuta cuidadosa que sabe dar e receber silêncio; uma capacidade de ação eficiente sem planejamento quando necessário; a não repetição de valores competitivos e hierárquicos; a não reprodução de uma lógica industrial segundo a qual poucas pessoas tomam decisões por muitas e dão todas as ordens sem sequer tocar o produto final, enquanto as outras se ocupam de reproduzir alienadamente algum detalhe predeterminado do produto; relações igualitárias não normativas; o esperado derramamento destes valores e seus efeitos para a vida social de cada musicista. O grupo de improvisação livre articula o desenvolvimento das habilidades e virtudes e apresenta sempre um resultado estético das negociações intersubjetivas que acontecem e se desfazem em tempo real. Pauline Oliveros e Chefa Alonso trazem em suas obras uma importante contribuição para a criação de um mundo mais igualitário e respeitoso. Ambas oferecem também caminhos, práticas e exercícios que podem ajudar neste sentido. 


\section{Modelos e referências}

As lutas feministas, além da conquista de importantes direitos de atuação direta na sociedade e sobre o próprio corpo, criaram e continuam a criar redes como maneira de permitir maior acesso à produção de mulheres compositoras e improvisadoras. Um exemplo de um coletivo que trabalha neste sentido é a Rede Sonora ${ }^{85}$. Esta rede colaborativa de artistas e "pesquisadorxs", ligada à Universidade de São Paulo, realiza diversos eventos e atividades, acadêmicas e artísticas, relacionadas à necessidade de dar visibilidade a trabalhos de mulheres. É necessário o debate e são necessárias referências femininas na formação de musicistas homens e mulheres.

Gostaria também de citar alguns nomes que fizeram parte da composição deste trabalho pela importância que tiveram para o movimento artístico estudado. As artistas e grupos listados abaixo de forma alguma resumem o que existe de improvisação livre feita por mulheres, principalmente hoje em dia em que este movimento se encontra, assim como os feminismos, em franca expansão. São, em boa parte, referências de mulheres que praticavam esta forma de fazer música na época que

85 http://www.sonora.me/ 
se costuma apontar o seu surgimento. Parte dos grupos deixou de existir e nem todas as mulheres listadas continuam interessadas em improvisação. Contudo, são nomes que talvez sejam menos conhecidos e documentados do que poderiam, ou deveriam, em função de sua relevância histórica.

Com exceção dos grupos Spontaneous Music Ensemble e Henry Cow, todos os outros são formados exclusivamente por mulheres. Embora Henry Cow também não seja propriamente um grupo de improvisação livre, a presença de figuras importantes deste movimento, como Fred Frith e musicistas do Feminist Improvising Group (FIG), além das frequentes incursões por esta forma de fazer música, tornam o grupo relevante para esta lista. A lista que segue também não faz jus à totalidade das mulheres que praticavam improvisação no período em questão ou se propõe a dar conta de todos os grupos musicais dos quais estas artistas fizeram parte. Apenas aponta caminhos iniciais para a leitora ou leitor que se interessar por adentrá-los. Seguem os nomes das musicistas e alguns dos grupos dos quais fizeram ou fazem parte:

Pauline Oliveros - Women's Ensemble; The Circle Trio; The New Circle Five.

Lindsay Cooper - Feminist Improvising Group (FIG); Henry Cow; European Women's improvising Group (EWIG).

Georgina Born - Feminist Improvising Group (FIG); Henry Cow.

Magie Nichols - Feminist Improvising Group (FIG); Henry Cow; Les Diaboliques; Contradictions; Spontaneous Music Ensemble.

Irène Schweizer - European Women's improvising Group (EWIG); Les Diaboliques

Joëlle Léandre - European Women's improvising Group (EWIG); Les Diaboliques 


\section{Conclusões da terceira seção}

Assim como ressalta Rago quando diz que o feminismo ainda está longe de ter suas metas alcançadas, a improvisação livre ainda é um território ocupado quase sempre por homens. O que também chama atenção é que em outros círculos musicais a presença feminina é ainda mais reduzida. Talvez meu olhar sobre a improvisação livre como um espaço um pouco mais filógino venha da diferença que observei entre esta e minhas experiências musicais quase exclusivamente masculinas em bandas adolescentes, ou meus colegas de turma no curso de Música Popular na Universidade Estadual de Campinas entre os quais havia vinte e tantos homens e uma mulher.

Acredito que a presença feminina embora ainda insuficiente, precisa ser observada nos espaços onde ela parece existir de forma diferente do comum. No primeiro ensaio do qual participei com a Orquestra Errante havia paridade. Isto sem dúvida chamou minha atenção. Nunca havia tocado com tantas mulheres. Creio que caiba aos desdobramentos deste trabalho, conhecer estudos que investigam a presença de mulheres na música e um aprofundamento em estudos feministas e de gênero. Ainda que a minha pesquisa represente um recorte pequeno destes universos em aparente expansão, isto é, a improvisação livre e os feminismos, e este relato indique apenas o começo de um 
processo, os cruzamentos que se apontam sugerem perguntas relevantes para as quais não possuo respostas e por isso devem ser feitas. Este relato/reflexão sobre a minha experiência pessoal, não pretende criar ou oferecer verdades gerais e comprováveis, ou esboça qualquer tentativa de estabelecer um estado geral da improvisação livre ou dos feminismos. Espero somente conseguir narrar com clareza como as questões feministas vieram a ocupar posição de tamanha importância em uma pesquisa que não as previa, além de esboçar um começo de trilha que buscará compreender melhor as relações entre estas correntes. Espero que as questões levantadas possam ajudar neste sentido. O momento das conquistas feministas e práticas improvisatórias, considerando ambas como práticas de reinvenção, indica que novas gerações poderão crescer com formas de subjetivação e constituição de si, mais criativas, menos bélicas e em constante busca de liberdade. 


\section{CONCLUSÕES GERAIS}

Inicialmente me propus a investigar processos de preparação para improvisação livre, com a impressão de que haveria semelhanças com as práticas de cuidado de si descritas por Michel Foucault. Estas relações são objeto principal da primeira seção do texto. Na seção seguinte, descrevi um experimento realizado com a Orquestra Errante e a partir das questões que motivaram a pesquisa refleti sobre os relatos das pessoas que participaram do experimento, e sobre as entrevistas com as três improvisadoras. A partir da maneira como esta pesquisa se desdobrou, relações de mulheres com o cuidado de si e com a improvisação livre mostraram-se relevantes ao ponto de comporem a terceira seção da dissertação.

Algumas conclusões importantes deste trabalho estão espalhadas por essas três seções, especialmente nos finais. O que caberia então dizer na conclusão geral? O que atravessa as três seções? Pois parece notável que as práticas de subjetivação, na maneira como são descritas nas referências desta pesquisa, sempre envolvem um processo continuado de trabalho sobre si. E parece ser nesta continuidade que podemos observar a transformação do sujeito. 
Gilberto Gil (1972) escreveu em sua canção Oriente, as palavras “a aranha vive do que tece". Quem já observou uma teia de aranha ao longo de um tempo, talvez tenha percebido que os cuidados de sua dona são constantes. Para que esta ferramenta complexa e eficiente funcione, é necessário reiterado esforço. O estrago feito por fatores externos, ou pela própria aranha em sua caça, demandam remendos frequentes. Mas quais seriam os remendos necessários a musicistas de IL?

Falei, no decorrer desta dissertação sobre alguns hábitos que segundo nossas referências dificultam processo de criação coletiva. Falei, na primeira seção, sobre a tagarelice como vista por Michel Foucault e Chefa Alonso. Na segunda, descrevi os comportamentos vai um de nós e o instinto salva-vidas, além das reflexões de Pauline Oliveros sobre a necessidade de combater expectativas no momento da improvisação e as dificuldades com os silêncios. Na terceira seção, a autora também relata a frequente opressão simbólica às mulheres em ambientes musicais e improvisatórios.

Estas questões foram levantadas para reiterar a necessidade de constante atenção, mas também para mostrar justamente que nesta prática há autores e autoras, grupos, orquestras e ambientes pedagógicos que já tratam destas questões, e buscam estratégias e saídas, ainda que não organizem as práticas que compõem estes trabalhos sob o nome de cuidado de si.

As quatro principais referências musicais deste trabalho, isto é, Pauline Oliveros, Chefa Alonso, Susan Alcorn e Rogério Costa, oferecem reflexões, práticas e ferramentas pedagógicas que certamente podem ser aprofundadas. Contudo, espero ter conseguido oferecer um olhar para estas obras que contribua para outras reflexões e processos além do meu.

Outros autores dentro do campo da música como Cobussen, Cardew, Koellreuter e Falleiros também se mostraram vitais para este trabalho como maneiras de olhar para o ambiente da improvisação, e buscar estratégias para contornar suas dificuldades.

A filosofia de Deleuze, principalmente nas relações que Costa estabelece com a música, as ideias sobre subjetividade de Guattari e Rolnik, além das reflexões de Foucault e outros filósofos e filósofas sobre práticas de subjetivação foram determinantes para todo o processo de pesquisa. 
Outras referências que pensam a subjetividade e a preparação no campo do teatro e da performance art, como Ferracini e Quilici, também foram fundamentais no sentido que fazem uma ponte entre os processos de ascese filosóficas e os processos artísticos que descrevi.

Creio que tanto as referências artísticas quanto filosóficas aqui citadas entendem que a subjetivação não é um processo que gera um resultado a partir do qual se pode relaxar e apenas ser a pessoa boa que se acredita ser. Não se trata de pessimismo. É de se imaginar que o trabalho só continue porque há necessidade. Continuamos com lugares comuns nos quais incorremos.

Tocamos às vezes mais do que gostaríamos, o nível de concentração varia de um dia para o outro, de uma música para a outra. A atenção aos nossos cacoetes oscila. É como manter boa postura corporal. Muitas vezes entendemos a importância de abrir os ombros e alinhar a coluna, mas também temos prazer em relaxar os ombros e deixar o abdome para frente.

Da mesma forma, quando tocamos, sabemos da importância de dar espaço aos demais, mas o prazer de fazer parte da música em devir frequentemente nos convence a tocar. Acredito que isso talvez seja um pouco diferente daquilo que combatemos na ascese, mas acredito também que se nos descuidamos, o mato cresce à nossa volta e perdemos de vista se estamos impedindo que outras energias surjam.

Relaxar os ombros, ou deixar-se levar pelo fluxo não são, a meu ver, problemas, se não forem a regra. Pelo contrário, é indispensável saber relaxar. Também o envolvimento e a sensação de entrega frequentemente presentes na situação musical descrita, são parte fundamental do que alimenta o desejo de improvisar. O prazer e a entrega ao momento parecem ser motor e combustível da maioria dos grupos de improvisação que conheço.

Acredito que os pressupostos éticos destes grupos são o que mantém esta máquina funcionando. São eles que lembram a quem toca, da importância da escuta, da atenção ao todo e da não sujeição do discurso do outro. Assim, a experiência continua criativa e prazerosa para todas as pessoas envolvidas.

Pudemos ver no experimento com a OE que processos bem-sucedidos nesse sentido podem transbordar questões éticas e estéticas para além das pessoas que 
tocam. Por este motivo, acredito que futuros desdobramentos desta pesquisa devem prever também um tempo de fala para estas pessoas que não tocaram, mas estavam presentes e sentiram-se representadas pelas questões levantadas, ou pela música criada a partir do exercício.

A opção do pesquisador foi, nesse experimento, por colher apenas os relatos que partiram da experiência de realização de exercícios, e não pela reflexão das outras pessoas que, como eu, observaram. Embora estas certamente poderiam enriquecer muito a pesquisa. Com um número maior de encontros com grupos de improvisação, e um tempo maior de pesquisa, acredito que estes experimentos podem gerar reflexões importantes.

Mas voltando à questão do porque, afinal, nos preparamos, ou seja, o que vemos necessário transformar em nós mesmos, acredito que este processo não deva ser de lamentação pelos nossos tiques sociais e musicais. Musicistas nem sempre encontram o tão desejado acordo sonoro, e a improvisação nem sempre "dá certo". Frequentemente "dá certo" para alguns e para outros não. Nem por isso é melhor ou pior.

Acredito que a construção de uma subjetividade criativa e mais livre, ou a desconstrução das subjetividades serializadas, como descreve Guattari, possuem forte relação com o que amiúde se pretende construir na improvisação livre. Os sujeitos que se envolvem nestes processos não atingem um ponto no qual bastam exercícios de manutenção.

A palavra cultivo, usada por Quilici (2011), pode nos remeter também à ideia de um jardim. Não há uma ação definitiva que possa ser feita. A grama crescerá, as outras plantas também, algumas morrerão ou secarão com as estações, ou serão alvo de pragas, ou precisarão de mais ou menos sol, água, adubação, etc. Shunryu Suzuki refere-se ao processo de meditação como "retirar as ervas daninhas da mente" (SUZUKI, 1994:34). Segundo o autor, são elas que nos permitem crescer. Sendo assim, lembrar delas, observá-las é, para Suzuki, um processo que contribui grandemente para a prática. O autor escreve:

Costuma-se dizer que "arrancando as ervas daninhas alimentamos as plantas". Nós arrancamos as ervas daninhas e as enterramos junto às plantas para nutri-las. Portanto, mesmo que você tenha dificuldade em sua prática, mesmo que haja algumas ondas enquanto está sentado, essas mesmas ondas servirão para ajudá-lo. Assim, não deve aborrecer-se por causa de sua mente. Ao contrário, fique grato às ervas daninhas porque elas vão, afinal, enriquecer sua prática. Se você tiver alguma experiência de 
como as ervas daninhas se transformam em alimento mental, sua prática fará progressos notáveis. (SUZUKI, 1994:35).

As "ondas" citadas pelo autor podem ser pensadas, no caso da IL e da interação cotidiana, como as nossas recorrências menos desejáveis. Para Suzuki, estas seriam alimento mental para o processo de subjetivação e não um tormento, como às vezes somos ensinados a pensar sobre nossas falhas.

Estamos em constante transformação. Olhar para si não é um ato pontual. Faz parte de um movimento constante que envolve além de olhar-se, tomar decisões a respeito de si mesmo, experimentar caminhos, avaliá-los, errar, tomar novas decisões, e assim por diante.

Nas artes orientais, referência para Pauline Oliveros e Cassiano Sydow Quilici, encontramos menção à inevitável reiteração dos erros e deslizes na nossa vida cotidiana. Shunryu Suzuki (1994) refere-se a Dogen, fundador da escola soto zen, para apresentar a expressão Shoshaku jushaku. Suzuki escreve:

Shaku geralmente significa "erro" ou "engano". Shoshaku jushaku significa "suceder um erro ao outro", ou seja, um engano contínuo. Segundo Dogen, um engano contínuo também pode ser Zen. A vida de um mestre Zen, poder-se-ia dizer, é feita de muitos anos de shoshaku jushaku. Isso quer dizer muitos anos de esforço decidido. (SUZUKI, 1994:38)

Esta expressão, portanto, não deve sugerir qualquer tipo de pessimismo, e sim aliviar o peso do erro inevitável, e voltar o foco para a continuidade tranquila das práticas de subjetivação. Tentei mostrar, que estas podem ocupar posição central na vida de musicistas de improvisação, e que variam consideravelmente de uma pessoa para outra.

Escrevi também sobre como algumas das descobertas da pesquisa afetaram meu próprio processo de preparação e a maneira como compreendo o instrumento que toco. Cabe mencionar que este processo trouxe também uma maior atenção a questões como os feminismos, a sujeição de um discurso por outro e os nossos automatismos.

Longe de ter resolvido qualquer uma dessas questões, esta atenção deve servir apenas para me tornar mais apto a perceber como se manifestam em mim, e tomar caminhos que busquem transformar o que precisar ser transformado. Igualmente, penso 
que a construção de processos como este passa necessariamente pelo julgamento de cada um ou uma, acerca do que é ou não necessário.

Por fim, acredito que podemos encontrar indícios de caminhos, mas todos precisam ser aprofundados experimentados em seu caráter processual para que compreendamos as maneiras como atuam sobre nós. Assim cada musicista em seu processo de olhar para si deve, segundo vimos, compor seus processos de preparação, que serão certamente singulares e dinâmicos, e refletir constantemente sobre eles. Espero ter contribuído com algumas ideias. 


\section{BIBLIOGRAFIA}

ALONSO, C. Enseñanza y aprendizaje de la improvisación libre: propostas y reflexiones, Alpuerto, Madrid, 2014

Acordes, 2008 Improvisación Libre: la composición en movimiento, Espanha: Dos

ARTAUD, A. O Teatro e Seu Duplo. São Paulo: Martins Fontes, 2006

ALPERSON, Philip. On musical improvisation, USA, Blackwell Publishing. 1984.

BAILEY, Derek. Improvisation its nature and practice in music, Da Capo Press, USA, 1993.

BERKOWITZ, A. The Improvising Mind - Cognition and Creativity in the Musical Moment. New York: Oxford University Press. 2010

BERLINER, P. Thinking in Jazz - The infinite art of improvisation, Chicago: The University of Chicago Press, 1994.

BRAXTON, Anthony. Entrevista para o site especializado Tomajazz: http://www.tomajazz.com/perfiles/braxton_2007_eng.htm. Acessado em 10 de outubro, 2015.

BRECHT, B. A peça didática de Baden-Baden sobre o acordo, Teatro Completo, vol. 3. 2. Ed. São Paulo: Paz Terra, 1992 p. 187-211. 
BRITO, Teca. Koellreutter Educador: o humano como objetivo da educação musical. São Paulo: Peirópolis, 2001.

CAGE, John (1976) - Silence. Middletown, Connecticut: Wesleyan University Press (1985) - De segunda a um ano; tradução Rogério Duprat. São Paulo:

Hucitec .

CARDEW, Cornelius. On the Role of the Instructions in the Interpretation of Indeterminate music in: Treatise Handbook, xiv-xvi, London, Edition Peters, 1971.

CHAN, Charity. An interview with Fred Frith: The teaching of contemporary improvisation. Oakland, Critical Studies in Improvisation / Études critiques en improvisation, Vol 3, No 2 (2007).

COBUSSEN, Marcel. The field of musical improvisation. Leiden, Leiden University Press, 2017.

COSTA, Rogério Luiz Moraes. O músico enquanto meio e os territórios da livre improvisação. PhD diss., Pontifícia Universidade Católica de São Paolo, 2003.

Estratégias pedagógicas para a prática da improvisação livre: diálogos entre a improvisação e a composição. São Paulo. USP, 2010

IAZZETTA, Fernando; VILLAVICÊNCIO, Cesar. - Fundamentos técnicos e conceituais da livre improvisação in KELLER, D., QUARANTA, D. \& SIGAL, R., (eds.). Special Volume Sonic Ideas: Musical Creativity (Volume Especial Sonic Ideas: Criatividade Musical), Vol. 10. Morelia, Michoacán: Centro Mexicano para la Música y las Artes Sonoras - CMMAS. Sonic Ideas, v. 10, 2013. P. 120.

Schaub, S. Expanding the concepts of knowledge base and referent in the context of collective free improvisation. XXIII Congresso da Anppom. Natal, 2013

A improvisação livre, a construção do som e a utilização das novas tecnologias, São Paulo, USP, 2015.

Fapesp, 2016.

Música Errante: O jogo da improvisação livre. São Paulo: Perspectiva:

COX, Christoph; WARNER, Daniel. (org.) Audio Culture: Readings in Modern Music, USA, Continuum, 2004.

DELEUZE, Gilles; GUATTARI, Félix. Mil Platôs. v.1, São Paulo, Editora 34, 1995. Mil Platôs. v.2, São Paulo, Editora 34, 1995.

FALLEIROS, Manuel Silveira. Palavras sem discurso: estratégias criativas na livre improvisação. Phd. diss. Universidade de São Paulo, São Paulo, 2012.

FARACO, Carlos A. Linguagem e diálogo As ideias linguísticas do círculo de Bakhtin São Paulo: Parábola Editorial, 2009.

FERREIRA, A. G. Dicionário de Português/Latim. Porto: Porto Editora, 1996.

FOUCAULT, Michel. A hermenêutica do sujeito. São Paulo: Martins Fontes, 2006. 
A ordem do discurso. São Paulo: Loyola, 2007

GOEHR, Lydia. The Imaginary museum of musical works, USA: Clarendon Press Oxford, New York, 1992.

GROTOWSKI, J.; BARBA, E.; FLASZEN, L. O Teatro laboratório de Jerzy Grotowski 1959-1969. São Paulo: Sesc/Perspectiva, 2010.

GROUT, Donald J. A History of Western Music, USA: Norton, 2009.

HAMILTON, Andy. The art of improvisation and the aesthetics of imperfection In: British Journal of Aesthetics, Vol. 40, No 1, Oxford University Press, Inglaterra, 2000, p. 168-185

KANELLOPULOS, Panagiotis A. Freedom and Responsability: The Aesthetics of Free Musical Improvisation and Its Educational Implications - A view from Bakhtin In: Philosophy of Music Education Review Vol. 19, No. 2, p. 113-135, Indiana University Press, 2011.

LEWIS, George E. Improvised Music After 1950: Afrological and Eurological Perspectives, Chicago, Black Music Research Journal, 2002.

MCLAREN, M. Foucault, Feminismo e Subjetividade. São Paulo: Editora Intermeios, 2016.

MCMULLEN, T. Improvisation within a scene of constraint: An interview with Judith Butler. In: SIDDALL, G; WATERMAN, E. (Orgs.) Negotiated Moments: Improvisation, sound and Subjectivity, Durham: Duke University Press, 2016. p. 21-35

MINGUS, C. Saindo da Sarjeta. Rio de Janeiro. Jorge Zahar Editor: 2005

NAZARIO, Luciano Da Costa. Práticas de criação musical em ambientes de ensino coletivo aplicando processos heurísticos: uma teoria substantiva. Phd. diss. Universidade Estadual de Campinas, Campinas, SP, 2017

OLIVEROS, P. Deep listening: A composer's sound practice. Lincoln: Deep Listening, 2005.

Harmonic Anatomy: Women in improvisation. In: FISCHLIN, D; HEBLE, A. (Orgs.) The other side of nowhere: Jazz improvisations and community dialogue. Middletown: Wesleyan University, 2004. P. 50-70

PADOVANI, J.H. e FERRAZ, S.. Proto-história, evolução e situação atual das técnicas estendidas na criação musical e na performance. Música Hodie, v.11, n.2. Goiânia: UFGo, 2012.

PARKER, William. Conversations, USA: Rogue Art, 2011.

Who owns Music?, USA, Buddy's Knife Jazzedition, 2008.

POUPART, Jean et al. A pesquisa qualitativa: enfoques epistemológicos $e$ metodológicos. 2ed. Petrópolis: Vozes, 2010.

PRESSING, Jeff. Psychological Constraints on Improvisational Expertise and Communication, in In the course of Performance: Studies in the World of Musical 
Improvisation. Ed. Bruno Nettl and Melinda Russel Chicago, (University of Chicago Press, 1998)

Cognitive Processes in Improvisation, in Cognitive Processes in the Perception of Art, ed. W. Ray Crozier and Anthony J. Chapman (Amsterdam: Elsevier, 1984), 346 - 347.

RAGO, M. Feminismo e Subjetividade em Tempos Pós-Modernos. In: LIMA, C. C.; SCHMIDT S. P. (Orgs). Poéticas e Políticas Feministas. Florianópolis: Editora das Mulheres, 2004. p. 31-41

Novos modos de subjetivar: a experiência da organização Mujeres Libres na Revolução Espanhola. In: Revista Estudos Feministas, v.16, n.1, Florianópolis: UFSC, 2008 .

Foucault, a Subjetividade e as Heterotopias Feministas, In: SCAVONE, L; MISKOLCI, R; ALVAREZ, M.C. - O legado de Foucault, SP: Unesp, 2006, pp 101-118

ROSA, Maria Virgínia F. P. C.; ARNOLDI, Marlene A. G. C. (orgs.). A entrevista na pesquisa qualitativa: mecanismos para validação dos resultados. Belo Horizonte: Autêntica, 2008.

RZEWSKI, Frederic. Little Bangs: A Nihilist Theory of Improvisation, USA, Current Musicology, Columbia University Libraries, 1999.

SAVOURET, Alain. Introduction à un solfège de l'audible: l'improvisation libre comme outil pratique, Lyon: Symétrie, 2010

SAWYER, Keith. Group Creativity Music, Theatre, Collaboration. New Jersey. Lawrence Erlmaum Associates, Publishers. 2003

Improvisation and the Creative Process in: The Journal of Aesthetics and Art Criticism, Vol. 58, Mo. 2, USA, Blackwell, 2000.

SCHAEFFER, Pierre (1988) - Tratado de los objetos musicales. Tradução espanhola Araceli Cabezón de Diego. Madrid: Alianza Música.

SLOTERDIJK, P. Has de cambiar tu vida. Valencia: Pre-Textos, 2012.

STANISLAVSKI, C. A Preparação do ator. Rio de Janeiro: Civilização Brasileira, 1989.

SUZUKI, D.T. Essays in Zen Buddhism. Londres: Rider \& Company, 1949, p.18.

SUZUKI, Shunryu. Zen mind, beginner's mind. San Francisco: Weatherhill, 1970.

TAMM, E. Robert Fripp From King Crimson to Guitar Craft. UK: Faber and Faber, 1990

WOODCOCK, George. (org.) Grandes escritos anarquistas, Porto Alegre: L \& PM Editores, 1981. 


\section{ANEXO I - ENTREVISTAS}

\section{Pauline Oliveros - 20/06/2016}

Pauline: Improvisation as far as I'm concerned has a very wide range. It's like composition. Composition you can't say composition and then know what it's going to be like. You can only think that composition is something someone has constructed someway, but you don't necessarily know what it is until you hear it or see a score and then you might be able to prepare yourself to listen to the composition. But if you have a very firm preconceived idea of what a composition is or what an improvisation should be then you may run into some difficulty if it doesn't conform to your idea or your thought process. So, in my world, preparation is to free yourself from your own thoughts and ideas about expectation. One of the phrases that I really like to avoid is, or I mean, which I don't like actually, is "I didn't know what to expect" and right there that's a loss of freedom because if you have an expectation of what the improvisation is going to be or should be then you are not free. So, the first part is how to free yourself from that kind of thinking. And that actually means free yourself from thinking.

Pedro: Sonic Meditaions.

Pauline: Well, in my sonic meditation or deep listening whichever way you want to call it, the process is exactly what I've been saying. To free yourself from thought and free yourself of judgement, from judging, free yourself of criticizing. Free yourself of analysing. And this is preparation for listening. And listening is giving attention to whatever is, whatever is happening, whatever sounds are happening, anything that is happening. Anything that you can sense in any way. And so it's opening your senses to 
receive and actually become receptive. So, in this kind of listening then you begin to expand your consciousness. In my approach to improvisation that's the place where I begin to improvise, and I want to be able to allow my body which is very thoughtful in many ways to produce the sounds it wants to produce. And then I'm free in the improvisation because I am receptive at the same time as I am active.

Pedro: Successful improvisation.

Pauline: It involves a trust. And the trust is of your own possibilities, of your own actions. Pedro: Lack of silence.

Pauline: Well I think one possibility is to play to the silence. And if you start from silence then can you give silence as well as take silence is a question. So that's something for the group to explore. And if you start with a listening meditation then you're not making sound. You are listening to sound. So it's also important to listen to silence. If there is any. Because there's always something. Can you base your improvisation on what your hearing? What it is that the environment is doing. Can you get an improvisation to feel as if the sounds around you are right. That's fun actually. I think it helps a lot to improvise without instruments and then gradually introduce them. All of these things it helps if they're spontaneous. There's no rule. It's just suggestion.

Pedro: Using or not instruments.

Pauline: Well, that can be an agreement. Can we do this without instruments. Find out what happens.

Pedro: Long improvisations.

Pauline: 12 hours, 24 hours, 12 hours straight. I've done that. Not recently but I have. I've done it as a solo but I can also have...there have been times when there have been a group improvisation of that nature as well. But I would say that they're pretty much committed to deep listening or sonic meditation.

Pedro: Improvisation and written music.

Pauline: Certainly all your experience is part of who you are. And we store our memories, or we seem to. We remember things. Those things come up. But the process that I'm talking about, that I've described to you so far is different from reading music because the sense is from eye to ear, or it could be from eye to body to ear, or not even ear but mind, to the audio cortex where listening takes place. It's not the ear that listens. The ear gathers sound information, so there's a delay. And there's further delay if you start thinking and analysing and criticizing. That takes you away from listening. So what I've been working with, I think, is spontaneity, which means that the body reacts and it reacts much faster than you can if you're thinking or reading or doing any form of criticizing, analysing or so forth. So I'm trying to get a direct response from my body when I improvise. I think we're trying to get that when we're reading music as well but reading music then gives us to opportunity to go back and read it again. Improvisation does not do that. I could say it's direct, unless you are working from memory. You know, working from thought. What you're thinking you're gonna do. Like for example, maybe you have a bunch of licks that you've stored up. And that you play these licks when you have the opportunity then that's not spontaneous but it can be done spontaneously but it slows you down.

Pedro: Life and music.

Pauline: Although we're required to provide a syllabus (19:05), you know, for class time, I'm still teaching at Reseller institute but I never know what is really possible to do with the students until I see them. Until I understand who is in my class. So there is always an improvisatory activity of finding out who the students are and finding out what is gonna work with them. Finding out how to go about this and how to get them into deep listening, cause I teach deep listening at RPI (Reseller Polytechnic institute) and have done that for 
fifteen years now. And it's very interesting because most of the students who are in my class are engineers. It's a technical school. It's not an engineering course. It's a course that engineers take in the arts. It's primarily an engineering school and then we have the division of humanities and the arts department is in that division. But listen to this, there's no music department, and there's no arts department. But all of us are together as an integrated electronic arts faculty. Even though drawing is taught, painting is taught, music theory is taught, all of that. But we're in the process now of forming a new music curriculum in which deep listening is part of it. So it's going to be a different kind of music department. But it's coming out of all of our experience of being in this together. And we have arts across the curriculum and collaborations with other faculties in other departments. I worked a lot with the architecture department ever since I've been there. And there's an excellent course, a programme called sonic art and it has a lot of musicians taking that, going to that programme, so they also take my seminars and so on. But for my seminars it's the same thing. I have to know who is going to be in there before I can really know how we move and how we learn. But the most important thing for me is getting the students to be active in the sense of what they are wanting to learn.

Pedro: How do these engineers come to your class?

Pauline: They come to my class saying "I didn't know what to expect" (laughter). And then they get something that they didn't expect. So that's my life.

Pedro: External situations.

Pauline: I try to maintain that [improvisation] in my life whether things are good or bad, I mean, right now we have a rather difficult national situation going on with the presidential election and there's a sense of danger that we could have a president that doesn't know what he is doing. He's very bigoted. It could be a dreadful situation to have that happening but we have other opportunities, other possibilities as well. I try to simply take in what is going on and not get...(pause)...even though I feel the danger. There are so many people who are racists and have hateful attitudes so one of the things that's happened, I think, is that this person, I'm talking about Donald Trump, has uncovered these people. They are more visible than they have been. That visibility gives you the opportunity to show something else and you have to know about the danger and what it is. Or face it. Face it straight on. But yesterday I had a very good day of about five hours of improvisation with two other people. We were recording so that was good.

Pedro: Practices outside of music

Pauline: One of the practices that I got involves with actually when I was about forty, was Karate. I practice Karate and did achieve a black belt and I found that very beneficial and I translated a lot of what I learned into my practice. I also studied Tai-Chi and Chi Kung. Those practices have been very beneficial I'd say, but more than that I learned from Elaine Summers who was a choreographer and a film maker actually and a very long time friend who passed away a couple of years ago now, but I learned from her before any of the others I learned kinetic awareness. She taught about the energy of the body which has also been a very important part of my practice.

Pedro: Other thoughts?

Pauline: Don't think too much. Do! 


\section{Susan Alcorn - 13/07/2016}

Susan: Let's start with the preparation, the musical preparation for improvisation. Like you mentioned, preparing for an improvised performance is quite different, though not completely different than preparing for playing out of a score. When I play music like, for example, I'm working on something now, an octet that I'll be playing next month, which is difficult for me. So that's basically all I do. Practice that over and over again and try to learn it specifically. And then maybe find different ways to phrase things to make them more musical or whatever. With an improvisation, I don't prepare as much. Although part of what I do is, I will play scales just kind of freely improvise at home. Or maybe play melodies. I'll think about structures as in small structures, for example. Something that's in a whole tone kind of thing or how best to use minor seconds or just major seconds. I will kind of go through chords that I like or different parts of chords that I think kind of sound good, that sort of thing. Not that any of that will necessarily be used in an improvisation because when I'm involved in strictly improvisation, and that's mostly with other people, it kind of flies out the window. What I do during a performance is I listen and as you know you don't often get the opportunity to know the people you're playing with before you get up there and play or discuss anything which in some ways is a good thing because you get to know them as a person through their music and that part of themselves. So, what I do is, I just listen to what other people are doing. I try to take into account the audience because you're playing for an audience. It's not just us having fun up there although it is. I try to take into account the space, the room, my moods or feelings, although I don't know if that's something you can control or what. So, improvisation for me, it's like, it's a group. 2 or 3 maybe 50, you know, it's an improv orchestra. You're working together to, not working, you're fighting together, doing something together. And you make this...you evoke this beautiful, maybe like a flower or this beautiful and very difficult to define thing or spirit or whatever it is on the ether. It's just incredibly powerful but it's only there for, you know, when the music is going, when it's done, it's done. When you're creating that, when that's being created, sometimes that feels like it takes quite a bit of care to make sure it doesn't all sort of fall apart into just nonsense. So, if the improvisation is getting maybe what I would consider maybe too far out, or people are just playing things and there's nothing what I would call musical. To me musical is something that reaches a deeper part of yourself. Something that informs us in some way. And if that's not happening then sometimes I think maybe make it my business to find a way to make that happen.

Pedro: How does one develop these things?

Susan: One of the really great improvisers that I know and that I've kind of experienced enough so that I know maybe a little bit about them outside of just playing together, a lot of them will have some sort of thing that they do like tai-chi or meditation, will have some sort of practice in that regard. And I think that in life in general and in the practice room in specific I don't think one needs to develop these qualities. Specifically, concentration. I think that, and I don't think that it's different rehearsing, say, for an improvisation than it is rehearsing for, say you have to play something difficult in a performance situation, in concert, written music. You need to be able to concentrate, to keep your mind off of just wondering. Sometimes you get bored or you're thinking "what if I did this" or "oh, look who's here" or "I don't want them to think this of me". And I think that's something I need to cultivate. I try to practice that in my life, and that's of course, compassion, respect, if there's disagreement, finding piece and maybe understanding another point of view without judging, which of course are all things that you need to do in improvisation. 
Although I've met some people who are very kind and thoughtful and understanding and then when they get into improvisation they're just into doing their own thing. And it doesn't work. It's like you're playing with a record. What good is that? It doesn't change. They don't change what they're doing for other people. At least it appeared that way. So, I'm not sure that cultivating that outside of the music situation necessarily transfers over. But I think if you make it appoint in your musical life to take that into account and to just not think 'Oh, I've gotta trust, oh I've gotta, oh I've gotta respect, I've gotta organize beauty, I've gotta be angry or whatever. You don't think of those while you're playing. Just like you think "Oh, I'm playing a C minor scale". Well maybe you do, I mean, you're playing and you think "oh, there's a C minor scale". but with me I kind of look at it visually across my steel guitar and that kind of just makes connections whether I like it or not. So, I don't know if I answered your question but I think it's important to cultivate them. I think it's important to think about that or have that as your understanding when you're involved in a musical situation. And I think that's not something you can turn on and off. It's something you've gotta let it sink in. and of course, like with anything else the more you do it, the better you are at it. The more you're able to take those kinds of understanding of skills or your practice or your non-musical practice into a performance situation, the better you'll be at improvisation. A lot of people will be "oh, yeah! improvisation, that's cool! I could do that! Just mix sounds and whatever. Oh, it's fun." As you know because you're doing a master's on this. You know, it's something that is an art form and it takes time to get better at it.

Susan: Awareness of the total sound that's coming out and what's going on. Sometimes aware of the need in a.... like when something's going on, or while, like a musical motif. Awareness in improvisation when it's time to move on to something else. So, improvisation, you need both sides of the brain. One side has to think "well, ok, we need to get on to something else.

Pedro: Moving in and out of sound?

Susan: Well, let's say everybody is - this is not going to be very XXXX in writing - but say everybody is going turulíriturulirituruliri, ok, and say that's going on and it's like, ok, it's kind of getting on too much. So, maybe every time turuliri, and then you pooooooom ... and you...the words aren't coming out of my mouth...like

Pedro: sort of swaying form in another direction?

Susan: Yes! Because everything is form. Even in improvisation. In improvisation form is what comes out. Form is the same with anything. Form is just, it's mathematics, it's like, ok, this is what's going on. So, yeah, you're changing the form.

Pedro: non-improvised musics.

Susan: I think they both influence each other (improv. Vs. written) I don't know if I can describe it, but whatever skills that you need to play improvised music those are the same skills you need, really, at the bottom of it, I'll say it in Spanish, al fondo, is that, say you're playing a composed piece. How many ways there are to play that composed piece? Infinite. Infinite tiny little things you can do. These past couple of years I've been playing, when I do a solo set, I'll do a lot of improvisation and then I'll play some pieces that I write, and then I'll play maybe some Messiaen or some Piazzolla. With the Piazzolla every time I play it, it's different. Every time I play it I hear it differently. Every time there's these different emotions that come up. Not that emotions are necessarily a good or bad thing. But I just feel it differently and even tiny little things that you can do as a musician, without even thinking of it. Without even consciously "ok, I'm gonna play this note this way" and those are skills of improvisation perhaps that you bring to written work. From written work to improvisation, you bring some of the discipline, because there's so much discipline, in a certain way, when you're learning something off of a 
score. You have to play it note through note. And I think that helps you play your instrument better. The better you know your instrument the better you are to express yourself in both written and improvised music. As far as preparation...for example: next month, in about two and a half weeks from now, I'll be playing with Mary Halvorson, guitarist. She wrote a piece for an octet with two guitars in it.... It's rare that composers will write specifically for pedal steel guitar. So the music is great and I like her, I like playing it, and it's important that steel guitar, my instrument, gets involved in interesting music so I'm very... I wanna do this a lot, and I don't have a lot of experience playing composed music with groups. Mostly with me it's been solo, which is a much more scary in some ways, proposition... if you screw up, there you are, in front of the whole world. Again, if you want to go slower or faster or whatever, you can control that. When other people are playing you can't. So, this month, basically, for the most part I just work on the music that I'm gonna need for that gig, and then two weeks after that I have some gigs which is total improvisation because I've never played with before. So, I'll probably get into more scales and chords, and just listen to music that I like. I listen to music that affects me in some way deeply that I have a visceral response, reaction from. And maybe I'll play along with it. And maybe I'll learn certain sections that I'll be able to play in an improvisation that maybe learn this chord or kind of get the feel of how this melodic thing works. Hopefully getting more options musically because there'll be more in your bag of tricks I guess. So now, this month I'm doing this very specific practice for written pieces of music but when I warm up, I play freely. Or I'll just play tunes that I like, or I'll put something on YouTube that I kind of enjoy and maybe only heard once or twice, and I'll just play along with it. Like I'll play with a symphony orchestra, just jam with it. from a practical point of view, I think maybe only cogently related. I think it's important, At least for me it helps, to do all the different kinds of practicing. At least 3 times a day. In the morning. I have some meds to take so I can't eat f half an hour and then I'll do it again in the afternoon when I'm brain dead, sugar deprived, and then I'll do it again at night before I go to bed. And I think doing this helps things, I think, stick with you, but I think maybe that's another subject... A friend of mine, we did some duets last February and he would do every morning. He'd get up at five in the morning and practice and then go back to sleep. I don't think I could do that because once I practice I'm awake.

Pedro: Prepared guitar.

Susan: There was a time when I kind of, with my instrument, played almost only prepared guitar and in other words, only extended techniques, and now I'm doing my best to be able to play my instrument without extended techniques. Having said that, you mentioned the rock. With me it's a piece of slate I found in the alley behind the apartment I live in. I have 2 or 3 of them, and what I like doing with that, I take a tiny little screwdriver, one of those miniature screwdriver things, I will kind of go along diff parts of the rock and the ridges and things like that. When I think of this, I think I'm not producing this. This piece of slate or rock is telling its story and maybe I'm having a part in that by making that musical. Just like a string, or your instrument is telling its story. It needs you but you're not in control. You're a part of it. And I think that's an important distinction to make. $w /$ the extended techniques, a lot of times I will, when I practice that, which isn't as much as I should. Maybe after talking to you I'll go do it more but I try to find out what in musical way is possible to have some control over. When I do this, this happens. Not "it's an A note". The sound comes out, when I do this, that sound comes out. So, you have those things with you when you are doing those kind-of-extended techniques. Last week I did a gig where these great improvisers. I was kind of humbled, just how well they played their instruments and the extended techniques they used. One played the flute and the other one was a violinist. So, I did some things with harmonics and strings. Getting, 
playing open strings and getting harmonics and overtones. And that is something which I think is extended technique which you can work and have some control over. Say you're playing a guitar and you're not hitting a fret, of course I have no frets, you want this harmonic and it's at the eleventh fret. And you have the $12^{\text {th }}$ fret which is the octave, but when you get to the eleventh, it's very physically, I think, somewhat difficult for me to get that harmonic. So, the finger has to be in just the right place. You have to pick it just the right...the pick has to be in the right place. The finger has to be in exactly in the right place and it has to know when to get off the string, when to get on the string. Say you hit the string and you put your finger on it lightly to get that overtone, how do you do that? How do u do that with your pick? How do you do that and move to another note? How does that change things? So, all sorts of musical ways, and you can't control everything and part of the beauty is that same thing. It's not controllable. It's something that's not $100 \%$ up to you, that you're able to be surprised, right? I think the more control you have and the more you're able to - and I'm talking about control after I've already talked about being a partner with your instrument - I think the you as an individual control things the more exiting uncontrolled things can happen. Because you know your way around, you have some sort of map, physical map of how you do these things. And there's a lot of written music that's all prepared and it's the same skills for that. A friend of mine and I did a tune written by Eyvind Kang, it's all extended technique So the skills that I learned from playing on that piece, to some degree... I decided to use the same preparations or techniques in an improvisation.

Pedro: Long improvisations.

Susan: I don't know if I can answer that, because you're talking about time \{P: "I AM" (said the rude boy)\} S: and I think when ...time is flexible in some ways. Time marches on, and we get older, and we get old and die, and after a while we have to eat, but time in respect to music is a flexible. It's how we experience time. If you're in the dentist's office to remove your tooth 3 seconds can seem like... and if you're doing something you really enjoy that time, in other words... how you see time, how you experience time is fluid, it's flexible. I think during an improvisation if things are just magical, which sometimes they are, I don 't know that it's been 20 min or 30 min, or 15 or whatever. The thing with free improvisation is "how to start; when to start; when and how to end it" and I think that's kind of the unspoken thing, you know. "Ok, this is when it ends" so with time being so fluid I don't really think in that way.

If people seem like they're getting bored, the audience, when I'm playing solo I can hear the audience more, there are not a lot of other instruments going on. So, if people are starting to fidget in their seats, I just get the feeling that I'm boring them, then I move on. Pedro: Idiomatic and non-idiomatic

Susan: Well I guess I'm in between those 2 points of view. I know people who...some musicians like to, tend to philosophize and it's almost like, "we only play this and that, we don't do this, we're not doing that. So, I don't know if I can comment on it. For me personally, I don't feel like there is such a...I don't wanna use the words idiomatic or non-idiomatic cause those kind of create divisions, but w me I don't know if on a very deep level u can get beyond.... In other words, you're always informed, a tree is up there with its leaves and the sun, feeling the wind, but, it's fortified by its roots and as a musician my roots come out. If I'm improvising I don't forcefully control them or think about "oh! Now I'm going to play something country because I played country music for years or jazz..." we as musicians develop a skill set, and that's related to how we've developed as a musician. Maybe we'll play something for a while, then we'll be interested in something else, and then we'll be interested in this and that. and it all comes in to use. Especially your view on harmony and melody and counterpoint. What is appropriate, 
what sounds good to $u$ and what doesn't and of course that's all individual and it's a matter of opinion. And when ii hear people playing what they is non-idiomatic, it's like serialism. Serialism sounds non-idiomatic to me. So, I don't know. what are your thoughts on that? In some ways I think we have to break free of our roots in a way, u know, not let them necessarily control $u$, like, some people, they're playing blues and everything they do is gonna sound like blues because that's kind of basically all they like. Same w bebop or whatever. There's some musicians that I don't really hear a certain genre, and maybe instead of non-idiomatic maybe without genre maybe would be more appropriate. Like Fred Frith, he'll be playing something and then all of a sudden he'll play something that sounds like punk to me, or that kind of earthy kind of British rock, kind of punk sound, which predates punk music. It's older than me. With Pauline Oliveros, she changed things so much, there were some years when I spent a lot of time wher and a lot of time wher music. Her thing is about deep listening. Sometimes for me, deep listening, in certain hands sounds like a genre. Certain improvisers they have such control over their instruments and they're just playing such subtle things related to the space they're in, related to something else, that they don't sound like a certain genre to me. And when playing $w$ people like that, you approach things differently than $u$ do $w$ people who are playing notes melodies and chords a lot, in a free improv neither is better than another and neither is exclusive. So, non-idiomatic, idiomatic, I think it's like they say in Spanish mescla. It's a mix and It's a glorious mix, and we should be happy with that. We should be really excited that this whole thing, that there's this interaction between diff ways of approaching composition.

\section{Chefa Alonso - 09/09/2016}

Pedro: Habilidades da improvisação livre

Chefa: São Habilidades que se trabalha em coletivo... o trabalho, sobretudo, é duplo. Por um lado, tu tens que ir buscando tua própria linguagem - que realmente é a única coisa que funciona em uma improvisação coletiva. Quando você tem a sua linguagem, pode contar algo e contar à sua maneira, e isso é um pouco o que me interessa, mais isso só tampouco serve...podes fazer um bom solo autista. Podes ter a sua linguagem. Podes fazer um bom solo, mas quando o coloca a funcionar em um contexto coletivo, se você não desenvolveu também estas outras habilidades como a escuta, a concentração, a capacidade de decisão, se fosse só na esteira do "bom autista", não funcionaria porque soaria como algo sozinho e independente.

-A partir dessas afirmações, podemos pensar que, para Chefa Alonso, é importante desenvolver uma certa fluência no fazer sonoro. Ter uma "linguagem própria" é diferente de ter domínio de uma linguagem específica, comum a todos/as. Contudo, se no contexto da livre improvisação o elemento unificador é o sonoro, então podemos pensar que a fluência na concatenação de elementos sonoros, como parte da busca de uma '"linguagem própria”, coloca-se como um preparo importante para a prática da livre improvisação. Para Chefa Alonso, o exercício em coletivo também demanda o agenciamento em favor 
da comunicação. Por mais que o/a livre improvisador/a tenha a fluência necessária para concatenar elementos sonoros no devir de uma performance, a construção do fluxo sonoro depende do contato e interação com os demais elementos que cada participante expõe, caso contrário, o/a livre improvisador/a solo conseguirá “um bom solo autista”. (ANTAR)

Chefa: Portanto creio que o trabalho [é por um lado] um pouco pessoal de cada um... No sentido de trabalhar a fluência na concatenação de elementos sonoros no instrumento...

-Chefa diz que parte da sua preparação também tem a ver com esse lado pessoal: "trabalhando algum material "raro" ou algo que lhe interessasse no momento". (ANTAR)

Chefa: Também colocava para tocar no aparelho de som algum solista. Peter Kowald, por exemplo, que é um contrabaixista alemão que faz improvisação livre. Eu ligava o som e tocava com ele para ver como funcionava. Por isso creio que são as duas coisas. Você tem que trabalhar o seu solo e tem que trabalhar em coletivo para poder desenvolver tudo o que é necessário para que a improvisação funcione sempre.

- Chefa diz então que é preciso preparar-se para ter fluência com o instrumento, e utilizarse disso no coletivo. Podemos pensar que a "fluência própria" de cada participante de uma seção de livre improvisação, terá ressonância do coletivo na medida em que o treinamento com elementos sonoros outorga-lhe "segurança" nas ações, pode mais insólitas que elas possam parecer. Já no que diz respeito ao treinamento com gravações de outros músicos/musicistas, podemos pensar que se tratam de momentos em que Chefa põe à prova certos elementos dela, em reação ao que a gravação esteja sugerindo. Assim, o treinamento não só se direciona à fluência na elaboração e concatenação de elementos sonoros, mas também explora a pronta reação a estímulos externos. Uma maneira de se preparar para interagir com mais soltura, numa seção com músicos/musicistas "de verdade". (ANTAR)

Pedro: Práticas extramusicais.

Chefa: A improvisação livre tem muito das normas sociais da boa educação. Da pessoa que respeita ao outro e que o tem em conta. Certas normas fundamentais como "eu tenho algo a dizer e o digo. Tenho que encontrar "o espaço" [ela diz o buraco] para dizê-lo, mas você também tem algo a dizer, então tenho que deixar também o espaço para que possa dizê-lo e eu possa responder a isso. Eu creio que a regra básica da improvisação livre é a democracia e o respeito pelo outro.

Pedro: Contingências.

Chefa: Eu quando toco ou quando vou começar uma improvisação ou tocar, isto é o que me importa. Estar neste momento. Não sei até que ponto influi, sua situação atual, sua situação política, amorosa, relações de amizade... eu creio que eu consigo. Creio que a improvisação é um pouco isso. Estar neste momento enquanto isso só tenho alma para escutar o que está se passando, escutar a mim mesma para ver o que disse. 
- Para Chefa Alonso a imersão no momento presente possibilita a fluência sonora, deixando de lado as preocupações externas da vida. (ANTAR)

Chefa: O que se passa é que este momento que se acurralado, de todos os seus problemas políticos, conseguir seu próprio interesse. Como todas as dificuldades tanto aqui como no meu país, quando chega o momento de tocar eu estou feliz. Todos os meus problemas param. Chega o momento de algo que quero, que gosto. Há quem me pergunte, "mas você não fica nervosa de tocar diante das pessoas?"...

- Chefa diz que a maioria das outras coisas, externas à música, é o que a deixam nervosa... e tudo isso some na hora de tocar, pois o tocar é o que a deixa feliz. Aqui podemos pensar na relação entre a vida civil e vida musical. Para Chefa, o momento de criação grupal é um momento de abstração da realidade material e imersão na socialização do fazer sonoro. Esse momento também é verdadeiro na medida em que nele as relações sociais se efetivam, pois, é pela colaboração entre os/as participantes que se gera o fluxo sonoro. (ANTAR)

Miguel: Sobre tocar junto com gravações de outros musicistas, não há uma via dupla.

Chefa: Claro que não há, mas creio que é um bom aprendizado. Eu fazia isso mais quando estava começando.

- Chefa se refere a esse momento de training com cds, como um período de estudos anterior à rotina de tocar com outros/as músicos/musicistas. Depois de entrar no “circuito”, já não precisou "treinar” com cds. (ANTAR)

Chefa: Agora não faço porque toco diretamente com músicos, mas quando não conhecia muita gente e ainda estava pesquisando meus gostos... eu creio que é um bom conselho. Um músico ou dois. Melhor poucos porque, como não há interação com você... Peter Kowald me serviu muito porque tem um disco de solos que chama Was Da Ist. Cada faixa é o desenvolvimento de um material muito concreto e é algo que se ouve muito bem, que material trabalha e como o desenvolve. Neste sentido é muito claro. Ajuda muito a observar este material que parece que está cortando arvores no bosque, (faz com a voz. um som granulado fricativo com crescendos acentuados e piano súbitos em ciclo), e vai caminhando. Chefa se refere aos materiais que podem ser ouvidos no cd. Esse material em específico parece arvores sendo cortadas. Daí ela descreve seu treinamento ouvindo esse material sonoro proposto por Kowald. São peças curtas, entre 3 e 5 minutos. Isto te obriga também a buscar outras coisas e quando você está sozinha e não tem este estímulo, talvez esses novos materiais não apareçam. Acho que ela quis dizer isso. Que por meio do training de interação com o cd, ela consegue descobrir sons inusitados que dialogam com os sons de Kowald.

Miguel: Como se fosse um exercício de iniciação

Chefa: Exatamente!

Pedro: Música escrita e a formação musical tradicional.

Chefa: Quanto mais você sabe, melhor. Tive uma formação acadêmica. Estudei em conservatório, estudei escalas, partituras, etc. agora, eu como professora, muitas vezes 
tenho isto que você disse, tenho gente com uma formação instrumental impressionante que tem um nível do caralho [sic.], ou seja, conseguem tocar muito bem, e gente que vem da rua, que são autodidatas e que não leem, e gosto muito de juntá-los. Da mesma forma que gosto de juntar pessoas de disciplinas diferentes é ótimo. Não só músicos, mas outras pessoas, porque efetivamente é o que você disse. Os dois mundos são muito ricos e um alimenta ao outro. Portanto o que planejo para mim e em todas as minhas propostas é possível que convivam estas duas personalidades. Minhas propostas podem ser feitas igualmente por alguém que tem um grande nível instrumental, e sabe ler, e sabe tals, $e$ sabe escalas e pessoas que não...eu trabalho sobretudo com o som e um pouco de interação e escuta, esse tipo de coisa. E de fato, o que mais se dá no ensino tradicional, é essa base nas escalas, no pensamento tonal, etc... Eu estou um pouco cansada disso. Não digo que não gosto. Em determinado momento eu também estudei escalas, às vezes, mas isso é o que tem o ensino normal. Com meus alunos que sabem tudo isso, eu procuro que eles se esqueçam disso, e pesquisem mais o som. Assim, minhas propostas eu as pensei para que possam ser realizadas por pessoas com muito nível técnico e também pessoas com pouco nível técnico. Inclusive não músicos... dançarinos, poetas, pessoal de circo, da cena... acho que isso enriquece todos, aprendemos muito mais assim.

Miguel: Resistência de quem tem boa leitura.

Chefa: Os que vem a minhas oficinas não (nos meus ateliers) Normalmente aqueles que tem muita técnica e tals, não se interessam por minhas oficinas. - você toca bem tecnicamente mas tem alguém que não toca bem mas tem muito mais expressividade do que você, assim, todos nos alimentamos. Todos temos que aprender com todos. "Em minhas oficinas é tudo anticompetitivo"

Miguel: Tenho muitas vezes a sensação de que o excesso de técnica e conhecimento aprisiona a pessoa e é nesse ambiente da improvisação livre que buscamos a liberdade, justamente....

Chefa: De fato, nas minhas aulas tem muita gente com formação clássica, mas estão frustrados porque não há conexão entre sua alma de musico e o instrumento que tocam. Também por esse ensino convencional, frustrante e castradora...pelo menos no meu pais, nos conservatórios, é uma técnica que está longe das necessidades expressivas do que estudam [...]. Tem gente que vem a minhas oficinas e não quer tocar o instrumento que eles aprenderam no ensino tradicional. Eu lhes digo que não precisa começar tudo de novo, que está bem saber tocar o instrumento. Que é uma questão de liberdade. Que se trata de saber administrar essa técnica tão boa que eles têm, ao serviço daquilo que eles querem tocar... Nos conservatórios não tocamos música contemporânea. E sobretudo, que eu creio que seja fundamental, nos lugares em que se ensinam disciplinas artísticas, não se pode esquecer da criação, da criatividade, e se esquecem. Nos conservatórios se esquecem. Não estimulam às pessoas a compor, criar suas próprias...não. São todos como se fossem maquininhas de interpretação de um repertório muito concreto. A "música", a música clássica. Bem, é uma música europeia de três séculos concretos ou dois. E a música é muito maior e muito mais, não? O que mais me deixa brava... que na música, é considerado um bom musico aquele que toca muito bem Beethoven... Mas não podemos esquecer que um pintor também aprende copiando grandes pintores, mas um pintor se é importante é pelo que ele põe de novo, de adição ao mundo, não? Por outro lado, na música, toca muito bem quem toca Beethoven. Beethoven está morto há quanto tempo? Um bom músico é aquele que muda o mundo por sua forma de entendê-lo e entender a música. E aí seguimos jogando.

-Chefa reclama que nos conservatórios e escolas tradicionais o ensino se concentra na repetição de um conjunto de obras e se esquece de estimular o aluno a criar coisas novas... 
Para ela, "o bom músico é o que muda o mundo por sua maneira de entende-lo e entender a música", e não aquele que repete bem Beethoven. (ANTAR)

Pedro: $O$ que é uma boa improvisação?

Chefa: Creio que uma boa improvisação tem que ter fluidez. Deve ser perceptível a interação entre os músicos. Não que sejam discursos independentes, mas que realmente é uma boa conversa e quiçá que passe, digamos, por paisagens ou por momentos diferentes. Que não seja monótona ou que esteja o tempo todo a mesma coisa. Claro que isso é muito pessoal, depende do gosto pessoal de cada um. Acho que ela quis dizer: $O$ que pode ter funcionado para mim, não significa que funcionou pra o/a outro/a. Ela se refere a esse caráter ambíguo que tem a livre improvisação... por um lado pode ser muito boa pra uma das partes envolvidas e também muito ruim pra outra das partes. Uma improvisação pode ser boa porque funcionou para mim, mas outra pessoa pode falar que o resultado final não the interessou. Acho que o fundamental é que a improvisação caminhe, ou seja, que de pra perceber a fluidez, como se fosse que não estivera sendo feita pelos músicos, mas que só apareceu!

-Para Chefa é importante: Fluidez na concatenação de elementos sonoros (plano individual). Interação e conversa (plano grupal). Assim se obtém: renovação dos elementos e construção de momentos sonoros diferentes. A sensação que ela busca descrever, me parece, é de espontaneidade. "como se fosse que não estivera sendo feito por alguém, mas que apareceu e caminha". Para Chefa, "essa sensação é uma boa sensação"... ou seja, uma boa improvisação. (ANTAR)

Pedro: O que você considera uma improvisação longa?

Chefa: Normalmente não quero que supere os 50 minutos. Tanto por nós que participamos da improvisação como pelo público porque este tipo de música normalmente exige também um público muito especial e atento. Eé um esforço também para o público estar ali pendente de tudo que está passando. Creio que em improvisações muito longas chega um momento em que as pessoas perdem a atenção ou o interesse. Então normalmente, quando há concertos, não mais de 50 minutos. Creio que aí está um pouco o limite da atenção do público e também dos músicos. Também é cansativo improvisar, ou seja, estar compondo a todo momento por muito tempo. Eu creio que 50 minutos é o máximo.

Pedro: Alternância entre percussão e saxofone.

Chefa: tocar por 40' só saxofone é duro. Para a mão que sustem o instrumento, para a boca, para tudo, para a cabeça. Então como eu também toco outros instrumentos, sobretudo a percussão que me encanta também a nível composicional e improvisacional, gosto muito de alternar os dois instrumentos.

Pedro: Estratégias de preparação para improvisações mais longas.

Chefa: Sim, sim, inclusive para seções longas e curtas. Em geral, me interessa muito mais tocar com pessoas, mas às vezes me propõe tocar solo, eu me preparo. Ainda há muita improvisação mas preparo a estrutura, a ordem, digo: com sax ou com percussão, a alternância. E preparo também, às vezes, um tipo de material sonoro que me interessa, e por vezes que posso usar ou não, mas na cabeça tenho "bom, a primeira parte de sax vou fazer uma coisa mais rítmica ou um material mais rugoso ou o que seja e mudo para na seguinte pensar de outra maneira. E o mesmo com a percussão. As vezes tenho uma 
ideia na cabeça como "terra". Como um som de terra. O que me sugere a "terra" dai então faço coisas que me lembram a terra.... ou na percussão posso pensar em motes como "ar" ou "campana"... às vezes são coisas simples mas quando improviso solo sempre estruturo. Eu sou uma amante das estruturas. Gosto muito das estruturas. Porque creio que dá muita liberdade e ao mesmo tempo colocam ordem que também é bom. Facilita a escuta e facilita também a criatividade. Eu sou a favor das estruturas. Nem sempre. Também toco sem estrutura nem nada, mas de vez em quando também gosto de estruturar um pouco.

- Chefa considera que estruturas ajudam a organizar a improvisação (em um primeiro momento). Porém durante o concerto se têm a liberdade de não mais considerar a estrutura. (ANTAR)

Miguel: Em grupo também?

Chefa: Com músicos, normalmente não. Normalmente já tocamos, mas trabalho muito com poetas, fazendo improvisação. E, claro, com poetas há estrutura porque há a ordem de leitura dos poemas, por exemplo, e é algo que me encanta porque há um trabalho prévio. É improviso, mas também é um trabalho de composição, mas não uma composição tradicional em que eu pego um pentagrama e desenho notinhas. Não me importo com "notinhas", mas sim o que este poema me sugere. Daí então eu faço também algo como um plano de sonoridade, atmosferas, ambientes. Então há uma parte de composição, porque tenho na cabeça uma ideia para fazer e há também muita improvisação e também depende do momento e posso mudar coisas e tudo isso, mas quando trabalho isso com poesia é uma mescla boa de composição e de improvisação livre. Creio que isso funciona muito bem também.

Pedro: Maiores dificuldades na improvisação e preparação para improvisar.

Chefa: Não sei. Improvisação coletiva ou solo? A que se refere?

Pedro: Principalmente coletiva.

Chefa: Como eu já não me preparo neste sentido para uma improvisação coletiva, mas quando preparava o que achava mais difícil?...

Pedro: Nos seus ateliês, que dificuldades os seus alunos mais apresentam?

Chefa: $O$ que eu mais encontro ensinando os alunos, o que mais lhes custa é o silêncio, calar-se. Há sempre uma angústia, uma ansiedade de tocar, tocar, tocar, tocar, e é normal. Acontece com todos nós. Porque, bom, a gente fica provando coisas, explorando e tals... E essa ansiedade de tocar te leva a não escutar. Então aí eu digo ao aluno: para! Para um momento de tocar e escuta, porque às vezes as pessoas tocam angustiadamente porque geralmente não têm uma ideia. É só tocar por tocar e isso não leva a nenhum lugar. $O$ melhor que pode fazer quando não tem ideias é calar-se porque os companheiros vão te dar ideias, com certeza! Então cale-se, escute e olhe o que está se passando, e pense "o que posso inserir que vá melhorar o todo". Senão cale-se. Porque também é bom ficarmos calados. O que posso colocar que melhore ou que me apetece em relação ao que está soando. A partir dessa atitude, a coisa vai caminhando. Eu creio que a princípio o mais difícil é calar-se, ou seja, admitir que o silêncio está muito bem e faz parte da música. O contrário também é difícil. Ou seja, tomar decisões como "agora vou eu, vou contar algo, que tem relação com o que está passando. Pois isso também é difícil e ficamos pensando: "entro ou não entro..." Tome a decisão e anda, se arisca! Se sair mal e não funcionar, bem, a vida é assim. Nem sempre é êxito, êxito, exito. Muitas vezes as coisas não funcionam. Não tem problema. E outra coisa que lhes custa são os finais. Os finais também precisam ser ouvidos. Eles aparecem. Não os tem 
que fazer. Às vezes você tem que fazer, mas às vezes não precisa fazer mais do que escutálos. Às vezes há um final, e porque segues tocando? Mas isso também tem de ser aprendido. É normal. Deve-se ter também o ouvido para se dar conta de que acabou. Às vezes é muito obvio mas deve-se aprender a escutar. Isto também é uma dificuldade importante. Eu creio que são as três maiores dificuldades.

Pedro: Alguma outra coisa que gostaria de dizer?

Chefa: Creio que é importante e tento sempre dar confiança para as pessoas que às vezes estão inseguras porque é um caminho muito inseguro e muito incerto. Porém, agora é menos inseguro, porque há mais improvisadores, há uma cena de improvisação em muitos lugares. Mas quando eu comecei no meu país, na Espanha, não havia absolutamente nada, nesse tempo eu não sabia se eu era esquisita pra caralho porque eu tocava esquisito... Contudo, eu creio que é importante que as pessoas confiem em si mesmo, no que pede o corpo, no que pede a cabeça. Isso sempre é verdade. Ainda que o mundo estiver em contra disso e sejas criticado. Se você tem alguma tendência a fazer algum tipo de música, - música pode ser até um tipo de dança, algum tipo de arte-, por mais que ache estranho, por mais que pareça esquisito, corre em direção disso, porque isso é que é verdade. Neste sentido animal. Há pessoas que pensam que é difícil, que é um caminho muito longo, mas eu creio que a liberdade para o que estamos aqui. A liberdade é fundamental. Então devemos animar o pessoal a que não tenha medo. Que vá. 